\title{
Open-end Organizational Structures and Limits to Arbitrage*
}

\author{
Mariassunta Giannetti \\ Stockholm School of Economics, CEPR, and ECGI \\ Bige Kahraman \\ Saïd Business School, University of Oxford
}

We provide evidence that open-end structures undermine asset managers' incentives to attack long-term mispricing. First, we compare open-end funds with closed-end funds. Closed-end funds purchase more underpriced stocks than open-end funds, especially if the stocks involve high arbitrage risk. We then show that hedge funds with high share restrictions, having a lower degree of open-ending, also trade against long-term mispricing to a larger extent than other hedge funds. Our analysis suggests that open-end organizational structures are not conducive to long-term risky arbitrage.

Keywords: Limits to Arbitrage, Flow-performance Sensitivity, Organizational Structure, Market Efficiency

JEL Classification: G12, G23

\footnotetext{
*An earlier version of this paper was circulating under the title "Who trades against mispricing?". We would like to thank Andrew Karolyi (the editor), two anonymous referees, Yakov Amihud, Andrew Ang, Suleyman Basak, Martin Cherkes, Nick Barberis, Darwin Choi, Josh Coval, Sudipto Dasgupta, Francesco Franzoni, Greg Duffee, William Goetzmann, Gur Huberman, Charles Jones, Shimon Kogan, Xuewen Liu, Stefan Nagel, Alberto Plazzi, Jeff Pontiff, Tarun Ramadorai, Ronnie Sadka, Neng Weng, Avi Wohl and seminar participants at the NBER Market Microstructure Meeting, the University of British Columbia Summer Conference in Finance, the European Finance Association, the Financial Intermediation Research Society, the Workshop on Financial Intermediation and Risk at the Barcelona GSE Summer Forum, the $6^{\text {th }}$ Annual Hedge Fund Conference in Paris, the Paul Woolley Center for Capital Market Dysfunctionality Conference, the Humboldt University/ESMT Conference on Asset Management, the 2014 Jerusalem Finance Conference, the 3rd Luxembourg Asset Management Summit, HKUST, the Swiss Finance Institute at the University of Lugano, the Shanghai Advanced Institute of Finance at Jiaotong University, the Singapore Management University, the Duisenberg School of Finance, the Stockholm School of Economics, and Humboldt University for helpful comments. We thank Vikas Agarwal, Wei Jiang, Yuehua Tang, and Baozhong Yang for sharing their hedge funds data and Andreas Johansson, Mats Levander and Viktor Thell for research assistance. Giannetti acknowledges financial support from the Jan Wallander and Tom Hedelius Foundation and the Bank of Sweden Tercentenary Foundation. All errors are our own. Send correspondence to: Mariassunta Giannetti, Stockholm School of Economics, PO Box 6501, Sveavagen 65, S 11383 Stockholm, Sweden. E-mail: mariassunta.giannetti@hhs.se.
} 
Do open-end organizational structures prevail because they are the most efficient, as argued by Fama and Jensen (1983)? Or, as Stein's (2005) model shows, the degree of open-ending in the market can be socially excessive because open-end organizational structures discourage asset managers from trading against mispricing? This paper aims to contribute to this debate by providing evidence that open-end structures indeed weaken managerial incentives to trade against mispricing.

The seminal paper of Shleifer and Vishny (1997) describes the mechanism through which open-end structures can be a serious impediment to exploiting profitable trading opportunities. Asset managers invest other people's money. Fund investors typically lack specialized knowledge to evaluate an asset manager's strategy and may simply evaluate the manager on the basis of his recent past performance. If the long-term mispricing that a fund manager is exploiting fails to converge in the short run, investors may decide that the manager is incompetent and refuse to provide him with more capital, and even withdraw some of it. To avoid encountering such bad scenarios in the future, asset managers may neglect mispricing for which convergence to fundamentals is unlikely to be either smooth or rapid. Only asset managers whose flows are less sensitive to performance may thus be willing to trade against long-term mispricing.

To test this hypothesis, we start by contrasting the trading behavior of openand closed-end funds. Open- and closed-end funds are subject to similar regulations, but differently from open-end funds, closed-end funds' assets under management do not depend on investor flows. If the sensitivity of flows to performance undermines managers' incentives as described by Shleifer and Vishny (1997), we expect closedend funds to be more inclined to trade against long-term mispricing. We then extend our analysis to hedge funds, and exploit that hedge funds often impose share 
restrictions constraining withdrawals. Share restrictions decrease the funds' flowperformance sensitivity (Hombert and Thesmar 2014). We thus expect hedge funds with high share restrictions to be more inclined to trade against long-term mispricing than hedge funds with low share restrictions. Finding that any differences between closed- and open-end funds are reproduced between hedge funds with high and low share restrictions would provide an independent validation of our hypothesis.

For our tests, it is important to identify types of mispricing for which arbitrage is risky and can be expected to be profitable only in the long run. Forced sales of distressed funds can give rise to fire sales that cause a dramatic drop in stock prices. Fire sales have been shown to bring about long-lasting mispricing of financial assets, persisting for up to two years (Coval and Stafford 2007; Duffie 2010). Uncertainty on the timing of convergence can significantly reduce short-term returns from investing in fire sale stocks making this type of mispricing suitable for our tests.

As additional evidence, we use mispricing that arises from noise traders' irrational enthusiasm for certain stock characteristics. A common prediction of behavioral models is that shifts in noise traders' demand induce mispricing in stocks with similar characteristics (Daniel, Hirshleifer, and Subrahmanyam 2001; Barberis and Shleifer 2003). This type of mispricing suits our conceptual framework as the timing of convergence to fundamental value is uncertain due to the unpredictable nature of shifts in noise traders' demand.

We find that closed-end funds are more inclined to buy undervalued stocks than open-end funds. The difference in the net purchases of closed- and open-end funds in fire sale stocks is about half of the standard deviation of all trades, indicating that the effects are not only statistically, but also economically significant. Differences in trading behavior are more pronounced for stocks with high arbitrage 
risk (such as small stocks and stocks with highly volatile returns), as predicted by Shleifer and Vishny (1997). Similarly, hedge funds with higher share restrictions invest more in undervalued stocks compared to hedge funds with lower share restrictions. Consistent with the notion that closed-end structures exploit long-term risky mispricing, we find that closed-end funds' alpha is considerably higher than open-end funds' alphas $(0.23 \%$ versus $-0.06 \%)$. Similarly, hedge funds with share restrictions above the median have nearly $0.10 \%$ higher monthly alpha than hedge funds with share restrictions below the median.

We provide evidence on the mechanism driving our results by studying crosssectional differences across funds. In particular, we show that differences between open- and closed-end funds are more pronounced for open-end funds with higher flow-performance sensitivity. We perform these tests by estimating open-end funds' flow-performance sensitivity as well as by using open-end funds' characteristics (such as managerial tenure and institutional investment in the fund), which are related to the sensitivity of flows to performance. These tests confirm the relevance of managerial incentives arising from the sensitivity of flows to performance.

Not only do our findings emerge across different classes of asset managers, but they also survive a battery of robustness checks that aim to rule out that certain fund characteristics, potentially correlated with the fund's organizational structure, drive our findings. For instance, we find that fund managers co-managing open- and closed-end funds trade against mispricing more in their closed-end funds than in their open-end funds indicating that our results are not driven by differences in managerial ability. In addition, our results are robust if we compare a matched sample of openand closed-end funds with similar styles indicating that differences in trading styles are unlikely to drive our findings. Finally, open-end funds appear less likely to 
purchase fire sale stocks even when we control for various measures of the funds' financial slack, confirming the hypothesis that the incentives arising from funds' organizational structures matter. Taken jointly, our tests highlight that organizational structures lowering the sensitivity of flows to performance strengthen asset managers' incentives to trade against mispricing.

Our paper is related to a growing literature that explores asset managers' trading strategies. Existing literature provides mixed evidence on the extent to which institutional investors trade against mispricing. For instance, Cella, Ellul and Giannetti (2013), Edelen, Ince and Kadlec (2013), Greenwood and Nagel (2011), Mitchell, Pedersen, and Pulvino (2007) and Brunneimeir and Nagel (2004) find that institutional investors, including hedge funds, trade in a way that accentuates mispricing. Akbas, Armstrong, Sorescu, Subrahmanyam (2014), Cao, Chen, Goetzmann, and Lian (2013), Kokkonen and Suominen (2015), however, show that hedge funds tend to correct mispricing. We consider differences in institutional investors' degree of open-ending and show that open-end organizational structures act as an impediment to long-term risky arbitrage. These results contribute to the debate between Fama and Jensen (1983) and Stein (2005) on the efficient organization of the asset management industry. We also highlight the role of share restrictions on hedge funds' tendency to attack mispricing.

Another strand of literature explores the effects of the liability structure on funds' performance and investments in illiquid assets. Aragon (2007) and Agarwal, Daniel, and Naik (2009) find that hedge funds with high redemption restrictions have higher returns, presumably because they are able to invest in illiquid assets and obtain an illiquidity premium. Cherkes, Sagi, and Stanton (2008) show that the closed-end 
fund discount increases in high VIX periods, suggesting that closed-end funds are exposed to illiquid assets.

Controlling for stock liquidity, we highlight the effect of open-end structures on funds' tendency to trade against long-term mispricing. A number of papers (e.g., Tetlock 2008; Bloomfield, O'Hara and Saar 2009) point out that stock liquidity and the extent of mispricing are not equivalent. Importantly, stocks may be liquid and also mispriced. Our tests indicate that closed-end structures can help overcome arbitrage risks, which differ from the transaction costs associated with illiquidity (Pontiff 2006).

The remainder of this paper is organized as follows. Section 1 provides background information and describes the data sources. Sections 2 and 3 describe how funds with different organizational structures trade against mispricing. Section 4 concludes.

\section{Institutional Background and Data Sources}

Most investment vehicles, including open-end mutual funds and (most) hedge funds, have an open-end structure. A large literature documents that, as a consequence, funds' assets under management depend on the funds' past performance. ${ }^{1}$ This is the case not only because asset managers are funded with redeemable claims, which expose them to withdrawal risk, but also because weaker performance tends to translate in less new investments. In contrast to open-end funds, closed-end funds have a closed-end structure. Hedge funds with share restrictions have a lower degree of open-ending because the restrictions limit investor redemptions. Below we discuss the institutional features of different organizational structures and describe our data sources.

\footnotetext{
${ }^{1}$ Evidence is pervasive for open-end funds (e.g, Sirri and Tufano 1998; Huang, Wei, and Yan 2007; Spiegel and Zhang 2013) as well as for hedge funds (Goetzmann, Ingersoll, and Ross 2003; Agarwal, Daniel, and Naik 2004).
} 


\subsection{Closed-end and Open-end Funds}

Open-end funds' assets under management depend on investors' decisions to invest or redeem, that is, on investor flows. By contrast, closed-end funds are professionally managed investment companies that typically sell a fixed number of shares at one time (in an initial public offering), after which the shares trade on a secondary market. The vast majority of closed-end funds does not accept new investments. $^{2}$ Closed-end funds also have no obligation to redeem investors' shares.

Contrasting closed- and open-end funds provides a useful setting to explore the role of the sensitivity of flows to performance in constraining long-term risky arbitrage. Closed- and open-end funds are regulated primarily under the same sections of the Investment Company Act of 1940 and are subject to SEC registration and the Securities Act of 1933 and the Securities Exchange Act of 1934. Differently from open-end funds, closed-end funds are allowed to borrow (Almazan, Brown, Carlson, Chapman 2004), but in practice only a few closed-end funds use leverage (Dimson 2002). Also, while closed-end funds are allowed to invest in asset classes that cannot be liquidated in less than one week, we explore their differential behavior in US listed stocks, which are unlikely to incur this constraint.

We obtain data on the entire universe of US closed-end funds from Lipper Inc., distributed by Thomson Reuters, and from Morningstar Direct. Lipper and Morningstar have similar coverage. If a fund appears in both Lipper and Morningstar,

\footnotetext{
${ }^{2}$ A minority of closed-end funds is continuously offered (about $4 \%$ in our dataset). These funds are excluded from our sample. In addition, closed-end funds occasionally issue and repurchase shares as any other listed company (Khorana, Wahal, and Zenner 2002). Since the timing of share issues and repurchases is under managerial control, any relationship between performance and asset under management arising from the change in shares outstanding is not expected to weaken managerial incentives to trade against mispricing. As shown in column 1 of Table IA.1 of the Internet Appendix, controlling for the change in closed-end funds' shares outstanding does not affect our findings.
} 
we use data from Lipper. In this way, we construct a survivorship-bias-free dataset that provides information on quarterly stockholdings and a variety of other fund characteristics, such as monthly returns, total net assets under management (TNA), annual fees, and allocation schemes. We complement this data with S\&P Capital IQ, which provides information on closed-end funds' liabilities (if any).

We obtain the correspondent information on characteristics and quarterly stockholdings for open-end funds from the CRSP Survivorship Bias Free Mutual Fund Database and the Thomson Reuters Mutual Fund Holdings database, respectively. We further obtain information on open-end funds' characteristics, such as cash, institutional investment in the fund, managerial ownership and governance, from Morningstar Direct. During our sample period, many mutual funds have multiple share classes. Since each share class of a fund has claims to the same portfolio holdings, we aggregate all the observations at the fund level. As is common in the literature, for qualitative fund attributes, such as objective and year when the fund was first offered, we use the attributes of the oldest share class; for the total net assets under management, we sum the net assets of all share classes, and take the TNA-weighted average for the rest of the quantitative attributes (e.g., returns).

We exclude index funds by removing funds that are identified by CRSP or Morningstar as index funds and by screening funds' names and eliminating any fund whose name contains the word "index". Since closed-end funds tend to be smaller than open-end funds, to have open- and closed-end funds of comparable size, we exclude open-end funds in the top TNA quintile. In the fire sale tests, we also exclude open-end funds with extreme flows as defined in Subsection 2.2.

Finally, we obtain information on stock characteristics and prices from COMPUSTAT and CRSP, respectively. 
Our tests rely on two samples. The first sample (holdings sample), used in the fire sale tests, allows us to focus on quarterly changes in funds' stockholdings. Holdings data for closed-end funds are available from January 2004 to December 2014. For consistency with previous literature, we eliminate the holdings of open- and closed-end funds with TNA less than 1 million or that report less than 10 stock holdings.

The holdings sample includes a total of 436 unique closed-end funds and 1,196 unique open-end funds. While we have fewer closed-end funds in the earlier part of the sample (for instance, from 2004 to 2007, we have fewer than 100 closedend funds per quarter), there is a steady increase in the number of closed-end funds over the sample period. ${ }^{3}$ The coverage of open-end funds' holdings is high throughout the sample with the number of open-end funds in a given quarter ranging from 420 to 687. To mitigate concerns that differences in coverage may drive our findings, we perform robustness tests in which we match each closed-end fund in our sample to an open-end fund.

The second sample (returns sample), used in the tests on sentiment-driven mispricing, does not require holdings data, but only funds' monthly returns. Data on monthly returns are available for both closed- and open-end funds starting from January 1990 to December 2014. To focus on a more homogeneous set of funds, this sample includes only US based funds specialized in domestic equity. Unlike the holdings data, data coverage on closed-end fund returns is high for most of the sample period. ${ }^{4}$ In total, there are 406 unique closed-end funds and 2,136 unique open-end funds in the returns sample.

\footnotetext{
${ }^{3}$ For instance, we have between 120 and156 closed-end funds per quarter in 2008 and about 190 closed-end funds at the end of 2010. The maximum number of closed-end funds is 253 in March 2012.

${ }^{4}$ The mean number of closed-end funds in the return sample is 155; minimum 88 and the maximum 228.
} 


\section{[Insert Table 1 here]}

Table 1 reports the descriptive statistics for the closed- and open-end funds in the holdings sample. Panel A summarizes the funds' main characteristics. The average size of the open-end funds in our sample is similar to that of the closed-end funds. As expected, open-end funds have a greater portfolio overlap with distressed funds. Open- and closed-end funds also charge similar annual fees. On average, closed-end funds have a leverage of $6.8 \%$, while open-end funds hold $2 \%$ of their TNA as cash.

Panel B in Table 1 compares the main characteristics of the stocks held by closed- and open-end funds. We confirm the conjecture that closed-end funds hold more illiquid stocks (e.g., Cherkes, Sagi and Stanton 2008); to our knowledge, our paper is the first to provide direct evidence on closed-end funds' preference for illiquid assets using holdings data. Moreover, closed-end funds invest more in value stocks and engage less in momentum trading.

\subsection{Hedge Funds}

We also explore the effects of hedge fund share restrictions. Hedge funds are organized on an open-end basis. However, at their inception, hedge funds can impose share restrictions that limit investors' ability to redeem by requiring advance notification (redemption notice period) or by restricting redemptions to predetermined periods (payout period). Also, some hedge funds have lock up periods that impose a minimum investment time on new investors. Because of share restrictions, hedge funds' degree of open-ending varies.

Hedge funds are subject to much more flexible regulation than open- and closed-end funds, which allows them to use leverage more aggressively and take short 
positions. They also have fee structures that provide them with steep incentives. For all these reasons, hedge funds are considered to be closer to the ideal of "rational arbitrageurs" than any other class of investors (Brunnermeier and Nagel 2004). Therefore, hedge funds may be more inclined to trade against mispricing than openand closed-end funds even in the absence of share restrictions. However, since share restrictions decrease hedge funds' flow-performance sensitivity (Hombert and Thesmar 2014), we expect hedge funds with high share restrictions to take larger positions in mispriced securities compared to hedge funds with low share restrictions. Hedge funds thus provide an independent test for the relevance of open-end structures for asset managers' propensity to trade against mispricing.

We obtain information on hedge funds' characteristics including returns, assets under management and share restrictions from Lipper Tass, CISDIM/Morningstar, and Hedge Fund Research. These three commercial datasets provide information on largely different subsets of hedge funds (Agarwal, Fos and Jiang 2013). We exclude duplicates of any funds that appear in more than one dataset; for funds reporting to more than one commercial dataset, we use Lipper Tass or, if missing, CISDIM/Morningstar. Commercial datasets report defunct funds starting from 1994. Following the literature (e.g., Agarwal, Daniel, and Naik 2009), we therefore exclude observations prior to 1994 to mitigate a potential survivorship bias.

The hedge fund datasets do not provide information on the hedge funds' stock holdings, which is essential for some of our tests. We obtain hedge funds' quarterly stockholdings at the management company level from Thomson Financial 13F. Since Thomson Financial $13 \mathrm{~F}$ and the hedge funds' databases provide no common identifiers, we obtain the match between hedge funds' commercial databases and $13 \mathrm{~F}$ quarterly ownership from Agarwal, Jiang, Tang and Yang (2013) and Agarwal, Fos 
and Jiang (2013). The match includes only management companies that are relatively "pure-play" hedge funds and does not include full-service banks whose investment arms engage in hedge fund business. We aggregate the hedge funds data to the management company level for the tests using the holdings data (hedge funds' holdings sample).

The hedge funds' holdings sample includes a total of 355 unique management companies from January 1994 to December 2014. The number of management companies varies over time. It ranges from 35 to 176 until 2004, increases up to about 220 between 2005 and 2007, and gradually decreases to 135 by the end of the sample period.

As in the case of closed- and open-end funds, we construct a second sample for the tests on sentiment-driven mispricing (hedge funds' returns sample), which only requires data on hedge funds' monthly returns. We perform these tests at the fund level and restrict the sample to funds specialized in US equity because we explore funds' exposure to different portfolios of US equity. In particular, we select hedge funds with the following styles: long/short equity and multi-strategy hedge funds from Lipper Tass; equity hedge funds, excluding the ones specialized in a particular sector from Hedge Fund Research; and long/short equity, equity market neutral long-only equity hedge funds from CISDM. As a result, the hedge funds' returns sample includes 3,336 unique hedge funds.

[Insert Table 2 here]

Table 2 reports descriptive statistics for the hedge funds' holdings sample. Panel A summarizes the duration of each type of share restrictions. We approximate the payout period assuming that fund investors have uniformly distributed liquidity shocks. Thus, on average, an investor will have to wait 45 days before being able to 
redeem her capital if the hedge fund has a quarterly (90 days) payout period. Following Agarwal, Daniel, and Naik (2009), we measure share restrictions by adding up the number of days in the lock up period, the advance notice period, and the redemption period. There is large variation in the extent of share restrictions: the combined number of days associated with share restrictions is 60 days for the bottom quartile and over 300 days for the upper quartile. Panel B and $\mathrm{C}$ of Table 2 describe differences in characteristics and stockholdings of hedge funds with share restrictions above and below the median. Differences in most fund characteristics (such as fund TNA and annual fees) tend to be small.

\section{Organizational Structures and Trading in Fire Sale Stocks}

\subsection{Risk and Return of Fire Sale Stocks}

Our objective is to test whether funds with closed- or less open-end structures take more aggressive positions against mispricing. To do so, we identify mispriced stocks following Coval and Stafford (2007), who show that distressed funds experiencing large outflows create negative price pressure on the stocks they hold. As Coval and Stafford (2007), we identify stocks subject to sale pressure due to extreme outflows using the following measure:

$$
\operatorname{Pressure}_{s, t}=\frac{\sum_{i} \max \left(0, \Delta \text { Hold }_{i, s, t}\right) \mid \text { flow }_{i, t}>P 90-\sum_{i} \max \left(0,-\Delta \operatorname{Hold}_{i, s, t}\right) \mid \text { flow }_{i, t}<P 10}{A v g \operatorname{Volume}_{s, t-12: t-6}} .
$$

The pressure experienced by stock $s$ in quarter $t$ is the difference between flow-induced purchases and flow-induced sales during the quarter, divided by the stock's average trading volume during prior quarters. ${ }^{5}$ Flow-induced sales are

\footnotetext{
${ }^{5}$ Following Coval and Stafford (2007), we require a minimum of ten mutual fund owners to compute the Pressure variable.
} 
reductions in shares by mutual funds experiencing severe outflows - that is, quarterly flows below the $10^{\text {th }}$ percentile. Analogously, flow-induced purchases are increases in shares by mutual funds experiencing inflows above the 90th percentile.

As noted in Section 1.1, hereafter, we exclude open-end funds that are considered in the definition of the variable Pressure. Therefore, any differences between closed- and open-end funds cannot be driven by open-end funds with extreme outflows.

Each quarter, stocks with Pressure below the $10^{\text {th }}$ percentile are considered to experience fire sales. Our final sample includes 12,024 fire sales during the period 2004-2014. The minimum and maximum number of fire sales across quarters are, respectively, 291 and 423, and the standard deviation is 37.89 . By construction, fire sales are not clustered over time.

Consistent with Coval and Stafford (2007), as shown in Figure A.1 in the Internet Appendix, also in our sample, stocks subject to fire sales experience large price drops, which typically revert over a horizon of about 24 months. The fire sale quarter (that is, the quarter when a stock's Pressure is in the bottom decile) is the quarter in which fire sale stocks' valuations bottom out. The subsequent reversals distinguish forced trading from other potentially information-motivated trading (Coval and Stafford 2007; Khan, Kogan and Serafeim 2012) because any discretionary selling pressure (caused by sales of mutual funds without extreme outflows) is associated with permanent price declines (thus, not followed by reversals).

Due to the large price reversals, investors who trade against distressed mutual funds can earn substantial returns for providing liquidity. In our sample, the annualized Sharpe ratio from investing in fire sale stocks over a period of 24 months 
is $1.95 .{ }^{6}$ However, the Sharpe ratios from investing in a portfolio of fire sale stocks are considerably lower at short horizons (the Sharpe ratio is 0.05 for holding periods of three months, and 0.76 for holding periods of nine months).

As is evident from Table IA.2 of the Internet Appendix, these features of the risk and return differentiate fire sale stocks from the stocks that our sample open-end funds (i.e., non-distressed open-end funds) purchase. For each open-end fund manager-quarter observation, we identify the fire sale stocks that our sample openend funds sold and the non-fire sale stocks the open-end funds purchased, and compute the monthly abnormal return of these stocks in the subsequent 12 months after the fire-sales event quarter. Table IA.2 shows the risk and return characteristics of these stocks. ${ }^{7}$ Consistently with the findings of Chen, Jegadeesh, Wermers (2000), the average stock purchased by a non-distressed open-end fund earns positive abnormal returns with high certainty in the months immediately following the purchase. In stark contrast, the fire sales stocks sold are riskier and occasionally even experience negative abnormal returns in the months immediately following the fire sale, which indicates uncertainty in the timing of convergence to fundamental value. Despite short-term volatility, fire-sales stocks substantially outperform the stocks purchased by open-end funds at longer horizons.

In summary, differences in performance between stocks that open-end funds purchase and fire sale stocks are consistent with our conjecture that open-end funds neglect fire sales stocks because they focus on safer strategies that yield returns on shorter horizons, but have lower long-term performance.

\footnotetext{
${ }^{6}$ Following Coval and Stafford (2007), we calculate abnormal returns as the equal-weighted returns from buying the portfolio of fire sale stocks and selling all stocks held by mutual funds. Portfolios are rebalanced quarterly to drop all stocks that reach the end of their event period and add all stocks that have recently been involved in a fire sale. We consider the Sharpe ratios of this strategy implemented for different holding periods.

${ }^{7}$ We thank the referee for suggesting this analysis.
} 


\subsection{Descriptive Evidence on Funds' Trading and Performance}

The considerable uncertainty on the timing of fire sale return reversals may discourage asset managers with more open-end structures from purchasing fire sale stocks. We expect these asset managers to aim at less volatile returns even though this may mean to settle for lower overall performance.

To provide evidence that this is the case, we first calculate portfolio returns for closed-end funds from NAV appreciation net of annual fees. Then, using returns net of annual fees for both closed- and open-end funds, we estimate funds' performance as the alpha of the Cahart four-factor model, including the three Fama-French factors and the momentum factor, over a 24-month rolling window. In Table 1, differences in performance between closed- and open-end funds support the conjecture that funds with more open-end structures seek to avoid volatile returns and are able to achieve lower alpha. Consistently with previous literature (e.g., Huang, Wei and, Yan 2007) open-end funds' (monthly, not annualized) alpha is on average small and negative ($0.06 \%$ ), while closed-end funds' alpha is $0.23 \%$, similar to the one reported by Chay and Trzcinka (1999). These differences in alphas between open- and closed-end funds are statistically significant at 5\% level with standard errors double clustered at the fund and time level. Furthermore, the standard deviation of the performance of closed-end funds is almost three times that of open-end funds (1.23\% versus $0.44 \%)$.

We also compare the returns of closed-end funds with those of their matching open-end funds. We match each closed-end fund with an open-end fund within 70$130 \%$ of the closed-end fund's size and that minimizes the sum of the absolute percentage differences in TNA, number of stocks, and exposure to the Fama-French factors and the momentum factor. The matching is performed with replacement. This exercise confirms our earlier findings. Closed-end funds have higher alphas than their 
matching open-end funds $(0.24 \%$ versus $-0.04 \%)$ and their alphas are more volatile $(1.20 \%$ versus $0.51 \%)$. While these performance differences are not necessarily driven exclusively by trading against mispricing, in Table IA.3 of the Internet Appendix, we show that closed-end funds that purchase more fire sale stocks perform better, which is consistent with our hypothesis.

Similarly, we measure hedge funds' performance as the alpha of Fung and Hsieh (2004) eight-factors model, estimated for each fund over a 24-month rolling window. Consistently with the findings of Hombert and Thesmar (2014), Table 2 shows that hedge funds with high share restrictions have higher, but also more volatile performance than hedge funds with low share restrictions.

We also compare the returns of hedge funds with share restrictions above and below the median in a matching sample, in which we match each hedge fund with share restrictions above the median with a hedge fund with share restrictions below the median, which is within $70-130 \%$ of the hedge fund's size and that minimizes the sum of the absolute percentage differences in TNA, number of stocks, and exposure to the Fung-Hsieh factors. The matching is performed with replacement. Results are consistent with previous findings. Hedge funds with share restrictions above the median have an average alpha of $0.42 \%$ and standard deviation of $1.99 \%$. In contrast, hedge funds with share restrictions below the median have an average alpha of $0.33 \%$ and a standard deviation of $1.67 \%$.

Differences in performance appear to be associated with asset managers' different propensities to purchase fire sale stocks. Table 3 describes how funds adjust their stockholdings. At the end of each quarter, we classify a fund's trading activities in a given stock as purchases, sales or unchanged if the fund has increased, decreased or left its holdings of a given stock unchanged during the quarter. We calculate the 
proportion of each of these activities for each fund and quarter and report the sample averages for the funds' entire portfolios, as well as for the subsample of fire sales stocks.

In Panel A, we contrast open- and closed-end funds. While closed- and openend funds' trading activities appear similar when we consider their entire portfolio, stark differences between the two groups of asset managers emerge when we focus on fire sale stocks. During the quarter following the fire sale, $65 \%$ of closed-end funds' trading activities in fire sale stocks are purchases, while only $17 \%$ of open-end funds' trading activities are purchases; $58 \%$ of open-end funds trading activities in fire sale stocks are sales. ${ }^{8}$

\section{[Insert Table 3 here]}

Panel B shows that similar differences emerge for hedge funds with high and low share restrictions. While hedge funds with high share restrictions have a slightly lower propensity to sell and purchase stocks in general, they are more likely to purchase fire sale stocks than hedge funds with low share restrictions $(57 \%$ versus $39 \%$, respectively) in the quarter of the fire sale. ${ }^{9}$

\subsection{Closed-end and Open-end Funds' Trading in Fire Sale Stocks}

\subsubsection{Baseline Results}

To evaluate the significance of the differences in trading behavior between closed- and open-end funds in a systematic way, we estimate the following model for all fire sale stocks:

$$
\Delta \operatorname{shares}(t+k)_{i, s, t}=\alpha+\beta_{1} \text { Closed }_{i}+\beta_{2} X_{s, t}+\beta_{3} X_{i, t}+\beta_{4} X_{t}+\varepsilon_{i, s, t},
$$

\footnotetext{
${ }^{8}$ As we show in Subsection 2.3, this is the quarter in which differences between open- and closed-end funds emerge.

${ }^{9}$ As we show in Subsection 2.4, this is the quarter in which differences between hedge funds with high and low share restrictions emerge.
} 
where $k$ ranges from -2 to +3 . That is, we analyze changes in funds' positions from quarter $t-2$ to quarter $t+3$, where $t$ is the fire sale quarter. ${ }^{10}$ The dependent variable captures the changes in shares held by fund $i$ in stock $s$ between two consecutive quarters, divided by the total number of shares outstanding of stock $s$.

The main variable of interest is the dummy Closed, which is equal to one if fund $i$ is a closed-end fund. ${ }^{11}$ The matrices $X_{s, t}$ and $X_{i, t}$ represent time-varying controls for stock and fund characteristics, respectively. Stock characteristics include market capitalization (Size); idiosyncratic volatility, calculated over the past two years (VOL); a proxy for illiquidity, computed following Amihud (2002) (ILLIQ); book to market value $(B M)$; and cumulative abnormal returns in the past 6 months $(M O M)$. We also control for fund size, measured by the natural logarithm of the fund's TNA $(\log T N A)$ and include time fixed effects to capture market-wide effects. We double cluster standard errors at the fund and time (calendar quarter) levels. ${ }^{12}$

[Insert Table 4 here]

Panel A of Table 4 reports the results showing that there is no statistical difference in the purchases of open- and closed-end funds up to quarter $t$, that is, the quarter when prices bottom out. However, closed-end funds buy significantly more than open-end funds in the quarter following the fire sale, $t+1$. The effect is not only statistically, but also economically significant. To have a more immediate interpretation of the coefficients, we standardize the dependent variable $\Delta \operatorname{shares}(t+$

\footnotetext{
${ }^{10} \mathrm{We}$ analyze funds' trading in fire sales stocks in 6 quarters surrounding the event quarter. Thus, we do not include the fire sales stocks that occurred in the first and last three quarters of the sample period because, for these stocks, we cannot fully characterize the trading around the event quarter. For instance, for a fire sale that occurred in the last quarter of our sample period, we do not observe funds' trading after the event quarter. While this restriction facilitates the comparison of trading behaviour in different quarters, it does not affect our results.

${ }^{11}$ To make the tables easier to read, in some tests, we use the dummy Open (defined as 1-Closed).

${ }^{12}$ Table IA.1 shows that our main result is invariant if we estimate the empirical model using a FamaMacbeth methodology.
} 
$k)_{i, s, t}$ using the standard deviation of all trades of open- and closed-end funds (including trades in non fire sale stocks). Thus, the coefficient of the dummy Closed in column 4 of Table 4 implies that in the quarter following the fire sale, the net purchases of a typical closed-end fund are half of a standard deviation larger than for open-end funds.

We observe no statistical difference in the behavior of closed- and open-end funds in the two following quarters suggesting that differences in trading behavior are driven by the fire sale events and the consequent price drops.

In Panel B, we perform the same test as in Panel A, in a subsample in which we match each closed-end fund with an open-end fund as described in Section 2.2. Differences between closed- and open-end funds continue to emerge only in the quarter following the fire sale. Since we restrict the sample to funds that are similar in terms of size and style, this result indicates that differences in scale between openand closed-end funds or differences in style (as captured by more similar factor exposures) are unlikely to drive our findings. Overall, the evidence in Table 4 suggests that closed-end funds take more aggressive positions against mispricing than open-end funds.

Table 5 explores whether systematic differences in trading between open- and closed-end funds emerge when we consider placebo fire sale stocks. In Panel A, to each fire sale stock (in the fire sale quarter), we match a stock in the same two-digit SIC code industry, within $70-130 \%$ of size, and that minimizes the absolute percentage differences in size and in market to book ratio from the fire sale stock. By construction, these matching stocks have similar characteristics to fire sales stocks, but do not earn significant abnormal returns in subsequent periods. Thus, no 
significant differences in trading between closed- and open-end funds should emerge. This is precisely what we find in Panel A.

In Panel B, we consider differences in trading of stocks that have experienced large discretionary sales. Following Coval and Stafford (2007), we define discretionary sales as large sales by unconstrained funds. More specifically, after excluding the distressed funds from the sample, we define Disc Sales S $_{s, t}=$ $\sum_{i} \Delta$ Hold $_{i, s, t} /$ AvgVolume $_{s, t-12: t-6}$, where $\Delta$ Hold $_{i, s, t}$ is the change in the holdings of fund $i$ in stock $s$ during quarter $t$ and AvgVolume $e_{s, t-12: t-6}$ is stock $s$ ' average trading volume during the prior six quarters. Stocks in the bottom $10^{\text {th }}$ percentile of Disc Sales $_{s, t}$ are defined as discretionary sale stocks. As Coval and Stafford (2007) show, these stocks experience large price drops, but no reversals, because discretionary sales are arguably driven by fundamental information. We repeat our analysis using discretionary sold stocks and find no significant differences between open- and closed-end funds.

\subsubsection{The Role of Stock Characteristics}

To better understand the mechanisms leading to closed- and open-end funds' different propensities to purchase fire sale stocks, we explore the extent to which differences vary with stock characteristics. Since differences in trading emerge in the quarter following the fire sale, we focus the empirical analysis on quarter $t+1$.

If closed-end structures help to overcome limits to arbitrage, we would expect differences between closed- and open-end funds to be more pronounced for stocks with high arbitrage risk (Shleifer and Vishny 1997). Small stocks tend to attract individual investors, whose trades can lead to unpredictable short-term fluctuations in share prices. The increased risk of short-term underperformance makes these stocks 
unattractive for open-end funds. Similarly, stocks with high idiosyncratic volatility are considered to involve high arbitrage risk (e.g., Pontiff 2006). Therefore, we expect open-end funds to be particularly reluctant to trade against mispricing in stocks that are smaller or have higher idiosyncratic volatility. This is precisely what we find in columns 1 and 2 of Table 6 . These results provide strong support for our hypothesis.

[Insert Table 6 here]

Previous literature highlights the propensity of closed-end funds to invest in illiquid assets. Column 3 shows that closed-end funds' trading in fire sale stocks is unrelated to the stocks' liquidity, measured by the price impact ratio of Amihud (2002). Other firm characteristics, such as the book-to-market ratio or the firm's cumulative return over the previous six months, are also unrelated to the trades of closed-end funds in the quarter following a fire sale.

\subsubsection{The Role of the Flow-Performance Sensitivity}

In this section, we provide further evidence on the mechanism behind our baseline results. As predicted by Shleifer and Vishny (1997), we expect open-end funds with high flow-performance sensitivity to be particularly reluctant to purchase fire sale stocks compared to other open-end funds. Column 1 of Table 7 shows that this is indeed the case. Not only do open-end funds on average trade less against mispricing (as captured by the dummy Open), but also open-end funds with higher flow-performance sensitivity are significantly less inclined to do so. This confirms that managers' incentives arising from the sensitivity of flows to performance are important.

[Insert Table 7 here] 
We also examine the role of open-end funds' characteristics. Existing literature documents cross-sectional variation in the degree of open-end funds' flowperformance sensitivity. For instance, asset managers with long tenures have a lower sensitivity of flows to performance because investors are less likely to update their beliefs about senior managers (Choi, Kahraman, and Mukherjee 2016). In addition, open-end funds with a larger fraction of shares held by institutional investors, who have specialized knowledge to evaluate fund managers' strategies, have lower flowperformance sensitivity (James and Karceski 2006; Chen, Goldstein and Jiang 2010).

If the sensitivity of flows to performance constrains long-term risky arbitrage, open-end funds with characteristics associated with a lower sensitivity of flows to performance (more senior managers or more institutional investors) should have stronger incentives to trade against mispricing. ${ }^{13}$ This is precisely what we find. Column 2 shows that open-end fund managers purchase more fire sale stocks as their tenure increases. Column 3 documents that open-end funds' propensity to purchase fire sale stocks increases with institutional ownership. These results support the importance of the flow-performance sensitivity in driving differences between openand closed-end funds.

\subsubsection{Controlling for Financial Slack}

One concern with our results might be that even though we exclude open-end funds that experience extreme outflows, the sample may still include open-end funds that have relatively large outflows and are financially constrained. Table 8 presents a number of tests to assess this possibility as well as to control for the effect of the funds' financial slack. First, we repeat our analysis excluding open-end funds with

\footnotetext{
${ }^{13}$ In these regressions, we interact the dummy Open with open-end fund characteristics, but do not include direct effects, because these fund characteristics are expected to affect the flow-performance sensitivity of open-end funds. The flow-performance sensitivity of closed-end funds is zero .
} 
past flows in the bottom quartile of our sample (of non-distressed funds) and include past flows as a control variable. Columns 1 and 2 show that open-end funds with large outflows do not drive our findings.

\section{[Insert Table 8 here]}

We also consider that financial constraints can arise from funds' pre-existing positions in stocks that become subject to fire sales. Fire sales lead to a large drop in stock prices and cause losses for the funds holding the stocks. If distressed open-end funds have a greater portfolio overlap with other (non-distressed) open-end funds than with closed-end funds, then non-distressed open-end funds are more likely to incur losses because of their pre-existing positions in fire sale stocks. In column 3 , we control for the fund's portfolio weight in fire sale stocks prior to the shock (Prior Exposure). The effect of the organizational structure remains unaffected suggesting that this negative spillover does not drive our findings. Prior Exposure does not appear to affect trading in fire sale stocks, possibly because funds with prior exposure have less financial slack, but are also more likely to have a strategy that justifies purchasing the stock.

We also consider that some closed-end funds use leverage. This may increase their ability to purchase fire sale stocks. As shown in Table 1, and consistent with Cherkes, Sagi, and Stanton (2008) and Dimson (2002), leverage is low for equity closed-end funds (about $6.8 \%$ on average). Therefore, we do not expect closed-end funds' leverage to play an important role. Nevertheless, in column 4, we control for closed-end funds' leverage. We find no evidence that closed-end funds' leverage affects our findings.

In the rest of Table 8, we control for other measures of the funds' financial structure that could vary between open- and closed-end funds. Funds tend to fund 
their purchases with the sales of existing positions. ${ }^{14}$ Funds with a more illiquid portfolio may be unable to mobilize assets to finance purchases of fire sale stocks. To assess this possibility, we control for the average illiquidity of the stocks in each fund's portfolio using the price impact measure of Amihud (2002). We weight each stock using the fund's portfolio weight in the stock. In column 5, controlling for the average stock illiquidity leaves our results invariant. In column 6, we include the proportion of the fund's TNA held as cash. Our results are again unaffected, suggesting that differences in financial slack do not drive our findings. ${ }^{15}$

\subsubsection{Additional Robustness Checks}

Table 9 reports additional robustness checks. In column 1, we control for the similarity between the specialization of distressed and non-distressed open-end funds. Non-distressed open-end funds with similar specialization to the distressed ones may not have financial slack to trade in fire sales stocks. Using the CRSP objective code, we compute the proportion of distressed funds out of all funds that share the same style as fund $f$, and label the variable Distressed Style. Our results are unaffected when we include this control.

Another possible concern is that differences in trading behavior between closed- and open-end funds may be related to differences in managerial ability. In column 2 of Table 9, we control for managerial ability using a manager's alpha,

\footnotetext{
${ }^{14}$ In each quarter, open-end funds and closed-end funds on average sell stocks that are worth $31 \%$ and $25 \%$ of their fund TNA, respectively. A typical open-end fund has a cash stock of $2.9 \%$, and quarterly flows make up about $1.2 \%$ of total net assets. Closed-end funds on average appear to hold negative cash largely driven by the fact that a few of them use leverage.

${ }^{15}$ This conclusion is also supported by evidence showing that differences in trading between open- and closed-end funds emerge during both good and bad market times. In Table IA.4 in the Internet Appendix, we measure market conditions using, in turn, aggregate (open-end) fund flows, the VIX index capturing aggregate market uncertainty, and a dummy variable capturing the recent financial crisis (which we set equal to one from the third quarter of 2008 to the end of 2009 or, alternatively, from the third quarter of 2007 to the end of 2009). The effects we document do not appear to vary with market conditions.
} 
calculated prior to the fire sale quarter. Our findings on the effect of organizational structure remain unaffected although the effect of Closed is somewhat smaller possibly reflecting the fact that comanagers have higher reputation and lower flowperformance sensitivity in their open-end funds than other open-end managers.

To further investigate this concern, we identify 80 unique managers who oversee at least one open- and one closed-end fund. The vast majority of these managers (about 90\%) oversees one open-end fund and one closed-end fund. Column 3 of Table 9 shows that managers who co-manage open- and closed-end funds purchase more fire sale stocks in their closed-end funds than in their open-end funds. This result provides additional evidence that manager-specific characteristics, such as ability, do not drive our findings.

\section{[Insert Table 9 here]}

Another concern is that closed-end fund managers' willingness to trade against mispricing could be affected by the managerial labor market. For instance, an increase in the closed-end funds' discount may lead activist investors to launch campaigns to open the funds (Bradley, Brav, Goldstein, and Jiang 2010). A higher fund discount could also increase the probability of managerial turnover $(\mathrm{Wu}$, Wermers and Zechner 2013). For these reasons, the managers of closed-end funds with high discounts may focus on short-term performance. Although these events are quite rare, we analyze the potential impact of the closed-end fund discount on our results. Unsurprisingly, in column 4, the closed-end fund discount is unrelated to the trading activity of closed-end funds.

Finally, it does not appear that our results are driven by differences in managerial compensation and funds' governance. Managers with different compensation levels may have different risk taking incentives and this may determine 
the differences in trading strategies we observe. As is common in the literature (e.g., Kacperczyk and Schnabl 2013), we proxy for compensation using annual fees. In Table 1, annual fees appear similar for closed- and open-end funds and are therefore unlikely to lead to different trading behavior. Column 5 confirms that annual fees do not have any impact on our findings.

Similarly, in columns 6 and 7, we explore the role of managerial ownership and board quality using data from Morningstar. Morningstar reports open-end fund managers' investments in their funds, and also assigns open-end funds ratings depending on the quality of their boards (Gil-Bazo and Ruiz-Verdu 2009). We create dummy variables to control for whether a fund has high managerial ownership or a board with top quality rating. Our findings appear robust to the inclusion of these controls.

Overall, these tests support that closed-end funds are more inclined to purchase fire sale stocks than open-end funds. The funds' cross-sectional differences and the robustness of the results to a wide set of controls further suggest that the effects are driven by differences in flow-performance sensitivities between closedand open-end funds.

\subsection{Hedge Funds' Trading in Fire Sale Stocks}

To provide an independent test of the degree of open-ending on funds' propensity to purchase fire sale stocks, we turn to hedge funds. Since hedge funds are closer to the ideal of "rational arbitrageurs" than any other class of investors, their trading may be less hampered by open-end structures. Any evidence showing that share restrictions play a role in hedge funds' trading against mispricing would provide strong support for the importance of open-end structures. These tests are also useful 
because hedge funds' flows are likely to be less correlated with the flows of distressed open-end funds.

\section{[Insert Table 10 here]}

Table 10 analyzes the trading of hedge funds in fire sales stocks. Hedge funds exhibit higher propensity to purchase fire sales stocks in the quarter of the fire sale (quarter $t$ ) as their share restrictions increase. The effect is also significant from an economic point of view. If we multiply the difference between the top and bottom quartile of the hedge funds' share restrictions, which is 248 , divide it by 100 , and multiply it by the coefficient of 0.08 , we obtain that high share restrictions hedge funds increase their purchases of fire sale stocks relative to the standard deviation of all trades by 0.2 . Interestingly, if share restrictions are sufficiently high, the effect of share restrictions becomes similar in magnitude to the effect of having a closed-end structure. To see this, consider an increase in share restrictions, for instance, from 0 to 560 days (which is approximately 1.5 years and corresponds to the top decile of share restrictions in the sample). The difference in trading would be $0.08 * 5.6=0.448$, which is similar to the difference in trading between closed- and open-end funds. No differences in trading related to the intensity of share restrictions emerge in other quarters. Table A.5 shows that this conclusion is robust if we match each hedge fund with share restrictions above the median to a hedge fund with share restrictions below the median using the matching algorithm described in Section 2.2. ${ }^{16}$

It appears that hedge funds purchase fire sale stocks more promptly than closed-end funds, which purchase more than open-end funds in the quarter following the fire sale $(t+1)$. While it is possible that hedge funds identify mispricing more readily than other institutional investors, this difference in timing should not be

\footnotetext{
${ }^{16}$ Table A.6 in the Internet Appendix further shows that share restrictions do not affect hedge funds' trading in placebo fire sale stocks, that is, the matching stocks of fire sale stocks and in stocks that experience large discretionary sales.
} 
overemphasized as hedge funds might be buying at the end of the fire sale quarter and closed-end funds at the beginning of the subsequent quarter.

We also analyze the extent to which differences in trading behavior among hedge funds vary with certain stock characteristics. Consistent with our earlier findings on closed-end funds, hedge funds buy fire sale stocks of small firms and of firms with high idiosyncratic volatility to a larger extent as their share restrictions increase (columns 6 and 7 of Table 10). As noted before, these are the stocks that are riskier to arbitrage in the short-term. Therefore, this evidence provides further support for our hypothesis that the degree of open-ending affects asset managers' willingness to trade against mispricing. ${ }^{17}$

\section{Organizational Structures and Exposure to Aggregate Mispricing}

\subsection{Methodology}

We have so far shown differences between funds' trading in fire sale stocks. In this section, we explore whether similar differences exist for more aggregate forms of mispricing driven by investor sentiment. According to behavioral models (e.g., Daniel, Hirshleifer, and Subrahmanyam 2001; Barberis and Shleifer 2003), mispricing arises when noise traders' irrational enthusiasm for stock characteristics shifts. A common prediction of these theories is that noise traders' demand induces positive comovement among stocks with similar characteristics. For instance, the stocks of small companies are systematically undervalued when noise traders' demand is low (Baker and Wurgler 2004; Lemmon and Portniaguina 2006).

Sentiment-driven mispricing suits our conceptual framework because the timing of convergence to fundamental value is uncertain due to the unpredictable

\footnotetext{
${ }^{17}$ Table A.7 in the Internet Appendix shows that all results are robust when we include controls for hedge funds characteristics related to funds' fee structures and minimum investment requirements.
} 
nature of shifts in noise traders' demand. Thus, if closed-end organizational structures indeed favor trading against long-term mispricing, closed-end funds should be relatively more exposed than open-end funds to stocks that are undervalued when noise traders' demand is low.

We test this implication of our hypothesis using a different empirical methodology from the one used for fire sales because fire sales and sentiment-driven mispricing exploit different sources of variation in the data. While there are numerous fire sale stocks in each quarter (Coval and Stafford 2007), sentiment-based mispricing is associated with (time-series) market level changes in investor sentiment. Since changes in investor sentiment are infrequent, it is important to use a long time-series to have sufficient variation in the data.

Therefore, instead of using holdings data, we regress fund returns on the returns of mispriced stocks' portfolios and infer the funds' holdings from the portfolio loadings. This methodology requires only fund returns, which are available both for closed- and open-end funds starting from 1990, and has been used in several studies, including Sharpe (1992), Brown, Goetzmann, and Park (2000), and Brunnermeier and Nagel (2004).

As shown by Brunnermeier and Nagel (2004), each fund's return can be written as the weighted average of the returns on a few asset classes plus idiosyncratic return. Given the focus of our analysis, we consider a portfolio of stocks prone to mispricing and the market return. The return of fund $i$ during month $t\left(R_{i, t}\right)$ can thus be written as:

$$
R_{i, t}=(b-g) R_{m, t}+g R_{s, t}+\epsilon_{i, t}
$$


where $R_{s, t}$ is the monthly return of a portfolio of stocks prone to mispricing $(s)$ and $R_{m, t}$ is the market monthly return. Here $b-g$ is the weight of the fund on the market portfolio; $g$ is the exposure to the portfolio of mispricing-prone stocks. ${ }^{18}$ For a longonly fund tracking the market portfolio (without using any leverage), we would have $b=1$ and $g=0$. A larger $g / b$ implies that the fund's holdings are more tilted towards mispricing-prone stocks.

We expect closed-end funds to be more exposed than open-end funds to stocks with characteristics associated with undervaluation in periods of low noise traders' demand. To capture this, we estimate the following equation in which we allow exposures to mispricing-prone portfolios to differ between open- and closed-end funds and in periods of low noise traders' demand compared to other periods:

$$
\begin{aligned}
& R_{i, t}=\left(b-g_{\text {open }}\right) \times R_{m, t}+\left(b-g_{\text {Closed }}\right) \times \text { Closed }_{i} \times R_{m, t}+ \\
& g_{\text {open }} \times R_{s, t}+g_{\text {Closed }} \times \text { Closed }_{i} \times R_{s, t}+g_{\text {open }}^{\prime} \times \text { Neg Sent }_{t} \times R_{s, t} \\
& \quad++g_{\text {closed }}^{\prime} \times \text { Closed }_{i} \times \text { Neg Sent }_{t} \times R_{s, t}+\Gamma \mathbf{X}_{i, t}+\varepsilon_{i, t} .
\end{aligned}
$$

Neg Sent $t_{t}$ is a dummy that takes value equal to one when noise traders' demand is low as captured by different market sentiment indexes, which we introduce below; Closed $_{i}$ is a dummy identifying closed-end funds; and $\mathbf{X}$ is a matrix of controls that includes the lower-order interaction terms, including the dummy Closed, Neg Sent, Closed $x R_{s}$ and Closed $x$ Neg Sent. The coefficients $b-g_{\text {open }}$ and $b-g_{\text {Closed }}$ capture open- and closed-end funds' exposures to the market portfolio, respectively, while $g_{\text {open }}$ and $g_{\text {Closed }}$ are open- and closed-end funds' exposures to the portfolio of mispricing prone stocks. We allow the funds' exposure to mispricing

\footnotetext{
${ }^{18}$ More specifically, the interpretation is that funds first allocate a fraction $b$ of the total portfolio to the market portfolio, and then reallocate a fraction $g$ of the total portfolio from the initial market investment to stocks to which the funds desire to increase exposure (see Brunnermeier and Nagel 2004 for further discussion on this methodology).
} 
prone stocks to differ in period of negative sentiment as captured by the coefficients, $g^{\prime}{ }_{\text {open }}$ and $g_{\text {closed }}^{\prime}$ In the empirical specification, we also allow the exposures of closed- and open-end funds to the market portfolio and to market sentiment to vary. We expect that $g_{\text {closed }}>0$ if closed-end funds are more inclined to purchase mispricing-prone stocks during periods of low noise traders' demand than open-end funds.

\subsection{Closed-end and Open-end Funds' Exposure to Aggregate Mispricing}

To operationalize the above framework, we identify stock characteristics associated with undervaluation when noise traders' demand is low. We follow Baker and Wurgler (2006) and Lemmon and Portniaguina (2006). ${ }^{19}$ Baker and Wurgler (2006) find that when noise traders' demand (captured by their beginning-of-period measure of market sentiment) is low, young, highly volatile, small, unprofitable, high R\&D, low and high book to market, high external finance, low sale, and non-dividend paying stocks earn particularly high abnormal returns in subsequent periods and can therefore be considered undervalued.

[Insert Table 11 here]

Table 11 relates funds' monthly returns to the monthly returns of portfolios of stocks that are underpriced during periods of negative sentiment (defined using the indicator of sentiment orthogonalized to macro-economic conditions of Baker and Wurgler (2006)).$^{20}$ It is evident that during periods of negative sentiment closed-end

\footnotetext{
${ }^{19} \mathrm{We}$ do not consider other anomalies, for instance, the ones studied by Stambaugh, Yu and Yuan (2012), because profits from these anomalies typically arise on the short leg of the strategy. Open- and closed-end mutual funds are restricted from shorting. Also, not all anomalies involve long-term mispricing.

${ }^{20}$ Baker and Wurgler (2006) define sentiment as the first principal component of six different proxies orthogonalized to several macro variables. The sentiment proxies include trading volume as measured by NYSE turnover, the dividend premium, the average closed-end fund discount, the number and first-
} 
funds are more exposed to portfolios of mispricing-prone stocks. For instance, in periods of low sentiment, closed-end funds appear to overweigh both stocks in the bottom and the top decile of book-to-market, which Baker and Wurgler (2006) identify as similarly undervalued, in comparison to stocks with less extreme book-to market values. Also, the propensity to overweigh mispricing-prone stocks emerges only in periods of negative sentiment for all portfolios but the bottom decile of size and the top decile of book to market. Closed-end funds overweigh small stocks and stocks in the top decile of book to market in comparison to open-end funds also in periods of positive sentiment, albeit to a lower extent than in periods of negative sentiment. The differences are not only statistically but also economically significant. For instance, in column 1 the rate at which closed-end funds overweigh small stocks increases from $7 \%$ to $16 \%$ in periods of negative sentiment. ${ }^{21}$

[Insert Table 12 here]

These results remain unaffected when we perform a number of robustness checks in Table 12. For expositional purposes, Table 12 presents the results of these robustness checks only for small stocks. First, we show that the results in Table 11 are not a by-product of other differences in fund exposures. In column 1, we allow closed- and open-end funds' monthly returns to differ in their exposure to liquidity risk. Our results, if anything, become stronger once we control for different exposure to the Pastor and Stambaugh's (2003) liquidity factor. In column 2, we allow for differences in exposure to the momentum factor. Consistent with Table 1, open-end funds are more heavily invested in momentum stocks but our results are robust. In

day returns on IPOs, and the equity share in new issues. This index is widely used in the literature (e.g., Stambaugh, Yu and Yuan, 2012) and captures historical accounts of bubbles and crashes.

${ }^{21}$ The effects are computed from the coefficients statistically different from zero in Table 11 as (Portfolio + Portfolio $x \quad$ Closed)/(Market+Market $x \quad$ Closed) for normal times and as (Portfolio+Portfolio $x$ Closed + Portfolio $x$ Neg Sent + Portfolio $x$ Neg Sent $x$ Closed)/(Market+Market $x$ Closed) for periods of negative sentiment. 
column 2, we also allow the exposure to the market portfolio to vary in periods of high and low sentiment, but we find no statistically significant differences. Overall, it seems unlikely that open- and closed-end funds' exposure to different factors can explain our findings. ${ }^{22}$

Our results also do not depend on the specific proxy for market sentiment we use. Column 4 shows that closed-end funds appear more exposed to undervalued small stocks also when we capture low noise traders' demand using a measure of sentiment based on consumer surveys of the Michigan Survey Research Center, whose definition does not depend on the closed-end fund discount.

Hirshleifer and Jiang (2010) argue that external financing activities can also be used to identify systematic mispricing arising from noise traders' demand. The patterns in firms' long-run returns suggest that firms issue equity (or risky debt) when they are overvalued, and buy back equity (or retire risky debt) when they are undervalued. Stocks' sensitivities to common movements in this source of mispricing predict the cross-section of asset returns. Hirshleifer and Jiang's (2010) factor allows us to perform a test of our hypothesis without relying on any proxies for market sentiment. Column 5 shows that our earlier conclusions continue to be fully supported: Closed-end funds are significantly more exposed than open-end funds to a portfolio long in stocks that comove with firms that repurchase (and are thus revealed

\footnotetext{
${ }^{22}$ There are a few other observations that emerge from these analyses. First, closed-end funds seem to have a smaller $b-g$, suggesting that they are more active managers deviating from the market portfolio to a larger extent or that they have a preference for low-beta stocks. In addition, across various specifications, we find that the dummy Closed is negative. This finding should be interpreted with caution; specifically, this estimate does not imply that closed-end funds have weaker performance than open-end funds. These regressions control for exposure to mispricing-prone stocks. Exposure to mispricing-prone stocks in periods of negative sentiment captures the component of the fund portfolio that will generate positive abnormal performance. Thus, the dummy Closed does not capture the differences in the overall fund returns but only the remaining part of the fund portfolio. In Section 2.2, we analyze fund alphas calculated using the entire fund portfolio and show that closed-end funds have higher performance. Finally, we observe that, except for a few cases, the term Portfolio $x$ Closed is insignificant. This may indicate that, perhaps due to constraints in shorting, the differences in trading against undervalued stocks is stronger than the differences in trading against overvalued stocks.
} 
to be undervalued) and short in stocks that comove with firms that issue equity or risky debt (and are thus revealed to be overvalued).

Finally, while we estimate funds' time-varying exposures to mispricing-prone using return regressions (so as to be able to exploit a longer sample period), column 6 confirms our findings in the (shorter) holdings sample. We regress the percentage change in a fund's portfolio weight in small stocks on the Closed dummy interacted with a dummy variable capturing periods of negative sentiment, and the direct effect of each of these variables. The interaction term is positive and significant indicating that closed-end funds increase their exposure to small stocks by nearly $4 \%$ in periods of negative sentiment.

\subsection{Hedge Funds' Exposure to Aggregate Mispricing}

We also test whether hedge funds with high share restrictions hold portfolios that are more exposed to mispriced stocks during periods of negative sentiment.

\section{[Insert Table 13 here]}

The estimates in Table 13 are in line with our earlier findings. While on average hedge funds decrease their exposure to mispricing-prone stocks in periods of negative sentiment, hedge funds with higher share restrictions do less so. Hedge funds with particularly high share restrictions even increase their exposure to mispricing prone stocks. For instance, in column 1, hedge funds with share restrictions above 560 days (approximately 1.5 years) increase their exposure to small stocks in periods of negative sentiment, when they are more likely to be undervalued.

These results remain unaffected when we perform a number of robustness checks, mirroring the ones we perform for closed-end funds, in Table IA.8 of the Internet Appendix. 


\section{Conclusions}

This paper provides evidence that open-end structures weaken managerial incentives to trade against mispricing, as conjectured by Shleifer and Vishny (1997). We show that closed-end funds and, to some extent, hedge funds with high share restrictions are more likely to trade against mispricing.

Our paper contributes to the debate on the organization of the asset management industry. Open- and closed-end fund structures involve costs and benefits. Fama and Jensen (1983) argue that open-ending might be an optimal response to agency problems. If a fund is set up on a closed-end basis, dispersed investors have no recourse in the face of managerial misbehavior and may see their entire investment slowly eaten away. However, Stein (2005) challenges this view and shows that because of competition, too many asset managers may choose an open-end structure and too little capital may be available for long-term arbitrage.

This paper provides empirical evidence on the benefit of closed-end fund structures (and share restrictions). While our analysis is silent about the potential agency costs of closed-end fund structures, Wu, Wermers and Zechner (2013) suggest that managerial career concerns may provide a disciplining mechanism alternative to fund flows and thus help resolving potential agency problems in closed-end funds. Further assessing the costs and benefits of closed- and open-end organizational structures is an exciting area for future research. 


\section{References}

Agarwal, V., and N. Y. Naik. 2004. Risks and portfolio decisions involving hedge funds. Review of Financial Studies 17: 63-98.

Agarwal, V., N. D. Daniel, and N. Y. Naik. 2009. Role of managerial incentives and discretion in hedge fund performance. Journal of Finance 64: 2221-2256.

Agarwal, V., V. Fos, and W. Jiang. 2013. Inferring Reporting-Related Biases in Hedge Fund Databases from Hedge Fund Equity Holdings. Management Science 59: 1271-1289.

Agarwal, V., W. Jiang, Y. Tang, and B. Yang. 2013. Uncovering hedge fund skill from the portfolio holdings they hide. Journal of Finance 68: 739-783.

Almazan, A., K. C. Brown, M. Carlson, and D. A. Chapman. 2004. Why constrain your mutual fund manager? Journal of Financial Economics 73: 289-321.

Akbas, F., W. J. Armstrong, S. Sorescu, and A. Subrahmanyam. 2014. Smart Money, Dumb Money, and Equity Return Anomalies. Journal of Financial Economics, forthcoming.

Amihud, Y. 2002. Illiquidity and Stock Returns: Cross-section and Time-series Effects. Journal of Financial Markets 5:31-56.

Aragon, G. O. 2007. Share restrictions and asset pricing: Evidence from the hedge fund industry. Journal of Financial Economics 83:33-58.

Baker, M., and J. Wurgler. 2006. Investor Sentiment and the Cross-Section of Stock Returns. Journal of Finance 61:1645-1680.

Baker, M., and J. Wurgler. 2007. Investor sentiment in the stock market. Journal of Economic Perspectives 21:129-151.

Barberis, N., and A Shleifer. 2003. Style Investing. Journal of Financial Economics 68: 161-99.

Berk, J. B., and R. Stanton. 2007. Managerial Ability, Compensation, and the Closed $\square$ End Fund Discount. Journal of Finance 62: 529-556.

Bloomfield, R., M. O’Hara, and G. Saar. 2009. How Noise Trading Affects Markets: An Experimental Analysis. Review of Financial Studies 22: 2275-2302.

Bradley, M., A. Brav, I. Goldstein, and W. Jiang. 2010. Activist arbitrage: a study of open-ending attempts of closed-end funds. Journal of Financial Economics 95: 1-19.

Brunnermeier, M., and S. Nagel. 2004. Hedge funds and the technology bubble. Journal of Finance 59, 2013-2040. 
Brown, Steven J., and W. N. Goetzmann. 2003. Hedge funds with style. Journal of Portfolio Management 29:101-112.

Cao, C., Y. Chen, W. N. Goetzmann, and B. Liang. 2012. The Role of Hedge Funds in the Security Price Formation Process. Working Paper, Yale University.

Cella, C., A. Ellul, and M. Giannetti. 2013. Investors' Horizons and the Amplification of Market Shocks. Review of Financial Studies 26: 1607-1648.

Chay, J. B., and C.A. Trzcinka. 1999. Managerial performance and the cross-sectional pricing of closed-end funds. Journal of Financial Economics 52: 379-408.

Chen, H., N. Jegadeesh, N., and R. Wermers. 2000. The value of active mutual fund management: An examination of the stockholdings and trades of fund managers. Journal of Financial and Quantitative Analysis 35: 343-368.

Chen, Q., I. Goldstein, and W. Jiang. 2010. Payoff complementarities and financial fragility: Evidence from mutual fund outflows. Journal of Financial Economics 97: 239-262.

Cherkes, M., J. Sagi, J., and R. Stanton. 2008. A Liquidity-Based Theory of ClosedEnd Funds. Review of Financial Studies 22: 257-297.

Choi, D., B. Kahraman, A. Mukherjee. 2016. Learning About Mutual Fund Managers. Journal of Finance 71, 2809-2859.

Coval, J., and E. Stafford. 2007. Asset fire sales (and purchases) in equity markets. Journal of Financial Economics 86: 479-12.

Daniel, K., D. Hirshleifer, and A. Subrahmanyam. 2001. Overconfidence, Arbitrage, and Equilibrium Asset Pricing. Journal of Finance 56: 921-965.

Dimson, E., and C. M. Kozerski. 2002. Closed $\square$ End Funds: A Survey. Financial Markets, Institutions \& Instruments 8: 1-41.

Edelen, R M, O Ince, and G B Kadlec. 2016. Institutional Investors and Stock Return Anomalies. Journal of Financial Economics 119: 472-488.

Fama, E. F., and M. C. Jensen. 1983. Agency problems and residual claims. Journal of Law and Economics, 26: 327-349.

Fung, W., and D.A. Hsieh. 2004. Hedge fund benchmarks: A risk-based approach. Financial Analysts Journal 60: 60-80.

Gil-Bazo, J., and P. Ruiz-Vendu. 2009. The Relation between Price and Performance in the Mutual Fund Industry. Journal of Finance 64: 2153-2183.

Goetzmann, W. N., J. E. Ingersoll, and S. A. Ross. 2003. High-water marks and hedge fund management contracts. Journal of Finance 43:1685-1717. 
Greenwood, R., and S. Nagel. 2009. Inexperienced investors and bubbles. Journal of Financial Economics 93: 239-258.

Hirshleifer, D., and D. Jiang. 2010. A Financing-Based Misvaluation Factor and the Cross-Section of Expected Returns. Review of Financial Studies 23: 3401-3436.

Hombert, J., and D. Thesmar. 2014. Overcoming limits of arbitrage: Theory and evidence. Journal of Financial Economics 111: 26-44.

Huang, J., K. D. Wei, and H. Yan. 2007. Participation costs and the sensitivity of fund flows to past performance. Journal of Finance 62:1273-1311.

James, C., and J. Karceski. 2006. Investor monitoring and differences in mutual fund performance. Journal of Banking and Finance 30:2787-2808.

Kacperczyk, M., and P. Schnabl. 2013. How Safe Are Money Market Funds? Quarterly Journal of Economics 128:1073-1122.

Khan, M., L. Kogan, and G. Serafeim. 2012. Mutual Fund Trading Pressure: FirmLevel Stock Price Impact and Timing of SEOs. Journal of Finance 67:1371-1395.

Kokkonen, J., and M. Suominen. 2015. Hedge Funds and Stock Market Efficiency. Management Science 61:2890-2904.

Khorana, A., S. Wahal, and M. Zenner, M. 2002. Agency Conflicts in Closed-End Funds: The Case of Rights Offerings. Journal of Financial and Quantitative Analysis, 37:177-200.

Lemmon, M., and E. Portniaguina. 2006. Consumer Confidence and Asset Prices: Some Empirical Evidence. Review of Financial Studies 19:1499-1529.

Mitchell, M., L. H. Pedersen, and T. Pulvino. 2007. Slow Moving Capital. American Economic Review 97:215-220.

Pastor, L., and R. F. Stambaugh. 2003. Liquidity risk and expected stock returns. Journal of Political Economy 111:642-85.

Pontiff, J. 2006. Costly Arbitrage and the Myth of Idiosyncratic Risk. Journal of Accounting and Economics 42: 35-52.

Ross, S. A. 2002. A neoclassical look at behavioral finance; closed-end funds, Princeton Lectures in Finance III.

Sadka, R. 2010. Liquidity risk and the cross-section of hedge-fund returns. Journal of Financial Economics 98, 54-71.

Sharpe, W, F. 1992. Asset allocation: Management style and performance measurement, Journal of Portfolio Management, Winter, 7-19. 
Shleifer, A., and R.W. Vishny. 1997. The Limits of Arbitrage. Journal of Finance 52: $35-55$.

Stambaugh, R. F., J. Yu, and Y. Yuan. 2012. The short of it: Investor sentiment and anomalies. Journal of Financial Economics 104: 288-302.

Stein, J. C. 2005. Why are most funds open-end? Competition and the limits to arbitrage. Quarterly Journal of Economics 120:247-72.

Tetlock, P. C. 2008. Liquidity and Prediction Market Efficiency. Working Paper, Columbia University.

Wahal, S., and A. Y. Wang. 2011. Competition among mutual funds. Journal of Financial Economics 99:40-59.

Wu, Y., R. Wermers, and J. Zechner. 2013. Managerial Rents vs. Shareholder Value in Delegated Portfolio Management: The Case of Closed-End Funds. Working Paper, University of Maryland. 


\section{Appendix \\ Variable Definitions}

\section{Fund-level Characteristics}

\begin{tabular}{|c|c|}
\hline Closed & A dummy variable that is equal to one for closed-end funds. \\
\hline Open & A dummy variable that is equal to one for open-end funds. \\
\hline Share Restrictions & $\begin{array}{l}\text { Sum of the days of the lock up period, redemption notice period } \\
\text { and payout period, divided by } 100 \text { in the empirical analysis; for } \\
\text { hedge funds without lock up period, redemption notice period } \\
\text { and payout period, this variable is set to zero. }\end{array}$ \\
\hline High Restrictions & $\begin{array}{l}\text { A dummy variable that is equal to one if the hedge fund has } \\
\text { share restrictions above sample median. }\end{array}$ \\
\hline Lock up period & $\begin{array}{l}\text { Minimum time an investor has to wait to withdraw after her } \\
\text { initial investment. }\end{array}$ \\
\hline $\begin{array}{l}\text { Redemption notice } \\
\text { period }\end{array}$ & $\begin{array}{l}\text { Advance notice an investor has to give to the fund before being } \\
\text { able to withdraw. }\end{array}$ \\
\hline Payout period & $\begin{array}{l}\text { Time that the fund takes to return the capital after the notice } \\
\text { period is over. }\end{array}$ \\
\hline Log TNA & Natural logarithm of the fund's TNA as of quarter-end. \\
\hline Flow & $\begin{array}{l}\text { Monthly change in TNA less the total returns over the month, } \\
\text { divided by the previous month TNA; winsorized at } 2.5 \% \text {. }\end{array}$ \\
\hline FPS & $\begin{array}{l}\text { A fund's flow performance sensitivity, estimated regressing the } \\
\text { fund's monthly net flows on its past } 12 \text { month average monthly } \\
\text { returns using a } 24 \text { month rolling window; it is always equal to } \\
\text { zero for closed-end funds; winsorized at } 2.5 \% \text {. }\end{array}$ \\
\hline Alpha & $\begin{array}{l}\text { For open- and closed-end funds, alpha is the four-factor alpha } \\
\text { (in \%); estimated from } 24 \text { months rolling regressions. For } \\
\text { closed-end funds, returns are computed using changes in the } \\
\text { NAV. For hedge funds, alpha is computed using the Fung and } \\
\text { Hsieh (2004) eight-factor model. All fund returns are net of } \\
\text { annual fees. }\end{array}$ \\
\hline Discount & $\begin{array}{l}\text { Average closed-end fund discount, (NAV-share price)/NAV in } \\
\text { the past } 12 \text { months; winsorized at } 1 \% \text {. }\end{array}$ \\
\hline Annual Fees & The fund's annual expense ratio. \\
\hline Distressed Style & $\begin{array}{l}\text { The ratio of the number of distressed funds to the total number } \\
\text { of funds with the investment style of an open-end fund. We } \\
\text { define funds' investment styles using CRSP objective codes, } \\
\text { which are available only for open-end funds. }\end{array}$ \\
\hline Leverage & $\begin{array}{l}\text { Closed-end funds' total debt, divided by total assets. Obtained } \\
\text { from Capital IQ at annual frequency and populated for the entire } \\
\text { year. }\end{array}$ \\
\hline Past Flows & $\begin{array}{l}\text { Average monthly fund flows in the past } 12 \text { months, as a } \\
\text { proportion of TNA at the beginning of the period. }\end{array}$ \\
\hline Tenure & $\begin{array}{l}\text { Natural logarithm of an open-end fund manager's tenure (in } \\
\text { years). }\end{array}$ \\
\hline Cash & Fund's cash holdings, divided by the fund's TNA. \\
\hline Prior Exposure & Total portfolio weight of fire sale stocks in a fund's portfolio 6 \\
\hline
\end{tabular}




\begin{tabular}{l|l}
\hline Institutional & months prior to the fire sale event. \\
\hline High Man Ownership & $\begin{array}{l}\text { Fund assets held by institutional investors, divided by the fund's } \\
\text { TNA; available only for open-end funds. } \\
\text { ownership in the top quartile. Managerial ownership measures } \\
\text { managers' direct investments in their fund and is obtained from } \\
\text { Morningstar in thousands \$; available only for open-end funds. }\end{array}$ \\
\hline High board quality & $\begin{array}{l}\text { A dummy variable that is equal to one for open-end funds with } \\
\text { the top board quality grade. The board quality grade can be A, } \\
\text { B, C or D and is obtained from Morningstar; available only for } \\
\text { open-end funds. }\end{array}$ \\
\hline Fund ILLIQ & $\begin{array}{l}\text { Weighted average of the Amihud (2002) illiquidity measure } \\
\text { (ILLIQ) of the stocks in a fund's portfolio. }\end{array}$ \\
\hline Incentive Fee & Annual incentive fee charged by hedge funds. \\
\hline High-water mark & $\begin{array}{l}\text { A dummy variable that is equal to one if a hedge fund imposes } \\
\text { high-water marks. }\end{array}$ \\
\hline Min Inv & Minimum investment required by a hedge fund (in thousand \$). \\
\hline Leveraged & $\begin{array}{l}\text { A dummy variable that is equal to one if a hedge fund uses } \\
\text { leverage. }\end{array}$ \\
\hline
\end{tabular}

\section{$\underline{\text { Stock-level Characteristics }}$}

\begin{tabular}{l|l}
\hline VOL & $\begin{array}{l}\text { Standard deviation of idiosyncratic monthly returns, calculated } \\
\text { over a 2-year window (in \%). Idiosyncratic monthly returns are } \\
\text { the residuals in a regression of a stock's monthly return on } \\
\text { the three Fama and French (1993) factors }\end{array}$ \\
\hline ILLIQ & $\begin{array}{l}\text { A proxy for illiquidity, computed following Amihud (2002), as } \\
\text { the average ratio of the absolute value of daily returns to the } \\
\text { stock daily volume in a given quarter; winsorized at } 1 \%\end{array}$ \\
\hline Size & Market capitalization at the quarter end (in millions) \\
\hline BM & $\begin{array}{l}\text { Ratio of the latest book value from annual statements to the } \\
\text { latest market value in a given quarter }\end{array}$ \\
\hline$\Delta s h a r e s(t)_{i, s, t}$ & Cumulative monthly returns in the past six months \\
\hline & $\begin{array}{l}\text { The change in number of shares held by fund } i \text { in stock } s \\
\text { between the end of quarter } t \text { and } t-1 \text { as a fraction of stock } i \text { 's } \\
\text { total shares outstanding at the end of quarter } t-1, \text { scaled by its } \\
\text { standard deviation (in \%). It varies across firms, funds, and } \\
\text { quarters. }\end{array}$ \\
\hline
\end{tabular}

\section{Characteristics-Based Portfolios}

\begin{tabular}{l|l}
\hline Small & $\begin{array}{l}\text { A dummy variable that is equal to one if market equity is in the } \\
\text { bottom decile, based on NYSE breakpoints. Market equity is } \\
\text { defined as price times shares outstanding as of June of year } t .\end{array}$ \\
\hline Young & $\begin{array}{l}\text { A dummy variable that is equal to one if the firm's age is in the } \\
\text { bottom decile, based on NYSE breakpoints. Age is the number } \\
\text { of years since the firm's first appearance in CRSP, measured to } \\
\text { the nearest month in June of year } t .\end{array}$ \\
\hline
\end{tabular}




\begin{tabular}{|c|c|}
\hline High Vol & $\begin{array}{l}\text { A dummy variable that is equal to one if a firm volatility is in } \\
\text { the top decile, based on NYSE breakpoints. A firm's volatility } \\
\text { is the standard deviation of monthly returns over the } 12 \text { months } \\
\text { ending in June of year } t \text {. }\end{array}$ \\
\hline Nonprofitable & $\begin{array}{l}\text { A dummy variable that is equal to one if } \mathrm{E}<=0 \text {, where } \mathrm{E} \text { is } \\
\text { income before extraordinary items (Item 18) plus income } \\
\text { statement deferred taxes (Item 50) minus preferred dividends } \\
\text { (Item 19). }\end{array}$ \\
\hline High BM & $\begin{array}{l}\text { A dummy variable that is equal to one if BM is in the top decile, } \\
\text { based on NYSE breakpoints. BM is the book value of equity at } \\
\text { the fiscal year-end of calendar year } t-1 \text {, divided by market } \\
\text { equity. The book value of equity is measured at the fiscal year- } \\
\text { end of calendar year } t-1 \text {. Market equity is defined as price } \\
\text { times shares outstanding as of June of year } t \text {. }\end{array}$ \\
\hline Low BM & $\begin{array}{l}\text { A dummy variable that is equal to one if BM is in the bottom } \\
\text { decile, based on NYSE breakpoints. BM is the book value of } \\
\text { equity at the fiscal year-end of calendar year } t-1 \text {, divided by } \\
\text { market equity. The book value of equity is measured at the } \\
\text { fiscal year-end of calendar year } t-1 \text {. Market equity is defined } \\
\text { as price times shares outstanding as of June of year } t \text {. }\end{array}$ \\
\hline Nonpayer & $\begin{array}{l}\text { A dummy variable that is equal to one if the company does not } \\
\text { pay out dividends (Item 26). }\end{array}$ \\
\hline High R\&D & $\begin{array}{l}\text { A dummy variable that is equal to one if RD is in the top decile, } \\
\text { based on NYSE breakpoints. RD is defined as research and } \\
\text { development expenditures (Item } 46 \text { ) over total assets at the } \\
\text { fiscal year-end of calendar year } t-1 \text {. }\end{array}$ \\
\hline High External Finance & $\begin{array}{l}\text { A dummy variable that is equal to one if External Finance is in } \\
\text { the top decile, based on NYSE breakpoints. External Finance is } \\
\text { defined as the change in assets (Item 6) minus the change in } \\
\text { retained earnings (Item } 36 \text { ), divided by total assets at the fiscal } \\
\text { year-end of calendar year } t-1 \text {. }\end{array}$ \\
\hline Low Sales & $\begin{array}{l}\text { A dummy variable that is equal to one if Sales Growth is in the } \\
\text { bottom decile, based on NYSE breakpoints. Sales Growth is } \\
\text { defined as the change in net sales (Item 12), divided by prior- } \\
\text { year net sales at the fiscal year-end of calendar year } t-1 \text {. }\end{array}$ \\
\hline
\end{tabular}


Table 1

Descriptive Statistics: Open-end versus Closed-end Funds

\begin{tabular}{|c|c|c|c|c|c|c|}
\hline \multirow[b]{2}{*}{ Variable } & \multicolumn{3}{|c|}{ Open-End Funds } & \multicolumn{3}{|c|}{ Closed-End Funds } \\
\hline & Mean & Median & Std Dev & Mean & Median & Std Dev \\
\hline \multicolumn{7}{|c|}{ Panel A: Fund Characteristics } \\
\hline Log TNA & 5.4958 & 5.7064 & 1.4155 & 5.7135 & 5.7048 & 1.1188 \\
\hline Fees & 0.0132 & 0.0124 & 0.0051 & 0.0136 & 0.0125 & 0.0055 \\
\hline Alpha & -0.0633 & -0.0710 & 0.4449 & 0.2327 & 0.1931 & 1.2304 \\
\hline FPS & 0.2264 & 0.1315 & 0.7496 & & & \\
\hline Cash & 0.0285 & 0.0177 & 0.0373 & -0.0621 & 0.0069 & 0.1817 \\
\hline Prior Exposure & 6.5653 & 4.3265 & 8.2565 & 4.0158 & 2.3408 & 5.3073 \\
\hline Flows & 0.0041 & 0.0018 & 0.0293 & & & \\
\hline Tenure & 1.8653 & 1.9459 & 0.8457 & & & \\
\hline Man ownership & 298.86 & 187.50 & 3248.15 & & & \\
\hline High board quality & 0.1159 & 0.0000 & 0.3201 & & & \\
\hline Institutional & 0.2157 & 0.0077 & 0.3608 & & & \\
\hline Distressed Style & 0.0947 & 0.0909 & 0.0346 & & & \\
\hline Discount & & & & 0.0540 & 0.0694 & 0.0891 \\
\hline Leverage & & & & 0.0688 & 0.0000 & 0.1125 \\
\hline \multicolumn{7}{|c|}{ Panel B: Stock Characteristics } \\
\hline MOM & 0.1170 & 0.0896 & 0.3886 & 0.0706 & 0.0595 & 0.3046 \\
\hline Size & 8.3789 & 8.2480 & 1.8015 & 8.9410 & 9.0650 & 1.8791 \\
\hline VOL & 7.8589 & 6.6958 & 4.8241 & 6.8055 & 5.7231 & 4.1542 \\
\hline ILLIQ & 0.0464 & 0.0004 & 1.7075 & 0.1568 & 0.0002 & 3.4882 \\
\hline $\mathrm{BM}$ & 0.7045 & 0.4384 & 4.7456 & 1.0736 & 0.5108 & 5.8475 \\
\hline
\end{tabular}

This table reports the descriptive statistics for the holdings sample of open- and closed-end funds. The sample covers quarterly observations for 436 closed-end funds and 1,196 open-end funds from January 2004 to December 2014. The total number of fund-quarter observations is 6,437 for closed-end funds, and 23,869 for open-end funds. Panel A reports the descriptive statistics on the main fund characteristics. Some fund characteristics (such as Discount, FPS, Flows) are defined only for either open- or closed-end funds. Other fund characteristics (such as Man ownership, Institutional) are available only for open-end funds. Panel B summarizes characteristics of the quarterly holdings of open- and closed-end funds. All variables are defined in the Appendix. 
Table 2

Descriptive Statistics: Hedge Funds

Panel A: Share Restrictions

\begin{tabular}{lrrrrr}
\hline Variable & P25 & Mean & Median & P75 & Std \\
\hline Redemption notice period & 30 & 43.8320 & 37.5 & 60 & 24.0942 \\
Payout period & 15 & 46.5878 & 30.4167 & 67.5 & 42.1577 \\
Lock up period & 0 & 120.5533 & 12.0000 & 194.0000 & 174.6018 \\
Share restrictions & 60 & 197.94 & 120 & 308.50 & 190.96 \\
\hline
\end{tabular}

Panel B: Fund Characteristics

\begin{tabular}{lcccccc}
\hline Share Restrictions & \multicolumn{3}{c}{ Low } & \multicolumn{3}{c}{ High } \\
\hline Variable & Mean & Median & Std & Mean & Median & Std \\
Log TNA & 15.2171 & 16.1312 & 3.6711 & 14.6731 & 14.2555 & 3.5512 \\
Alpha & 0.3012 & 0.2841 & 1.6431 & 0.4132 & 0.3639 & 1.9721 \\
Annual fees & 0.0138 & 0.0125 & 0.0051 & 0.0137 & 0.0150 & 0.0042 \\
Incentive fees & 0.1796 & 0.2000 & 0.0533 & 0.1914 & 0.2000 & 0.0313 \\
High-water marks & 0.7832 & 1.0000 & 0.3386 & 0.8970 & 1.0000 & 0.2550 \\
Leveraged & 0.5802 & 0.6364 & 0.4372 & 0.6352 & 0.8000 & 0.4135 \\
Min Inv & $1,546,350$ & $1,000,000$ & $2,939,394$ & $1,492,286$ & $1,000,000$ & $1,573,602$ \\
\hline
\end{tabular}

Panel C: Stock Characteristics

\begin{tabular}{lcccccc}
\hline Share Restrictions & \multicolumn{3}{c}{ Low } & \multicolumn{3}{c}{ High } \\
\hline Variable & Mean & Median & Std & Mean & Median & Std \\
MOM & 0.1162 & 0.0652 & 0.4999 & 0.1083 & 0.0599 & 0.4968 \\
Size & 7.4915 & 7.4213 & 2.0118 & 7.5418 & 7.4687 & 2.0121 \\
VOL & 9.3212 & 7.9735 & 5.7511 & 9.7237 & 8.2761 & 5.9110 \\
ILLIQ & 0.3008 & 0.0014 & 4.3447 & 0.2905 & 0.0012 & 4.1765 \\
BM & 0.6821 & 0.4026 & 1.3551 & 0.6618 & 0.3988 & 1.2714 \\
\hline
\end{tabular}

This table reports the descriptive statistics for the hedge funds' holdings sample. The sample covers quarterly observations for 355 hedge funds' management companies from January 1994 to December 2014. The total number of management company-quarter observations is 10,308. Panel A provides the statistics on different types of share restrictions (reported in days). In Panels B and C, we divide the sample in two groups according to hedge funds' share restrictions. Low represents the group with share restrictions below the median; High represents the group with share restrictions above the median. For each group of hedge funds, Panel B describes fund characteristics and Panel C describes the characteristics of hedge funds' stockholdings. All variables are defined in the Appendix. 
Table 3

Trading Activities

Panel A. Closed- and Open-End Funds

\begin{tabular}{llcc}
\hline Fund & & Entire Portfolio & Fire Sale \\
\hline Open & Purchase & 0.3212 & 0.1722 \\
& Sell & 0.3408 & 0.5858 \\
& Unchanged & 0.3380 & 0.2420 \\
Closed & & & \\
& Purchase & 0.2779 & 0.6510 \\
& Sell & 0.2776 & 0.1032 \\
& Unchanged & 0.4444 & 0.2458 \\
\hline
\end{tabular}

Panel B. Hedge Funds

\begin{tabular}{llcc}
\hline Share Restrictions & & Entire Portfolio & Fire Sales \\
\hline Low & Purchase & 0.3229 & 0.3950 \\
& Sell & 0.3913 & 0.3737 \\
& Unchanged & 0.2858 & 0.2313 \\
High & & & \\
& Purchase & 0.2905 & 0.5774 \\
& Sell & 0.3571 & 0.2102 \\
& Unchanged & 0.3524 & 0.2123
\end{tabular}

This table describes funds' trading activities. For each stock-fund-quarter observation, we determine whether the fund made a purchase, a sale, or left the position unchanged during the quarter. We calculate the proportion of these trading activities (Purchase, Sale, Unchanged) and report the sample averages for the funds' entire portfolios, as well as for fire sale stocks. Panel A reports the descriptive statistics for closed- and open-end funds. Panel B reports analogous statistics for hedge funds with high share restrictions (above the median) and hedge funds with low share restrictions (below the median). 
Table 4

Closed- and Open-end Funds' Trades in Fire Sale Stocks

Panel A. Whole sample

\begin{tabular}{lcccccc}
\hline & $(1)$ & $(2)$ & $(3)$ & $(4)$ & $(5)$ & $(6)$ \\
& $\Delta$ Shares $(\mathrm{t}-2)$ & $\Delta$ Shares $(\mathrm{t}-1)$ & $\Delta$ Shares $(\mathrm{t})$ & $\Delta$ Shares $(\mathrm{t}+1)$ & $\Delta$ Shares $(\mathrm{t}+2)$ & $\Delta$ Shares $(\mathrm{t}+3)$ \\
\hline \multirow{2}{*}{ Closed } & & & & & & \\
& 0.0841 & -0.0979 & 0.1447 & $0.5021^{* * *}$ & 0.1281 & 0.1417 \\
ILLIQ & $(0.170)$ & $(0.071)$ & $(0.156)$ & $(0.181)$ & $(0.165)$ & $(0.116)$ \\
& -0.0224 & -0.0044 & 0.0157 & 0.0566 & -0.0026 & $-0.0150^{*}$ \\
MOM & $(0.017)$ & $(0.005)$ & $(0.028)$ & $(0.054)$ & $(0.051)$ & $(0.008)$ \\
& $0.9594^{* *}$ & 0.2594 & 0.2895 & 0.2405 & $0.5213^{* *}$ & $0.3668^{*}$ \\
Size & $(0.375)$ & $(0.158)$ & $(0.259)$ & $(0.184)$ & $(0.228)$ & $(0.222)$ \\
& $-0.1730^{* * *}$ & $-0.1027^{* * *}$ & $-0.1218^{* * *}$ & $-0.1495^{* * *}$ & $-0.1167^{* * *}$ & $-0.1101^{* * *}$ \\
VOL & $(0.039)$ & $(0.020)$ & $(0.036)$ & $(0.028)$ & $(0.038)$ & $(0.034)$ \\
& $0.0546^{* * *}$ & 0.0138 & -0.0067 & 0.0022 & $0.0349^{* *}$ & $0.0499^{* *}$ \\
BM & $(0.019)$ & $(0.009)$ & $(0.014)$ & $(0.014)$ & $(0.016)$ & $(0.023)$ \\
& 0.1298 & 0.0210 & -0.1389 & 0.0612 & 0.2259 & 0.0938 \\
Log TNA & $(0.149)$ & $(0.049)$ & $(0.103)$ & $(0.066)$ & $(0.166)$ & $(0.119)$ \\
& $0.2278^{* * *}$ & $0.1111^{* * *}$ & $0.0720^{*}$ & $0.1069^{* * *}$ & $0.1003^{* * *}$ & $0.1280^{* * *}$ \\
& $(0.043)$ & $(0.019)$ & $(0.037)$ & $(0.025)$ & $(0.035)$ & $(0.035)$ \\
N & & & & & & \\
R-square & 156,586 & 157,215 & 156,954 & 152,543 & 151,742 & 149,692 \\
& 0.003 & 0.003 & 0.002 & 0.002 & 0.002 & 0.001 \\
\hline
\end{tabular}


Panel B. Matched Sample

\begin{tabular}{|c|c|c|c|c|c|c|}
\hline & $\begin{array}{c}(1) \\
\Delta \text { Shares (t-2) }\end{array}$ & $\begin{array}{c}(2) \\
\Delta \text { Shares (t-1) }\end{array}$ & $\begin{array}{c}(3) \\
\Delta \text { Shares (t) }\end{array}$ & $\begin{array}{c}(4) \\
\Delta \text { Shares }(t+1)\end{array}$ & $\begin{array}{c}(5) \\
\Delta \text { Shares }(t+2)\end{array}$ & $\begin{array}{c}(6) \\
\Delta \text { Shares }(\mathrm{t}+3)\end{array}$ \\
\hline Closed & $\begin{array}{l}0.0592 \\
(0.229)\end{array}$ & -0.0704 & $\begin{array}{l}0.1018 \\
(0.224)\end{array}$ & $0.5429 * * *$ & $\begin{array}{l}0.0430 \\
(0.263)\end{array}$ & $\begin{array}{l}0.0828 \\
(0.171)\end{array}$ \\
\hline ILLIQ & $\begin{array}{c}-0.0511^{*} \\
(0.029)\end{array}$ & $\begin{array}{l}-0.0109 \\
(0.016)\end{array}$ & $\begin{array}{l}-0.0065 \\
(0.033)\end{array}$ & $\begin{array}{l}0.0747 \\
(0.071)\end{array}$ & $\begin{array}{l}0.0032 \\
(0.054)\end{array}$ & $\begin{array}{l}-0.0106 \\
(0.009)\end{array}$ \\
\hline MOM & $\begin{array}{l}0.7209 \\
(0.451)\end{array}$ & $\begin{array}{l}0.3395 \\
(0.387)\end{array}$ & $\begin{array}{l}0.3962 \\
(0.421)\end{array}$ & $\begin{array}{l}0.1954 \\
(0.368)\end{array}$ & $\begin{array}{c}0.9743 * * \\
(0.402)\end{array}$ & $\begin{array}{c}0.5473 * \\
(0.331)\end{array}$ \\
\hline Size & $\begin{array}{c}-0.1202^{* *} \\
(0.059)\end{array}$ & $\begin{array}{c}-0.1496^{* *} \\
(0.066)\end{array}$ & $\begin{array}{c}-0.1648^{*} \\
(0.091)\end{array}$ & $\begin{array}{c}-0.1425^{* *} \\
(0.065)\end{array}$ & $\begin{array}{c}-0.1308^{* *} \\
(0.064)\end{array}$ & $\begin{array}{c}-0.1119^{*} \\
(0.064)\end{array}$ \\
\hline VOL & $\begin{array}{l}0.0429 \\
(0.034)\end{array}$ & $\begin{array}{l}0.0109 \\
(0.025)\end{array}$ & $\begin{array}{l}-0.0064 \\
(0.033)\end{array}$ & $\begin{array}{r}-0.0166 \\
(0.028)\end{array}$ & $\begin{array}{l}0.0297 \\
(0.025)\end{array}$ & $\begin{array}{l}0.0382 \\
(0.024)\end{array}$ \\
\hline BM & $\begin{array}{l}0.1531 \\
(0.223)\end{array}$ & $\begin{array}{l}0.0095 \\
(0.080)\end{array}$ & $\begin{array}{l}0.0171 \\
(0.093)\end{array}$ & $\begin{array}{l}-0.3850 \\
(0.294)\end{array}$ & $\begin{array}{l}0.1371 \\
(0.152)\end{array}$ & $\begin{array}{l}-0.1582 \\
(0.123)\end{array}$ \\
\hline Log TNA & $\begin{array}{c}0.1207 * * \\
(0.061)\end{array}$ & $\begin{array}{c}0.1387^{* *} \\
(0.063)\end{array}$ & $\begin{array}{c}0.1558^{* *} \\
(0.063)\end{array}$ & $\begin{array}{c}0.1211^{* *} \\
(0.056)\end{array}$ & $\begin{array}{c}0.1692 * * \\
(0.078)\end{array}$ & $\begin{array}{l}0.1647^{*} \\
(0.099)\end{array}$ \\
\hline $\begin{array}{l}\text { Observations } \\
\text { R-squared }\end{array}$ & $\begin{array}{c}42,615 \\
0.002\end{array}$ & $\begin{array}{c}42,576 \\
0.003\end{array}$ & $\begin{array}{c}44,335 \\
0.003\end{array}$ & $\begin{array}{c}45,410 \\
0.003\end{array}$ & $\begin{array}{c}39,988 \\
0.003\end{array}$ & $\begin{array}{c}38,658 \\
0.001\end{array}$ \\
\hline
\end{tabular}

We compare the change in holdings of closed- and open-end funds around fire sale events. Estimates in Panel A are based on the whole (holdings) sample. Estimates in Panel B rely on a matched sample of open- and closed-end funds in which to each closed-end fund we match an open-end fund within 70$130 \%$ of the closed-end fund's size and that minimizes the sum of the absolute percentage differences in TNA, number of stocks, and exposure to the Fama-French factors and the momentum factor. The matching is performed with replacement. Quarter $t$ is the quarter of the fire sale, identified as in Coval and Stafford (2007). The dependent variable is a fund's change in quarterly holdings ( $\Delta \operatorname{shares}(t+$ $k)_{i, s, t}$ ) in the quarters preceding, during or following the fire sale, as indicated on top of each column, divided by the firm's number of shares outstanding at the beginning of the quarter. We divide $\Delta$ shares $(t+k)_{i, s, t}$ by the standard deviation of all $\Delta$ shares $(t+k)_{i, s, t}$ (including non fire sale stocks) of closed- and open-end funds during the sample period. All remaining variables are defined in the Appendix. All equations include time fixed effects and a constant whose coefficients are not reported. We present ordinary least squares estimates with errors double clustered at the fund and time level and corrected for heteroscedasticity. ${ }^{* * *}, * *, *$ denote significance at $1 \%, 5 \%$, and $10 \%$ levels, respectively. 
Table 5

Closed- and Open-end Funds' Trades in Placebo Fire Sale Stocks

Panel A. Matched Stocks

\begin{tabular}{|c|c|c|c|c|c|c|}
\hline & $\begin{array}{c}(1) \\
\Delta \text { Shares }(t-2) \\
\end{array}$ & $\begin{array}{c}(2) \\
\Delta \text { Shares (t-1) } \\
\end{array}$ & $\begin{array}{c}(3) \\
\Delta \text { Shares }(\mathrm{t}) \\
\end{array}$ & $\begin{array}{c}(4) \\
\Delta \text { Shares }(t+1) \\
\end{array}$ & $\begin{array}{c}(5) \\
\Delta \text { Shares }(t+2) \\
\end{array}$ & $\begin{array}{c}(6) \\
\Delta \text { Shares }(t+3)\end{array}$ \\
\hline Closed & $\begin{array}{l}-0.1073 \\
(0.102)\end{array}$ & $\begin{array}{l}0.1307 \\
(0.152)\end{array}$ & $\begin{array}{l}-0.1622 \\
(0.108)\end{array}$ & $\begin{array}{l}0.0395 \\
(0.073)\end{array}$ & $\begin{array}{l}0.0828 \\
(0.098)\end{array}$ & $\begin{array}{l}0.0379 \\
(0.076)\end{array}$ \\
\hline ILLIQ & $\begin{array}{l}-0.0153 \\
(0.016)\end{array}$ & $\begin{array}{l}0.0305 \\
(0.038)\end{array}$ & $\begin{array}{l}0.0545 \\
(0.050)\end{array}$ & $\begin{array}{r}-0.0157 \\
(0.018)\end{array}$ & $\begin{array}{l}-0.0225 \\
(0.016)\end{array}$ & $\begin{array}{l}0.0272 \\
(0.029)\end{array}$ \\
\hline MOM & $\begin{array}{c}0.9247 * * * \\
(0.302)\end{array}$ & $\begin{array}{c}0.4722 * * \\
(0.235)\end{array}$ & $\begin{array}{l}-0.0457 \\
(0.148)\end{array}$ & $\begin{array}{c}0.0707 \\
(0.174)\end{array}$ & $\begin{array}{l}-0.1345 \\
(0.185)\end{array}$ & $\begin{array}{c}0.2449 \\
(0.199)\end{array}$ \\
\hline Size & $\begin{array}{c}-0.0840 * * * \\
(0.030)\end{array}$ & $\begin{array}{c}-0.0869 * * * \\
(0.031)\end{array}$ & $\begin{array}{c}-0.1241 * * * \\
(0.027)\end{array}$ & $\begin{array}{c}-0.1069 * * * \\
(0.024)\end{array}$ & $\begin{array}{c}-0.1360 * * * \\
(0.031)\end{array}$ & $\begin{array}{c}-0.1122 * * * \\
(0.026)\end{array}$ \\
\hline VOL & $\begin{array}{c}0.0085 \\
(0.011)\end{array}$ & $\begin{array}{c}0.0173 \\
(0.012)\end{array}$ & $\begin{array}{c}0.0248^{* * *} \\
(0.010)\end{array}$ & $\begin{array}{c}0.0276^{* * *} \\
(0.010)\end{array}$ & $\begin{array}{c}0.0211^{* *} \\
(0.010)\end{array}$ & $\begin{array}{c}0.0149 * * \\
(0.007)\end{array}$ \\
\hline $\mathrm{BM}$ & $\begin{array}{c}-0.0779 \\
(0.077)\end{array}$ & $\begin{array}{l}0.1133 \\
(0.075)\end{array}$ & $\begin{array}{l}0.0903 \\
(0.069)\end{array}$ & $\begin{array}{l}0.0179 \\
(0.108)\end{array}$ & $\begin{array}{l}0.0884 \\
(0.099)\end{array}$ & $\begin{array}{c}0.2188 * * * \\
(0.061)\end{array}$ \\
\hline Log TNA & $\begin{array}{c}0.0706^{* * * *} \\
(0.017)\end{array}$ & $\begin{array}{c}0.0773 * * * \\
(0.022)\end{array}$ & $\begin{array}{c}0.0779 * * * \\
(0.021)\end{array}$ & $\begin{array}{c}0.0904^{* * * *} \\
(0.023)\end{array}$ & $\begin{array}{c}0.1087 * * * \\
(0.025)\end{array}$ & $\begin{array}{c}0.0579 * * * \\
(0.022)\end{array}$ \\
\hline $\mathrm{N}$ & 143,619 & 143,355 & 143,787 & 141,842 & 141,082 & 139,396 \\
\hline
\end{tabular}


Panel B. Discretionary Sales

\begin{tabular}{|c|c|c|c|c|c|c|}
\hline & $\begin{array}{c}(1) \\
\Delta \text { Shares (t-2) } \\
\end{array}$ & $\begin{array}{c}(2) \\
\Delta \text { Shares (t-1) } \\
\end{array}$ & $\begin{array}{c}(3) \\
\Delta \text { Shares }(\mathrm{t}) \\
\end{array}$ & $\begin{array}{c}(4) \\
\Delta \text { Shares }(t+1) \\
\end{array}$ & $\begin{array}{c}(5) \\
\Delta \text { Shares }(\mathrm{t}+2) \\
\end{array}$ & $\begin{array}{c}(6) \\
\Delta \text { Shares }(\mathrm{t}+3)\end{array}$ \\
\hline Closed & $\begin{array}{c}-0.02438 \\
(0.166)\end{array}$ & $\begin{array}{c}-0.0266 \\
(0.118)\end{array}$ & $\begin{array}{l}0.0789 \\
(0.431)\end{array}$ & $\begin{array}{l}0.0283 \\
(0.128)\end{array}$ & $\begin{array}{l}0.0468 \\
(0.091)\end{array}$ & $\begin{array}{l}0.0952 \\
(0.076)\end{array}$ \\
\hline ILLIQ & $\begin{array}{c}-0.0231 * * * \\
(0.008)\end{array}$ & $\begin{array}{c}-0.0230 * * \\
(0.010)\end{array}$ & $\begin{array}{l}-0.0466 \\
(0.038)\end{array}$ & $\begin{array}{l}-0.0372 \\
(0.039)\end{array}$ & $\begin{array}{l}-0.0402 \\
(0.031)\end{array}$ & $\begin{array}{l}-0.0056 \\
(0.018)\end{array}$ \\
\hline MOM & $\begin{array}{c}0.6377^{*} \\
(0.377)\end{array}$ & $\begin{array}{c}0.7396^{* * * *} \\
(0.274)\end{array}$ & $\begin{array}{c}0.6181 * * \\
(0.313)\end{array}$ & $\begin{array}{l}0.7277 \\
(0.514)\end{array}$ & $\begin{array}{l}0.0833 \\
(0.282)\end{array}$ & $\begin{array}{r}-0.1043 \\
(0.178)\end{array}$ \\
\hline Size & $\begin{array}{c}-0.1076^{* *} \\
(0.048)\end{array}$ & $\begin{array}{c}-0.1024 * * * \\
(0.035)\end{array}$ & $\begin{array}{c}-0.0957 * * \\
(0.039)\end{array}$ & $\begin{array}{c}-0.0653^{*} \\
(0.037)\end{array}$ & $\begin{array}{c}-0.1058^{* * * *} \\
(0.040)\end{array}$ & $\begin{array}{c}-0.1077 * * * \\
(0.029)\end{array}$ \\
\hline VOL & $\begin{array}{c}0.0605^{*} \\
(0.033)\end{array}$ & $\begin{array}{c}0.0338 * * \\
(0.017)\end{array}$ & $\begin{array}{l}0.0494 \\
(0.041)\end{array}$ & $\begin{array}{c}0.0885^{*} \\
(0.048)\end{array}$ & $\begin{array}{l}0.0332 \\
(0.034)\end{array}$ & $\begin{array}{c}0.0317^{*} \\
(0.017)\end{array}$ \\
\hline BM & $\begin{array}{l}0.1032 \\
(0.077)\end{array}$ & $\begin{array}{c}0.1361 * * * \\
(0.052)\end{array}$ & $\begin{array}{l}0.3164 \\
(0.285)\end{array}$ & $\begin{array}{c}0.1734 * * \\
(0.078)\end{array}$ & $\begin{array}{l}0.3305 \\
(0.231)\end{array}$ & $\begin{array}{l}0.0673 \\
(0.065)\end{array}$ \\
\hline Log TNA & $\begin{array}{c}0.1533 * * * \\
(0.039)\end{array}$ & $\begin{array}{c}0.1131 * * * \\
(0.023)\end{array}$ & $\begin{array}{c}0.1123 * * \\
(0.053)\end{array}$ & $\begin{array}{c}0.0965^{*} \\
(0.056)\end{array}$ & $\begin{array}{c}0.0825 * * \\
(0.037)\end{array}$ & $\begin{array}{c}0.0806^{* * *} \\
(0.026)\end{array}$ \\
\hline $\begin{array}{l}\mathrm{N} \\
\mathrm{R} \text {-squared }\end{array}$ & $\begin{array}{c}155,780 \\
0.002\end{array}$ & $\begin{array}{c}154,975 \\
0.002\end{array}$ & $\begin{array}{c}154,219 \\
0.001\end{array}$ & $\begin{array}{c}153,311 \\
0.001\end{array}$ & $\begin{array}{c}150,685 \\
0.002\end{array}$ & $\begin{array}{c}147,189 \\
0.002\end{array}$ \\
\hline
\end{tabular}

We compare the change in holdings of closed- and open-end funds in different sets of stocks. In Panel A, we consider stocks that match each fire sale stock in quarter $t$, the quarter of the fire sale, identified as in Coval and Stafford (2007). The matching is performed with replacement and requires that the matched stock is in the same two-digit industry, within $70-130 \%$ of size of the fire sale stock, and that minimizes the absolute percentage differences in size and book to market ratio. In Panel B, we consider stocks with large discretionary sales. Following Coval and Stafford (2007), for each stock, we define Disc Sales $_{s, t}=\sum_{i} \Delta$ Hold $_{i, s, t} /$ AvgVolume $_{s, t-12: t-6}$, that is, the ratio of the change in shares held by non-distressed open-end funds relative to the stock's trading volume. Stocks with Disc Sales below the $10^{\text {th }}$ percentile are considered to be stocks with large discretionary sales. The dependent variable is a fund's change in quarterly holdings $\left(\Delta \operatorname{shares}(t+k)_{i, s, t}\right)$ in the quarters preceding, during or following the fire sale or discretionary sale, as indicated on top of each column, divided by the firm's number of shares outstanding at the beginning of the quarter. We divide $\Delta \operatorname{shares}(t+k)_{i, s, t}$ by the standard deviation of all $\Delta$ shares $(t+k)_{i, s, t}$ of closed- and open-end funds during the sample period. All remaining variables are defined in the Appendix. All equations include time fixed effects and a constant whose coefficients are not reported. We present ordinary least squares estimates with errors double clustered at the fund and time level and corrected for heteroscedasticity. ***, **, * denote significance at $1 \%, 5 \%$, and $10 \%$ levels, respectively. 
Table 6

Stock Characteristics and Closed- and Open-End Funds' Trades in Fire Sales

\begin{tabular}{|c|c|c|c|c|c|c|}
\hline & $(1)$ & $(2)$ & (3) & (4) & $(5)$ & $(6)$ \\
\hline Closed & $\begin{array}{c}3.1279 * * * \\
(1.021)\end{array}$ & $\begin{array}{l}-0.4435 \\
(0.586)\end{array}$ & $\begin{array}{c}0.5130 * * * \\
(0.179)\end{array}$ & $\begin{array}{c}0.4472 * * \\
(0.192)\end{array}$ & $\begin{array}{c}0.5014 * * * \\
(0.178)\end{array}$ & $\begin{array}{c}2.1609 * * \\
(1.091)\end{array}$ \\
\hline Closed x Size & $\begin{array}{c}-0.3292 * * * \\
(0.113)\end{array}$ & & & & & $\begin{array}{c}-0.3159 * * * \\
(0.104)\end{array}$ \\
\hline Closed x VOL & & $\begin{array}{c}0.1005^{* *} \\
(0.049)\end{array}$ & & & & $\begin{array}{l}0.0849 * \\
(0.049)\end{array}$ \\
\hline $\begin{array}{l}\text { Closed x } \\
\text { ILLIQ }\end{array}$ & & & -0.0750 & & & -0.0925 \\
\hline Closed x BM & & & $(0.062)$ & $\begin{array}{l}0.0615 \\
(0.070)\end{array}$ & & $\begin{array}{c}(0.059) \\
0.0482 \\
(0.071)\end{array}$ \\
\hline Closed x MOM & & & & & $\begin{array}{l}0.0425 \\
(0.312)\end{array}$ & $\begin{array}{c}-0.0684 \\
(0.294)\end{array}$ \\
\hline Size & $\begin{array}{c}-0.1201 * * * \\
(0.029)\end{array}$ & $\begin{array}{c}-0.1512 * * * \\
(0.028)\end{array}$ & $\begin{array}{c}-0.1495^{* * *} \\
(0.028)\end{array}$ & $\begin{array}{c}-0.1502 * * * \\
(0.028)\end{array}$ & $\begin{array}{c}-0.1495 * * * \\
(0.028)\end{array}$ & $\begin{array}{c}-0.1228^{* * * *} \\
(0.029)\end{array}$ \\
\hline VOL & $\begin{array}{l}0.0038 \\
(0.014)\end{array}$ & $\begin{array}{l}-0.0011 \\
(0.014)\end{array}$ & $\begin{array}{l}0.0022 \\
(0.014)\end{array}$ & $\begin{array}{l}0.0022 \\
(0.014)\end{array}$ & $\begin{array}{l}0.0022 \\
(0.014)\end{array}$ & $\begin{array}{l}0.0015 \\
(0.014)\end{array}$ \\
\hline ILLIQ & $\begin{array}{l}0.0530 \\
(0.054)\end{array}$ & $\begin{array}{l}0.0561 \\
(0.054)\end{array}$ & $\begin{array}{l}0.0781 \\
(0.060)\end{array}$ & $\begin{array}{l}0.0566 \\
(0.054)\end{array}$ & $\begin{array}{l}0.0566 \\
(0.054)\end{array}$ & $\begin{array}{l}0.0794 \\
(0.060)\end{array}$ \\
\hline $\mathrm{BM}$ & $\begin{array}{l}0.0619 \\
(0.067)\end{array}$ & $\begin{array}{l}0.0599 \\
(0.066)\end{array}$ & $\begin{array}{l}0.0604 \\
(0.066)\end{array}$ & $\begin{array}{l}0.0425 \\
(0.065)\end{array}$ & $\begin{array}{l}0.0613 \\
(0.066)\end{array}$ & $\begin{array}{l}0.0440 \\
(0.065)\end{array}$ \\
\hline MOM & $\begin{array}{l}0.2422 \\
(0.184)\end{array}$ & $\begin{array}{l}0.2395 \\
(0.184)\end{array}$ & $\begin{array}{l}0.2414 \\
(0.184)\end{array}$ & $\begin{array}{l}0.2365 \\
(0.183)\end{array}$ & $\begin{array}{l}0.2405 \\
(0.184)\end{array}$ & $\begin{array}{l}0.2835 \\
(0.191)\end{array}$ \\
\hline Log TNA & $\begin{array}{c}0.1058 * * * \\
(0.025)\end{array}$ & $\begin{array}{c}0.1066 * * * \\
(0.025)\end{array}$ & $\begin{array}{c}0.1070 * * * \\
(0.025)\end{array}$ & $\begin{array}{c}0.1070 * * * \\
(0.025)\end{array}$ & $\begin{array}{c}0.1069 * * * \\
(0.025)\end{array}$ & $\begin{array}{c}0.1060 * * * \\
(0.025)\end{array}$ \\
\hline Observations & 152,543 & 152,543 & 152,543 & 152,543 & 152,543 & 152,543 \\
\hline R-squared & 0.002 & 0.002 & 0.002 & 0.002 & 0.002 & 0.002 \\
\hline
\end{tabular}

We compare the change in holdings of closed- and open-end funds in fire sale stocks with different characteristics. The dependent variable is a fund's change in quarterly holdings $\left(\Delta \operatorname{shares}(t+1)_{i, s, t}\right)$ in the quarter following the fire sale, identified as in Coval and Stafford (2007), divided by the firm's number of shares outstanding at the beginning of the quarter. We divide $\Delta \operatorname{shares}(t+1)_{i, s, t}$ by the standard deviation of all $\Delta$ shares $(t+1)_{i, s, t}$ of closed- and open-end funds (including non fire sale stocks) during the sample period. All remaining variables are defined in the Appendix. All equations include time fixed effects and a constant whose coefficients are not reported. We present ordinary least squares estimates with errors double clustered at the fund and time level and corrected for heteroscedasticity. $* * *, * *, *$ denote significance at $1 \%, 5 \%$, and $10 \%$ levels, respectively. 
Table 7

Open-end Funds' Flow Performance Sensitivity and Trades in Fire Sales

\begin{tabular}{|c|c|c|c|}
\hline & (1) & (2) & (3) \\
\hline Open & $\begin{array}{c}-0.3743 * \\
(0.193)\end{array}$ & $\begin{array}{c}-0.7142 * * * \\
(0.259)\end{array}$ & $\begin{array}{c}-0.4606^{* *} \\
(0.193)\end{array}$ \\
\hline Open x FPS & $\begin{array}{c}-0.1251^{* *} \\
(0.055)\end{array}$ & & \\
\hline Open x Tenure & & $\begin{array}{c}0.1883 * * \\
(0.093)\end{array}$ & \\
\hline Open x Institutional & & & $\begin{array}{c}0.3707^{*} \\
(0.211)\end{array}$ \\
\hline Size & $\begin{array}{c}-0.1501 * * * \\
(0.028)\end{array}$ & $\begin{array}{c}-0.1883 * * * \\
(0.029)\end{array}$ & $\begin{array}{c}-0.1607 * * * \\
(0.031)\end{array}$ \\
\hline VOL & $\begin{array}{l}0.0020 \\
(0.014)\end{array}$ & $\begin{array}{l}0.0197 \\
(0.016)\end{array}$ & $\begin{array}{l}0.0007 \\
(0.014)\end{array}$ \\
\hline ILLIQ & $\begin{array}{l}0.0565 \\
(0.054)\end{array}$ & $\begin{array}{l}0.0556 \\
(0.055)\end{array}$ & $\begin{array}{l}0.0563 \\
(0.054)\end{array}$ \\
\hline BM & $\begin{array}{l}0.0647 \\
(0.067)\end{array}$ & $\begin{array}{l}0.0442 \\
(0.082)\end{array}$ & $\begin{array}{l}0.0199 \\
(0.065)\end{array}$ \\
\hline MOM & $\begin{array}{l}0.2449 \\
(0.185)\end{array}$ & $\begin{array}{l}0.2221 \\
(0.243)\end{array}$ & $\begin{array}{l}0.2482 \\
(0.186)\end{array}$ \\
\hline Log TNA & $\begin{array}{c}0.1077 * * * \\
(0.025)\end{array}$ & $\begin{array}{c}0.1258 * * * \\
(0.029)\end{array}$ & $\begin{array}{c}0.1121 * * * \\
(0.028)\end{array}$ \\
\hline Observations & 151,384 & 103,699 & 133,509 \\
\hline R-squared & 0.002 & 0.002 & 0.002 \\
\hline
\end{tabular}

We explore how differences between open- and closed-end funds' trading in fire sale stocks vary with open-end funds' characteristics, which are related to their flow-performance sensitivity. Quarter $t+1$ is the quarter following the fire sale, identified as in Coval and Stafford (2007). The dependent variable is a fund's change in quarterly holdings $\left(\Delta \operatorname{shares}(t+1)_{i, s, t}\right)$ in the quarter following the fire sale, divided by the stock's total number of shares outstanding at the beginning of the quarter. We divide $\Delta$ shares $(t+1)_{i, s, t}$ by the standard deviation of all $\Delta$ shares $(t+1)_{i, s, t}$ of closed- and open-end funds (including non fire sale stocks) during the sample period. All remaining variables are defined in the Appendix. All equations include controls for time fixed effects and a constant whose coefficients are not reported. We present ordinary least squares estimates with errors double clustered at the fund and time level and corrected for heteroscedasticity. $* * *, * *, *$ denote significance at $1 \%, 5 \%$, and $10 \%$ levels, respectively. 
Table 8

Controlling for Funds' Financial Slack

\begin{tabular}{|c|c|c|c|c|c|c|}
\hline Sample & $\frac{(1)}{\text { Excluding if }}$ & $\frac{(2)}{\text { flows }<P 25}$ & (3) & (4) & (5) & (6) \\
\hline Open & $\begin{array}{c}-0.4153^{* *} \\
(0.180)\end{array}$ & $\begin{array}{c}-0.4019^{* *} \\
(0.178)\end{array}$ & & & & \\
\hline Closed & & & $\begin{array}{c}0.4485 * * * \\
(0.169)\end{array}$ & $\begin{array}{c}0.4868 * * \\
(0.190)\end{array}$ & $\begin{array}{c}0.4775 * * * \\
(0.180)\end{array}$ & $\begin{array}{c}0.4900 * * \\
(0.203)\end{array}$ \\
\hline Open x Past Flows & & $\begin{array}{l}0.5156 \\
(0.368)\end{array}$ & & & & \\
\hline Prior Exposure & & & $\begin{array}{l}0.0039 \\
(0.007)\end{array}$ & & & \\
\hline Closed x Leverage & & & & $\begin{array}{l}0.3502 \\
(1.433)\end{array}$ & & \\
\hline Fund ILLIQ & & & & & $\begin{array}{c}0.1450 * \\
(0.086)\end{array}$ & \\
\hline Cash & & & & & & $\begin{array}{c}1.0656^{*} \\
(0.578)\end{array}$ \\
\hline Size & $\begin{array}{c}-0.1859 * * * \\
(0.034)\end{array}$ & $\begin{array}{c}-0.1863 * * * \\
(0.034)\end{array}$ & $\begin{array}{c}-0.1270 * * * \\
(0.031)\end{array}$ & $\begin{array}{c}-0.1496 * * * \\
(0.028)\end{array}$ & $\begin{array}{c}-0.1424 * * * \\
(0.028)\end{array}$ & $\begin{array}{c}-0.1547 * * * \\
(0.030)\end{array}$ \\
\hline VOL & $\begin{array}{l}0.0116 \\
(0.015)\end{array}$ & $\begin{array}{l}0.0122 \\
(0.016)\end{array}$ & $\begin{array}{l}0.0047 \\
(0.015)\end{array}$ & $\begin{array}{l}0.0022 \\
(0.014)\end{array}$ & $\begin{array}{l}0.0023 \\
(0.014)\end{array}$ & $\begin{array}{l}0.0024 \\
(0.015)\end{array}$ \\
\hline ILLIQ & $\begin{array}{l}0.0855 \\
(0.071)\end{array}$ & $\begin{array}{l}0.0854 \\
(0.071)\end{array}$ & $\begin{array}{c}0.1241^{*} \\
(0.065)\end{array}$ & $\begin{array}{l}0.0565 \\
(0.054)\end{array}$ & $\begin{array}{l}0.0527 \\
(0.051)\end{array}$ & $\begin{array}{l}0.0525 \\
(0.054)\end{array}$ \\
\hline $\mathrm{BM}$ & $\begin{array}{l}0.0910 \\
(0.089)\end{array}$ & $\begin{array}{l}0.1060 \\
(0.092)\end{array}$ & $\begin{array}{l}0.0552 \\
(0.077)\end{array}$ & $\begin{array}{l}0.0611 \\
(0.066)\end{array}$ & $\begin{array}{l}0.0557 \\
(0.066)\end{array}$ & $\begin{array}{l}0.0614 \\
(0.073)\end{array}$ \\
\hline MOM & $\begin{array}{l}0.1781 \\
(0.226)\end{array}$ & $\begin{array}{l}0.1755 \\
(0.227)\end{array}$ & $\begin{array}{l}0.2392 \\
(0.203)\end{array}$ & $\begin{array}{l}0.2404 \\
(0.184)\end{array}$ & $\begin{array}{l}0.2438 \\
(0.183)\end{array}$ & $\begin{array}{l}0.2509 \\
(0.190)\end{array}$ \\
\hline Log TNA & $\begin{array}{c}0.1228 * * * \\
(0.027)\end{array}$ & $\begin{array}{c}0.1189 * * * \\
(0.027)\end{array}$ & $\begin{array}{c}0.1174 * * * \\
(0.025)\end{array}$ & $\begin{array}{c}0.1068 * * * \\
(0.025)\end{array}$ & $\begin{array}{c}0.1070 * * * \\
(0.024)\end{array}$ & $\begin{array}{c}0.1149 * * * \\
(0.025)\end{array}$ \\
\hline Observations & 117,802 & 116,328 & 119,480 & 152,543 & 152,542 & 130,989 \\
\hline $\mathrm{R}$-squared & 0.002 & 0.002 & 0.002 & 0.002 & 0.002 & 0.002 \\
\hline
\end{tabular}

We compare the change in holdings of closed- and open-end funds around fire sale events controlling for funds' financial slack. Quarter $t+1$ is the quarter following the fire sale identified as in Coval and Stafford (2007). The dependent variable is a fund's change in quarterly holdings $\left(\Delta \operatorname{shares}(t+1)_{i, s, t}\right)$ in the quarter following the fire sale, divided by the stock's total number of shares outstanding at the beginning of the quarter. We divide $\Delta$ shares $(t+1)_{i, s, t}$ by the standard deviation of all $\Delta$ shares $(t+1)_{i, s, t}$ of closed- and open-end funds (including non fire sale stocks) during the sample period. All remaining variables are defined in the Appendix. All equations include controls for time fixed effects and a constant whose coefficients are not reported. In columns 1 and 2 we exclude open-end funds with flows in the bottom quartile (in our sample of non-distressed funds). We present ordinary least squares estimates with errors double clustered at the fund and time level and corrected for heteroscedasticity. $* * *, * * *$ denote significance at $1 \%, 5 \%$, and $10 \%$ levels, respectively. 
Table 9

Additional Robustness Tests

\begin{tabular}{|c|c|c|c|c|c|c|c|}
\hline & (1) & (2) & (3) & (4) & (5) & (6) & (7) \\
\hline Sample & & & Comanagers & & & & \\
\hline Closed & & $\begin{array}{c}0.5631 * * * \\
(0.191)\end{array}$ & $\begin{array}{c}0.3735^{* *} \\
(0.166)\end{array}$ & $\begin{array}{c}0.5082 * * * \\
(0.176)\end{array}$ & $\begin{array}{c}0.5672 * * * \\
(0.189)\end{array}$ & & \\
\hline Open & $\begin{array}{c}-0.4678^{* *} \\
(0.218)\end{array}$ & & & & & $\begin{array}{c}-0.5830 * * * \\
(0.182)\end{array}$ & $\begin{array}{c}-0.6852 * * * \\
(0.215)\end{array}$ \\
\hline Open x Distressed Style & $\begin{array}{r}-0.2082 \\
(0.711)\end{array}$ & & & & & & \\
\hline Past Alpha & & $\begin{array}{l}0.1852 \\
(0.252)\end{array}$ & & & & & \\
\hline Closed x Discount & & & & $\begin{array}{l}0.1038 \\
(1.031)\end{array}$ & & & \\
\hline Expenses & & & & & $\begin{array}{c}0.1968 \\
(0.144)\end{array}$ & & \\
\hline $\begin{array}{l}\text { Open x High Man } \\
\text { Ownership }\end{array}$ & & & & & & $0.1041^{*}$ & \\
\hline & & & & & & $(0.061)$ & \\
\hline Open x High & & & & & & & 0.0941 \\
\hline Board Quality & & & & & & & $(0.157)$ \\
\hline Size & $\begin{array}{c}-0.1524 * * * \\
(0.029)\end{array}$ & $\begin{array}{c}-0.1491 * * * \\
(0.029)\end{array}$ & $\begin{array}{c}-0.0960 * * \\
(0.049)\end{array}$ & $\begin{array}{c}-0.1477 * * * \\
(0.028)\end{array}$ & $\begin{array}{c}-0.1498 * * * \\
(0.028)\end{array}$ & $\begin{array}{c}-0.1903 * * * \\
(0.036)\end{array}$ & $\begin{array}{c}-0.2316^{* * *} \\
(0.053)\end{array}$ \\
\hline VOL & $\begin{array}{l}0.0038 \\
(0.014)\end{array}$ & $\begin{array}{l}0.0024 \\
(0.014)\end{array}$ & $\begin{array}{l}-0.0105 \\
(0.018)\end{array}$ & $\begin{array}{l}0.0030 \\
(0.014)\end{array}$ & $\begin{array}{l}0.0025 \\
(0.014)\end{array}$ & $\begin{array}{l}0.0033 \\
(0.016)\end{array}$ & $\begin{array}{l}0.0075 \\
(0.026)\end{array}$ \\
\hline ILLIQ & $\begin{array}{l}0.0563 \\
(0.054)\end{array}$ & $\begin{array}{l}0.0819 \\
(0.053)\end{array}$ & $\begin{array}{l}0.0222 \\
(0.019)\end{array}$ & $\begin{array}{l}0.0556 \\
(0.054)\end{array}$ & $\begin{array}{l}0.0797 \\
(0.052)\end{array}$ & $\begin{array}{l}0.0554 \\
(0.054)\end{array}$ & $\begin{array}{l}0.0030 \\
(0.044)\end{array}$ \\
\hline $\mathrm{BM}$ & $\begin{array}{l}0.0369 \\
(0.069)\end{array}$ & $\begin{array}{l}0.0562 \\
(0.069)\end{array}$ & $\begin{array}{l}-0.0274 \\
(0.053)\end{array}$ & $\begin{array}{l}0.0541 \\
(0.066)\end{array}$ & $\begin{array}{l}0.0587 \\
(0.066)\end{array}$ & $\begin{array}{l}0.0071 \\
(0.077)\end{array}$ & $\begin{array}{l}0.0515 \\
(0.126)\end{array}$ \\
\hline MOM & $\begin{array}{l}0.1955 \\
(0.185)\end{array}$ & $\begin{array}{l}0.2615 \\
(0.194)\end{array}$ & $\begin{array}{l}-0.0961 \\
(0.222)\end{array}$ & $\begin{array}{l}0.2251 \\
(0.184)\end{array}$ & $\begin{array}{l}0.2470 \\
(0.184)\end{array}$ & $\begin{array}{l}0.3079 \\
(0.208)\end{array}$ & $\begin{array}{l}0.7187^{*} \\
(0.382)\end{array}$ \\
\hline Log TNA & $\begin{array}{c}0.1080^{* * *} \\
(0.026)\end{array}$ & $\begin{array}{c}0.1038^{* * *} \\
(0.025)\end{array}$ & $\begin{array}{l}0.0591 \\
(0.073)\end{array}$ & $\begin{array}{c}0.1070^{* * *} \\
(0.025)\end{array}$ & $\begin{array}{c}0.1095^{* * *} \\
(0.026)\end{array}$ & $\begin{array}{c}0.1221^{* * *} \\
(0.031)\end{array}$ & $\begin{array}{c}0.1499^{* *} \\
(0.070)\end{array}$ \\
\hline Observations & 151,098 & 148,059 & 13,562 & 151,312 & 151,429 & 113,179 & 42,958 \\
\hline R-squared & 0.002 & 0.002 & 0.002 & 0.002 & 0.002 & 0.002 & 0.004 \\
\hline
\end{tabular}

Quarter $t+1$ is the quarter following the fire sale identified as in Coval and Stafford (2007). The dependent variable is a fund's change in quarterly holdings $\left(\Delta \operatorname{shares}(t+1)_{i, s, t}\right)$ in the quarter following the fire sale, divided by the stock's total number of shares outstanding at the beginning of the quarter. We divide $\Delta$ shares $(t+1)_{i, s, t}$ by the standard deviation of all $\Delta$ shares $(t+1)_{i, s, t}$ of closed- and open-end funds (including non fire sale stocks) during the sample period. All remaining variables are defined in the Appendix. All equations include controls for time fixed effects and a constant whose coefficients are not reported. In column 3, we restrict the sample to open- and closed-end funds that are comanaged by the same manager. We present ordinary least squares estimates with errors double clustered at the fund and time level and corrected for heteroscedasticity. ***, **, * denote significance at $1 \%, 5 \%$, and $10 \%$ levels, respectively. 
Table 10

\section{Hedge Funds' Trades in Fire Sale Stocks}

\begin{tabular}{|c|c|c|c|c|c|c|c|}
\hline & $\begin{array}{c}(1) \\
\Delta \text { Shares }(\mathrm{t}-2)\end{array}$ & $\begin{array}{c}(2) \\
\Delta \text { Shares }(\mathrm{t}-1)\end{array}$ & $\begin{array}{c}(3) \\
\Delta \text { Shares (t) }\end{array}$ & $\begin{array}{c}(4) \\
\Delta \text { Shares }(\mathrm{t}+1)\end{array}$ & $\begin{array}{c}(5) \\
\Delta \text { Shares }(\mathrm{t}+2)\end{array}$ & $\begin{array}{c}(6) \\
\Delta \text { Shares }(\mathrm{t})\end{array}$ & $\begin{array}{c}(7) \\
\Delta \text { Shares }(t)\end{array}$ \\
\hline Share Restrictions & $\begin{array}{l}0.0141 \\
(0.022)\end{array}$ & $\begin{array}{l}0.0292 \\
(0.019)\end{array}$ & $\begin{array}{c}0.0804 * * \\
(0.038)\end{array}$ & $\begin{array}{l}0.0390 \\
(0.026)\end{array}$ & $\begin{array}{l}0.0142 \\
(0.022)\end{array}$ & $\begin{array}{c}0.3352 * * \\
(0.143)\end{array}$ & $\begin{array}{l}-0.0015 \\
(0.026)\end{array}$ \\
\hline Share Restrictions x Size & & & & & & $\begin{array}{c}-0.0346^{* *} \\
(0.015)\end{array}$ & \\
\hline Share Restrictions x Vol & & & & & & & $\begin{array}{c}0.0088^{* *} \\
(0.004)\end{array}$ \\
\hline Size & $\begin{array}{c}-0.1898 * * * \\
(0.019)\end{array}$ & $\begin{array}{c}-0.1705^{* * *} \\
(0.016)\end{array}$ & $\begin{array}{c}-0.2325^{* * *} \\
(0.025)\end{array}$ & $\begin{array}{c}-0.2114 * * * \\
(0.019)\end{array}$ & $\begin{array}{c}-0.2009 * * * \\
(0.016)\end{array}$ & $\begin{array}{c}-0.1841 * * * \\
(0.031)\end{array}$ & $\begin{array}{c}-0.2311^{* * *} \\
(0.025)\end{array}$ \\
\hline Vol & $\begin{array}{c}0.0316^{* * *} \\
(0.005)\end{array}$ & $\begin{array}{c}0.0215 * * * \\
(0.004)\end{array}$ & $\begin{array}{c}0.0268 * * * \\
(0.006)\end{array}$ & $\begin{array}{c}0.0264 * * * \\
(0.005)\end{array}$ & $\begin{array}{c}0.0230 * * * \\
(0.005)\end{array}$ & $\begin{array}{c}0.0266^{* * *} \\
(0.006)\end{array}$ & $\begin{array}{c}0.0152 * \\
(0.009)\end{array}$ \\
\hline ILLIQ & $\begin{array}{l}-0.0093 \\
(0.008)\end{array}$ & $\begin{array}{c}-0.0127 * * * \\
(0.004)\end{array}$ & $\begin{array}{c}-0.0212 * * * \\
(0.007)\end{array}$ & $\begin{array}{c}-0.0166^{* * *} \\
(0.003)\end{array}$ & $\begin{array}{c}-0.0226 * * * \\
(0.003)\end{array}$ & $\begin{array}{c}-0.0206^{* * *} \\
(0.007)\end{array}$ & $\begin{array}{c}-0.0212 * * * \\
(0.007)\end{array}$ \\
\hline $\mathrm{BM}$ & $\begin{array}{l}0.0091 * \\
(0.005)\end{array}$ & $\begin{array}{l}0.0001 \\
(0.003)\end{array}$ & $\begin{array}{l}-0.0009 \\
(0.007)\end{array}$ & $\begin{array}{l}-0.0016 \\
(0.002)\end{array}$ & $\begin{array}{l}-0.0016 \\
(0.004)\end{array}$ & $\begin{array}{l}-0.0007 \\
(0.007)\end{array}$ & $\begin{array}{l}-0.0009 \\
(0.007)\end{array}$ \\
\hline MOM & $\begin{array}{l}0.0759 \\
(0.094)\end{array}$ & $\begin{array}{l}0.1356 \\
(0.100)\end{array}$ & $\begin{array}{l}0.0092 \\
(0.063)\end{array}$ & $\begin{array}{l}-0.0561 \\
(0.059)\end{array}$ & $\begin{array}{r}-0.0575 \\
(0.061)\end{array}$ & $\begin{array}{l}0.0124 \\
(0.063)\end{array}$ & $\begin{array}{l}0.0118 \\
(0.063)\end{array}$ \\
\hline Log TNA & $\begin{array}{c}0.0222 * \\
(0.012)\end{array}$ & $\begin{array}{c}0.0224 * * \\
(0.011)\end{array}$ & $\begin{array}{c}0.0353 * * \\
(0.015)\end{array}$ & $\begin{array}{c}0.0286^{* * * *} \\
(0.010)\end{array}$ & $\begin{array}{c}0.0247 * * \\
(0.012)\end{array}$ & $\begin{array}{c}0.0371 * * \\
(0.015)\end{array}$ & $\begin{array}{c}0.0352 * * \\
(0.015)\end{array}$ \\
\hline Observations & 69,502 & 68,624 & 69,993 & 69,971 & 69,381 & 69,993 & 69,993 \\
\hline R-squared & 0.046 & 0.042 & 0.052 & 0.043 & 0.043 & 0.052 & 0.052 \\
\hline
\end{tabular}

We explore how the change in holdings of hedge funds varies around fire sale events. Share Restrictions is the sum of the number of days in the lock up, redemption notice and payout periods, divided by 100. Quarter $t$ is the quarter of the fire sale identified as in Coval and Stafford (2007). The dependent variable is a fund's change in quarterly holdings $\left(\Delta\right.$ shares $\left.(t+k)_{i, s, t}\right)$ in the quarters preceding, during or following the fire sale, as indicated on top of each column, divided by the firm's number of share

outstanding at the beginning of the quarter. We divide $\Delta$ shares $(t+k)_{i, s, t}$ by the standard deviation of all $\Delta s h a r e s(t+k)_{i, s, t}$ of hedge funds (including non fire sale stocks) during the sample period. All remaining variables are defined in the Appendix. All equations include time fixed effects and a constant whose coefficients are not reported. We present ordinary least squares estimates with errors double clustered at the fund and time level and corrected for heteroscedasticity. $* * *, * *, *$ denote significance at $1 \%, 5 \%$, and $10 \%$ levels, respectively. 
Table 11

Closed- and Open-end Funds' Exposure to Aggregate Mispricing

\begin{tabular}{|c|c|c|c|c|c|c|c|c|c|c|}
\hline Portfolio & $\begin{array}{l}(1) \\
\text { Small }\end{array}$ & $\begin{array}{c}(2) \\
\text { High Vol }\end{array}$ & $\begin{array}{c}(3) \\
\text { Young }\end{array}$ & $\begin{array}{c}(4) \\
\text { Low BM }\end{array}$ & $\begin{array}{c}5) \\
\text { High R\&D }\end{array}$ & $\begin{array}{c}(6) \\
\text { High External }\end{array}$ & $\begin{array}{c}(7) \\
\text { Low Sales }\end{array}$ & $\begin{array}{c}(8) \\
\text { Nonpayer }\end{array}$ & $\begin{array}{c}(9) \\
\text { Nonprofitable }\end{array}$ & $\begin{array}{c}(10) \\
\text { High BM } \\
\text { (Distress) }\end{array}$ \\
\hline Portfolio x Neg Sent x Closed & $\begin{array}{c}0.0627 * * * \\
(0.020)\end{array}$ & $\begin{array}{c}0.0605^{* * * *} \\
(0.022)\end{array}$ & $\begin{array}{c}0.0988^{* * * *} \\
(0.032)\end{array}$ & $\begin{array}{c}0.0806^{* *} \\
(0.032)\end{array}$ & $\begin{array}{c}0.0555^{* *} \\
(0.026)\end{array}$ & $\begin{array}{c}0.0710^{* * *} \\
(0.023)\end{array}$ & $\begin{array}{c}0.0535 * * \\
(0.025)\end{array}$ & $\begin{array}{c}0.0894 * * * \\
(0.029)\end{array}$ & $\begin{array}{c}0.0728^{* * *} \\
(0.022)\end{array}$ & $\begin{array}{c}0.0365^{* * *} \\
(0.011)\end{array}$ \\
\hline Portfolio x Closed & $\begin{array}{c}0.0483 * * * \\
(0.014)\end{array}$ & $\begin{array}{l}-0.0002 \\
(0.020)\end{array}$ & $\begin{array}{l}0.0019 \\
(0.025)\end{array}$ & $\begin{array}{l}-0.0494 \\
(0.031)\end{array}$ & $\begin{array}{l}-0.0263 \\
(0.021)\end{array}$ & $\begin{array}{l}0.0037 \\
(0.019)\end{array}$ & $\begin{array}{l}0.0219 \\
(0.022)\end{array}$ & $\begin{array}{l}0.0034 \\
(0.026)\end{array}$ & $\begin{array}{l}0.0132 \\
(0.019)\end{array}$ & $\begin{array}{c}0.0754 * * * \\
(0.012)\end{array}$ \\
\hline Portfolio x Neg Sent & $\begin{array}{l}0.0332 \\
(0.038)\end{array}$ & $\begin{array}{l}0.0171 \\
(0.025)\end{array}$ & $\begin{array}{l}0.0469 \\
(0.040)\end{array}$ & $\begin{array}{c}0.0874 * * * \\
(0.033)\end{array}$ & $\begin{array}{l}0.0356 \\
(0.024)\end{array}$ & $\begin{array}{l}0.0315 \\
(0.025)\end{array}$ & $\begin{array}{l}0.0094 \\
(0.031)\end{array}$ & $\begin{array}{l}0.0404 \\
(0.040)\end{array}$ & $\begin{array}{l}0.0318 \\
(0.028)\end{array}$ & $\begin{array}{l}0.0374 \\
(0.029)\end{array}$ \\
\hline Portfolio & $\begin{array}{l}0.0544 \\
(0.034)\end{array}$ & $\begin{array}{c}0.0433^{*} \\
(0.024)\end{array}$ & $\begin{array}{l}0.0550 \\
(0.038)\end{array}$ & $\begin{array}{c}0.0701^{* *} \\
(0.030)\end{array}$ & $\begin{array}{c}0.0520 * * * \\
(0.020)\end{array}$ & $\begin{array}{l}0.0408^{*} \\
(0.023)\end{array}$ & $\begin{array}{c}0.0642 * * \\
(0.028)\end{array}$ & $\begin{array}{c}0.0784 * * \\
(0.038)\end{array}$ & $\begin{array}{c}0.0437 * \\
(0.026)\end{array}$ & $\begin{array}{c}0.0410^{* *} \\
(0.016)\end{array}$ \\
\hline Neg Sent & $\begin{array}{l}0.0027^{*} \\
(0.002)\end{array}$ & $\begin{array}{l}0.0028^{*} \\
(0.002)\end{array}$ & $\begin{array}{l}0.0030^{*} \\
(0.002)\end{array}$ & $\begin{array}{l}0.0031^{*} \\
(0.002)\end{array}$ & $\begin{array}{c}0.0029^{*} \\
(0.002)\end{array}$ & $\begin{array}{l}0.0031 * \\
(0.002)\end{array}$ & $\begin{array}{l}0.0025 \\
(0.002)\end{array}$ & $\begin{array}{l}0.0027 * \\
(0.002)\end{array}$ & $\begin{array}{l}0.0030^{*} \\
(0.002)\end{array}$ & $\begin{array}{l}0.0021 \\
(0.002)\end{array}$ \\
\hline Closed & $\begin{array}{c}-0.0083 * * * \\
(0.001)\end{array}$ & $\begin{array}{c}-0.0082 * * * \\
(0.001)\end{array}$ & $\begin{array}{c}-0.0081 * * * \\
(0.001)\end{array}$ & $\begin{array}{c}-0.0084 * * * \\
(0.001)\end{array}$ & $\begin{array}{c}-0.0079 * * * \\
(0.001)\end{array}$ & $\begin{array}{c}-0.0082^{* * * *} \\
(0.001)\end{array}$ & $\begin{array}{c}-0.0082 * * * \\
(0.001)\end{array}$ & $\begin{array}{c}-0.0080 * * * \\
(0.001)\end{array}$ & $\begin{array}{c}-0.0081 * * * \\
(0.001)\end{array}$ & $\begin{array}{c}-0.0088^{* * *} \\
(0.001)\end{array}$ \\
\hline Market & $\begin{array}{c}0.9723^{* * *} \\
(0.017)\end{array}$ & $\begin{array}{c}0.9433^{* * * *} \\
(0.019)\end{array}$ & $\begin{array}{c}0.9482 * * * \\
(0.019)\end{array}$ & $\begin{array}{c}0.9366^{* * * *} \\
(0.018)\end{array}$ & $\begin{array}{c}0.9380^{* * * *} \\
(0.019)\end{array}$ & $\begin{array}{c}0.9488^{* * * *} \\
(0.018)\end{array}$ & $\begin{array}{c}0.9519 * * * \\
(0.017)\end{array}$ & $\begin{array}{c}0.9478 * * * \\
(0.017)\end{array}$ & $\begin{array}{c}0.9484^{* * *} \\
(0.018)\end{array}$ & $\begin{array}{c}0.9522 * * * \\
(0.018)\end{array}$ \\
\hline Market x Closed & $\begin{array}{c}-0.2963 * * * \\
(0.026)\end{array}$ & $\begin{array}{c}-0.3041 * * * \\
(0.024)\end{array}$ & $\begin{array}{c}-0.3041 * * * \\
(0.025)\end{array}$ & $\begin{array}{c}-0.2797 * * * \\
(0.024)\end{array}$ & $\begin{array}{c}-0.2844 * * * \\
(0.023)\end{array}$ & $\begin{array}{c}-0.3020^{* * *} \\
(0.025)\end{array}$ & $\begin{array}{c}-0.3093^{* * *} \\
(0.026)\end{array}$ & $\begin{array}{c}-0.3025^{* * *} \\
(0.025)\end{array}$ & $\begin{array}{c}-0.3082 * * * \\
(0.025)\end{array}$ & $\begin{array}{c}-0.3130^{* * * *} \\
(0.025)\end{array}$ \\
\hline Neg Sent x Closed & $\begin{array}{l}0.0014 \\
(0.001)\end{array}$ & $\begin{array}{l}0.0018 \\
(0.001)\end{array}$ & $\begin{array}{l}0.0017 \\
(0.001)\end{array}$ & $\begin{array}{c}0.0027^{* *} \\
(0.001)\end{array}$ & $\begin{array}{l}0.0019 \\
(0.001)\end{array}$ & $\begin{array}{l}0.0016 \\
(0.001)\end{array}$ & $\begin{array}{l}0.0019 \\
(0.001)\end{array}$ & $\begin{array}{l}0.0014 \\
(0.001)\end{array}$ & $\begin{array}{l}0.0013 \\
(0.001)\end{array}$ & $\begin{array}{l}0.0015 \\
(0.001)\end{array}$ \\
\hline Constant & $\begin{array}{c}0.0018^{* * *} \\
(0.001)\end{array}$ & $\begin{array}{c}0.0021^{* * *} \\
(0.001)\end{array}$ & $\begin{array}{c}0.0023 * * * \\
(0.001)\end{array}$ & $\begin{array}{c}0.0024 * * * \\
(0.001)\end{array}$ & $\begin{array}{c}0.0018^{* * * *} \\
(0.001)\end{array}$ & $\begin{array}{c}0.0021 * * * \\
(0.001)\end{array}$ & $\begin{array}{c}0.0019 * * * \\
(0.001)\end{array}$ & $\begin{array}{c}0.0018^{* * * *} \\
(0.001)\end{array}$ & $\begin{array}{c}0.0021 * * * \\
(0.001)\end{array}$ & $\begin{array}{c}0.0022 * * * \\
(0.001)\end{array}$ \\
\hline $\mathrm{N}$ & 272,373 & 272,373 & 272,373 & 272,373 & 272,373 & 272,373 & 272,373 & 272,373 & 272,373 & 272,373 \\
\hline $\mathrm{R}$-squared & 0.568 & 0.567 & 0.568 & 0.568 & 0.567 & 0.567 & 0.568 & 0.570 & 0.568 & 0.568 \\
\hline
\end{tabular}

The dependent variable is the monthly return of fund $i$. On top of each column, we indicate the portfolio of potentially mispriced stocks we consider in that specification. Portfolios are formed once per year using market equity, age, and volatility at the end of June of year $t$, and accounting data at the fiscal year-end of calendar year $t-1$. Portfolios are constructed based on NYSE decile breakpoints. Portfolio is the equally weighted monthly return of a given portfolio of stocks. Market is the value-weighted excess market return of all NYSE, AMEX, and NASDAQ stocks, which we obtain from Ken French's website. Neg Sent is a dummy variable that takes value equal to one during periods of negative sentiment, defined as in Baker and Wurgler (2007). All remaining variables, including the definition of firm characteristics used for the portfolio construction, are defined in the Appendix. We present ordinary least squares estimates with errors double clustered at the fund and time level and corrected for heteroscedasticity. $* * * * *, *$ denote significance at $1 \%, 5 \%$, and $10 \%$ levels, respectively. 
Table 12

Closed- and Open-end Funds' Exposure to Aggregate Mispricing: Robustness

\begin{tabular}{|c|c|c|c|c|c|c|}
\hline & (1) & (2) & (3) & (4) & $(5)$ & $(6)$ \\
\hline \multirow[t]{2}{*}{ Dependent variable: } & \multicolumn{5}{|c|}{ Monthly Return } & $\Delta$ holdings $(\%)$ \\
\hline & & & & Michigan & $\mathrm{HJ}$ & \\
\hline Small x Neg Sent $\mathrm{x}$ & $0.0716 * * *$ & $0.0476 * * *$ & $0.0481 * * *$ & $0.0603 * * *$ & & \\
\hline & $(0.021)$ & $(0.014)$ & $(0.014)$ & $(0.022)$ & & \\
\hline Small x Closed & $\begin{array}{c}0.0442 * * * \\
(0.010)\end{array}$ & $\begin{array}{c}0.0409 * * * \\
(0.015)\end{array}$ & $\begin{array}{c}0.0410 * * * \\
(0.015)\end{array}$ & $\begin{array}{c}0.0537 * * * \\
(0.016)\end{array}$ & & \\
\hline UMO x Closed & & & & & $\begin{array}{c}0.1215 * * * \\
(0.025)\end{array}$ & \\
\hline Small x Neg Sent & $\begin{array}{l}0.0326 \\
(0.037)\end{array}$ & $\begin{array}{c}0.0440 * * * \\
(0.005)\end{array}$ & $\begin{array}{c}0.0438 * * * \\
(0.005)\end{array}$ & $\begin{array}{l}0.0318 \\
(0.035)\end{array}$ & & \\
\hline Small & $\begin{array}{l}0.0546 \\
(0.034)\end{array}$ & $\begin{array}{c}0.0563 * * * \\
(0.006)\end{array}$ & $\begin{array}{c}0.0563 * * * \\
(0.006)\end{array}$ & $\begin{array}{c}0.0586^{* *} \\
(0.028)\end{array}$ & & \\
\hline Neg Sent & $\begin{array}{c}0.0026^{*} \\
(0.002)\end{array}$ & $\begin{array}{c}0.0026 * * * \\
(0.000)\end{array}$ & $\begin{array}{c}0.0026^{* * * *} \\
(0.000)\end{array}$ & $\begin{array}{l}-0.0009 \\
(0.001)\end{array}$ & & $\begin{array}{l}-1.6608 \\
(2.029)\end{array}$ \\
\hline UMO & & & & & $\begin{array}{l}0.0023 \\
(0.024)\end{array}$ & \\
\hline Closed & $\begin{array}{c}-0.0086^{* * *} \\
(0.001)\end{array}$ & $\begin{array}{c}-0.0080^{* * *} \\
(0.000)\end{array}$ & $\begin{array}{c}-0.0080 * * * \\
(0.000)\end{array}$ & $\begin{array}{c}-0.0075^{* * *} \\
(0.001)\end{array}$ & $\begin{array}{c}-0.0085^{* * *} \\
(0.001)\end{array}$ & $\begin{array}{c}-1.9796^{* *} \\
(0.850)\end{array}$ \\
\hline Market & $\begin{array}{c}0.9725 * * * \\
(0.017)\end{array}$ & $\begin{array}{c}0.9804 * * * \\
(0.007)\end{array}$ & $\begin{array}{c}0.9822 * * * \\
(0.009)\end{array}$ & $\begin{array}{c}0.9633 * * * \\
(0.018)\end{array}$ & $\begin{array}{c}0.9655 * * * \\
(0.022)\end{array}$ & \\
\hline Market x Closed & $\begin{array}{c}-0.2969^{* * *} \\
(0.026)\end{array}$ & $\begin{array}{c}-0.3139 * * * \\
(0.026)\end{array}$ & $\begin{array}{c}-0.3198 * * * \\
(0.031)\end{array}$ & $\begin{array}{c}-0.2947 * * * \\
(0.027)\end{array}$ & $\begin{array}{c}-0.2428 * * * \\
(0.020)\end{array}$ & \\
\hline PS LIQ & $\begin{array}{l}-0.0025 \\
(0.017)\end{array}$ & $\begin{array}{l}-0.0017 \\
(0.002)\end{array}$ & $\begin{array}{r}-0.0022 \\
(0.002)\end{array}$ & $\begin{array}{r}-0.0013 \\
(0.017)\end{array}$ & $\begin{array}{l}0.0007 \\
(0.018)\end{array}$ & \\
\hline PS LIQ x Closed & $\begin{array}{c}0.0509^{* * * *} \\
(0.018)\end{array}$ & $\begin{array}{c}0.0520 * * * \\
(0.010)\end{array}$ & $\begin{array}{c}0.0537 * * * \\
(0.009)\end{array}$ & $\begin{array}{c}0.0451 * * * \\
(0.017)\end{array}$ & $\begin{array}{c}0.0511 * * * \\
(0.015)\end{array}$ & \\
\hline Mom & & $\begin{array}{c}0.0273 * * * \\
(0.005)\end{array}$ & $\begin{array}{c}0.0271^{* * * *} \\
(0.004)\end{array}$ & & & \\
\hline Mom x Closed & & $\begin{array}{c}-0.0576^{* * *} \\
(0.012)\end{array}$ & $\begin{array}{c}-0.0569 * * * \\
(0.012)\end{array}$ & & & \\
\hline Market x Neg Sent & & & $\begin{array}{c}-0.0049 \\
(0.006)\end{array}$ & & & \\
\hline $\begin{array}{l}\text { Market x Neg Sent x } \\
\text { Closed }\end{array}$ & & & $\begin{array}{l}0.0143 \\
(0.022)\end{array}$ & & & \\
\hline Neg Sent x Closed & $\begin{array}{l}0.0013 \\
(0.001)\end{array}$ & $\begin{array}{c}0.0012 * * \\
(0.000)\end{array}$ & $\begin{array}{c}0.0012^{* *} \\
(0.001)\end{array}$ & $\begin{array}{l}-0.0001 \\
(0.001)\end{array}$ & & $\begin{array}{l}3.8624 * * \\
(1.602)\end{array}$ \\
\hline Constant & $\begin{array}{c}0.0018 * * * \\
(0.001)\end{array}$ & $\begin{array}{c}0.0015 * * * \\
(0.000)\end{array}$ & $\begin{array}{l}0.0016^{* * * *} \\
(0.000)\end{array}$ & $\begin{array}{c}0.0027 * * * \\
(0.001)\end{array}$ & $\begin{array}{c}0.0030 * * * \\
(0.001)\end{array}$ & $\begin{array}{c}3.8328 * * * \\
(1.390)\end{array}$ \\
\hline Observations & 272,373 & 272,373 & 272,373 & 272,373 & 272,373 & 17,348 \\
\hline R-squared & 0.568 & 0.569 & 0.569 & 0.567 & 0.562 & 0.000 \\
\hline
\end{tabular}

In columns 1 to 5 , the dependent variable is the monthly return of fund $i$. Small is the equally weighted monthly return of the portfolio of small stocks. The portfolio is formed once per year using market equity at the end of June of year $t$ and constructed using NYSE decile breakpoints. Stocks with market capitalization below this breakpoint are considered small. Market is the value-weighted excess market return of all NYSE, AMEX, and NASDAQ stocks, which we obtain from Ken French's website. In columns 1 to 3, Neg Sent is a dummy variable that takes value equal to one during periods of negative sentiment, defined as in Baker and Wurgler (2007). In column 4, negative sentiment is a dummy variable that takes value equal to one when the index of consumer sentiment compiled by the University of Michigan Survey Research Center is below the median. PS $L I Q$ is the liquidity factor of Pastor and Stambaugh (2003). In columns 2 and 3, Mom is the return of the momentum portfolio from Ken French's website. In column 5, UMO is the underpriced minus overpriced factor of Hirshleifer and Jiang (2010). In column 6, the dependent variable is the quarterly percentage change in fund $i$ 's total portfolio weight in small stocks, computed as the proportion of the portfolio held in small stocks using beginning of quarter stock prices. All remaining variables are defined in the Appendix. We present ordinary 
least squares estimates with errors double clustered at the fund and time level and corrected for heteroscedasticity. $* * *, * *, *$ denote significance at $1 \%, 5 \%$, and $10 \%$ levels, respectively. 
Table 13

\section{Hedge Funds' Exposure to Aggregate Mispricing}

\begin{tabular}{|c|c|c|c|c|c|c|c|c|c|c|}
\hline Portfolio & $\begin{array}{c}(1) \\
\text { Small }\end{array}$ & $\begin{array}{c}\text { (2) } \\
\text { High Vol }\end{array}$ & $\begin{array}{l}(3) \\
\text { Young }\end{array}$ & $\begin{array}{c}(4) \\
\text { Low BM }\end{array}$ & $\begin{array}{c}(5) \\
\text { High R\&D }\end{array}$ & $\begin{array}{c}(6) \\
\text { High External }\end{array}$ & $\begin{array}{c}(7) \\
\text { Low Sales }\end{array}$ & $\begin{array}{c}(8) \\
\text { Nonpayer }\end{array}$ & $\begin{array}{c}(9) \\
\text { Nonprofitable }\end{array}$ & $\begin{array}{c}(10) \\
\text { High BM (Distress) }\end{array}$ \\
\hline Portfolio x Neg Sent x Share Restrictions & $\begin{array}{c}0.0218 * * * \\
(0.007)\end{array}$ & $\begin{array}{c}0.0119 * * \\
(0.005)\end{array}$ & $\begin{array}{c}0.0161 * * \\
(0.008)\end{array}$ & $\begin{array}{c}0.0172 * * \\
(0.008)\end{array}$ & $\begin{array}{c}0.0126 * * \\
(0.005)\end{array}$ & $\begin{array}{l}0.0131 * * * \\
(0.005)\end{array}$ & $\begin{array}{c}0.0179 * * * \\
(0.006)\end{array}$ & $\begin{array}{c}0.0215 * * * \\
(0.007)\end{array}$ & $\begin{array}{c}0.0138 * * \\
(0.005)\end{array}$ & $\begin{array}{c}0.0147 * * * \\
(0.006)\end{array}$ \\
\hline Portfolio x Share Restrictions & $\begin{array}{l}-0.0082 \\
(0.007)\end{array}$ & $\begin{array}{l}-0.0066 \\
(0.005)\end{array}$ & $\begin{array}{r}-0.0082 \\
(0.008)\end{array}$ & $\begin{array}{l}-0.0129 \\
(0.008)\end{array}$ & $\begin{array}{c}-0.0086^{*} \\
(0.005)\end{array}$ & $\begin{array}{l}-0.0077 \\
(0.005)\end{array}$ & $\begin{array}{l}-0.0085 \\
(0.006)\end{array}$ & $\begin{array}{l}-0.0095 \\
(0.007)\end{array}$ & $\begin{array}{l}-0.0074 \\
(0.005)\end{array}$ & $\begin{array}{l}-0.0029 \\
(0.005)\end{array}$ \\
\hline Portfolio x Neg Sent & $\begin{array}{c}-0.1219^{* *} \\
(0.056)\end{array}$ & $\begin{array}{c}-0.0929 * * * \\
(0.036)\end{array}$ & $\begin{array}{c}-0.1099 * \\
(0.062)\end{array}$ & $\begin{array}{c}-0.1300^{* *} \\
(0.053)\end{array}$ & $\begin{array}{c}-0.0815^{* *} \\
(0.032)\end{array}$ & $\begin{array}{c}-0.0887^{* *} \\
(0.036)\end{array}$ & $\begin{array}{c}-0.1000^{* *} \\
(0.047)\end{array}$ & $\begin{array}{c}-0.1141^{*} \\
(0.059)\end{array}$ & $\begin{array}{c}-0.0905^{* *} \\
(0.040)\end{array}$ & $\begin{array}{r}-0.0452 \\
(0.041)\end{array}$ \\
\hline Portfolio & $\begin{array}{c}0.2003 * * * \\
(0.052)\end{array}$ & $\begin{array}{c}0.1522 * * * \\
(0.034)\end{array}$ & $\begin{array}{c}0.1854 * * * \\
(0.059)\end{array}$ & $\begin{array}{c}0.2360 * * * \\
(0.046)\end{array}$ & $\begin{array}{c}0.1544 * * * \\
(0.027)\end{array}$ & $\begin{array}{c}0.1539 * * * \\
(0.031)\end{array}$ & $\begin{array}{c}0.1751 * * * \\
(0.044)\end{array}$ & $\begin{array}{c}0.2130 * * * \\
(0.053)\end{array}$ & $\begin{array}{c}0.1581 * * * \\
(0.036)\end{array}$ & $\begin{array}{c}0.0836^{* *} \\
(0.039)\end{array}$ \\
\hline Neg Sent & $\begin{array}{c}0.0026^{* *} \\
(0.001)\end{array}$ & $\begin{array}{c}0.0029 * * \\
(0.001)\end{array}$ & $\begin{array}{c}0.0032 * * \\
(0.002)\end{array}$ & $\begin{array}{r}0.0030^{*} \\
(0.002)\end{array}$ & $\begin{array}{c}0.0026^{*} \\
(0.001)\end{array}$ & $\begin{array}{c}0.0032 * * \\
(0.001)\end{array}$ & $\begin{array}{c}0.0026^{* *} \\
(0.001)\end{array}$ & $\begin{array}{l}0.0026^{*} \\
(0.001)\end{array}$ & $\begin{array}{c}0.0032 * * \\
(0.001)\end{array}$ & $\begin{array}{c}0.0023^{*} \\
(0.001)\end{array}$ \\
\hline Share Restrictions & $\begin{array}{l}0.0006 \\
(0.000)\end{array}$ & $\begin{array}{l}0.0004 \\
(0.000)\end{array}$ & $\begin{array}{l}0.0007 \\
(0.000)\end{array}$ & $\begin{array}{l}0.0005 \\
(0.000)\end{array}$ & $\begin{array}{l}0.0004 \\
(0.001)\end{array}$ & $\begin{array}{l}0.0005 \\
(0.000)\end{array}$ & $\begin{array}{l}0.0005 \\
(0.000)\end{array}$ & $\begin{array}{l}0.0005 \\
(0.000)\end{array}$ & $\begin{array}{l}0.0005 \\
(0.000)\end{array}$ & $\begin{array}{c}0.0009 * \\
(0.001)\end{array}$ \\
\hline Market & $\begin{array}{c}0.4343 * * * \\
(0.023)\end{array}$ & $\begin{array}{c}0.3834 * * * \\
(0.023)\end{array}$ & $\begin{array}{c}0.3992 * * * \\
(0.024)\end{array}$ & $\begin{array}{c}0.3834 * * * \\
(0.021)\end{array}$ & $\begin{array}{c}0.3877 * * * \\
(0.022)\end{array}$ & $\begin{array}{c}0.3926^{* * * *} \\
(0.023)\end{array}$ & $\begin{array}{c}0.4004 * * * \\
(0.023)\end{array}$ & $\begin{array}{c}0.3969 * * * \\
(0.023)\end{array}$ & $\begin{array}{c}0.3913 * * * \\
(0.023)\end{array}$ & $\begin{array}{c}0.4264 * * * \\
(0.026)\end{array}$ \\
\hline Market x Share Restrictions & $\begin{array}{c}0.0095^{*} \\
(0.006)\end{array}$ & $\begin{array}{c}0.0098^{*} \\
(0.005)\end{array}$ & $\begin{array}{c}0.0094 * \\
(0.005)\end{array}$ & $\begin{array}{c}0.0112^{* *} \\
(0.005)\end{array}$ & $\begin{array}{c}0.0110^{* * *} \\
(0.005)\end{array}$ & $\begin{array}{c}0.0100 * \\
(0.005)\end{array}$ & $\begin{array}{c}0.0093 * \\
(0.005)\end{array}$ & $\begin{array}{c}0.0089^{*} \\
(0.005)\end{array}$ & $\begin{array}{c}0.0097 * \\
(0.005)\end{array}$ & $\begin{array}{l}0.0087 \\
(0.006)\end{array}$ \\
\hline Neg Sent x Share Restrictions & $\begin{array}{r}-0.0007 \\
(0.001)\end{array}$ & $\begin{array}{l}-0.0005 \\
(0.001)\end{array}$ & $\begin{array}{l}-0.0008 \\
(0.001)\end{array}$ & $\begin{array}{r}-0.0005 \\
(0.001)\end{array}$ & $\begin{array}{r}-0.0004 \\
(0.001)\end{array}$ & $\begin{array}{l}-0.0005 \\
(0.001)\end{array}$ & $\begin{array}{l}-0.0006 \\
(0.001)\end{array}$ & $\begin{array}{l}-0.0007 \\
(0.001)\end{array}$ & $\begin{array}{l}-0.0005 \\
(0.001)\end{array}$ & $\begin{array}{c}-0.0013 * * \\
(0.001)\end{array}$ \\
\hline Constant & $\begin{array}{c}0.0061^{* * *} \\
(0.001)\end{array}$ & $\begin{array}{c}0.0063^{* * * *} \\
(0.001)\end{array}$ & $\begin{array}{c}0.0068^{* * *} \\
(0.001)\end{array}$ & $\begin{array}{c}0.0069^{* * *} \\
(0.001)\end{array}$ & $\begin{array}{c}0.0061^{* * *} \\
(0.001)\end{array}$ & $\begin{array}{c}0.0063^{* * *} * \\
(0.001)\end{array}$ & $\begin{array}{c}0.0062 * * * \\
(0.001)\end{array}$ & $\begin{array}{c}0.0062^{* * *} \\
(0.001)\end{array}$ & $\begin{array}{c}0.0064 * * * \\
(0.001)\end{array}$ & $\begin{array}{c}0.0067 * * * \\
(0.001)\end{array}$ \\
\hline Observations & 220,122 & 220,122 & 220,122 & 220,122 & 220,122 & 220,122 & 220,122 & 220,122 & 220,122 & 220,122 \\
\hline R-squared & 0.155 & 0.155 & 0.152 & 0.157 & 0.156 & 0.156 & 0.155 & 0.156 & 0.155 & 0.147 \\
\hline
\end{tabular}

The dependent variable is the monthly return of hedge fund $i$. On top of each column we indicate the portfolio of potentially mispriced stocks we consider in that specification. Portfolios are formed once per year using market equity, age, and volatility at the end of June of year $t$, and accounting data at the fiscal year-end of calendar year $t-1$. Portfolios are constructed based on NYSE decile breakpoints. Portfolio is the equally weighted monthly return of a given portfolio of stocks. Market is the value-weighted excess market return of all NYSE, AMEX, and NASDAQ stocks, which we obtain from Ken French's website. Neg Sent is a dummy variable that takes value equal to one during periods of negative sentiment, defined as in Baker and Wurgler (2007). Share Restrictions is the sum of the number of days in the lock up, redemption notice and payout periods, divided by 100 . All remaining variables, including the definition of firm characteristics used for the portfolio construction, are defined in the Appendix. We present ordinary least squares estimates with errors double clustered at the fund and time level and corrected for heteroscedasticity. $* * * * *, *$ denote significance at $1 \%, 5 \%$, and $10 \%$ levels, respectively. 


\section{Internet Appendix \\ (not for publication)}

Figure IA.1

\section{Average Cumulative Abnormal Returns of Fire Sale Stocks}

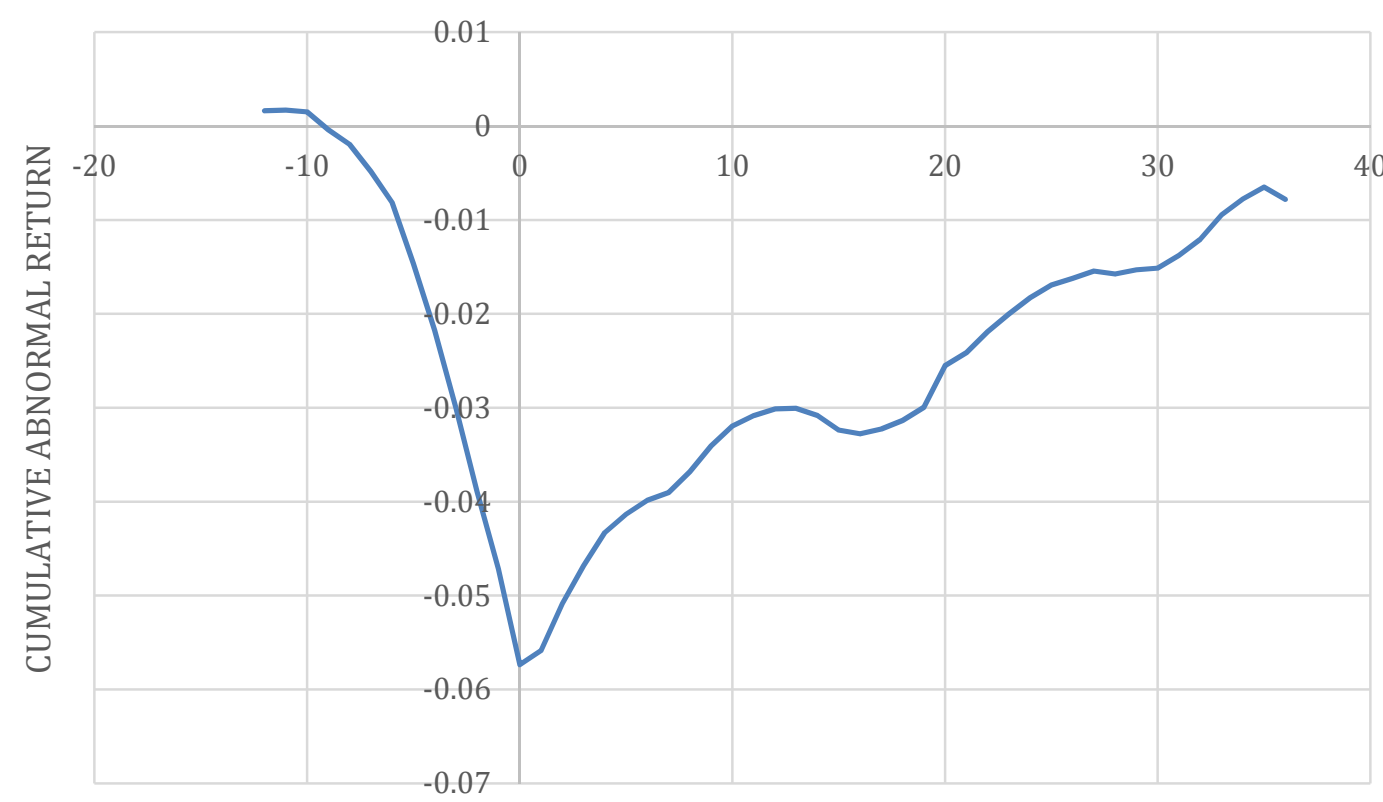

MONTHS FROM FIRE SALE EVENT

This figure presents the average cumulative abnormal returns of all fire sale stocks, defined as in Coval and Stafford (2007). In each period, we form a portfolio of fire sale stocks and calculate the equally-weighted average monthly abnormal returns of each portfolio. Cumulative average abnormal returns are monthly returns in excess of the equal-weighted average return of all stocks held by mutual funds at the start of the month. We start cumulating the abnormal returns 12 months before the fire sale event. The fire sale quarter is $t=0$. The sample period is $2004-2014$. 
Table IA.1

Closed- and Open-end Funds' Trades in Fire Sale Stocks: Further Robustness

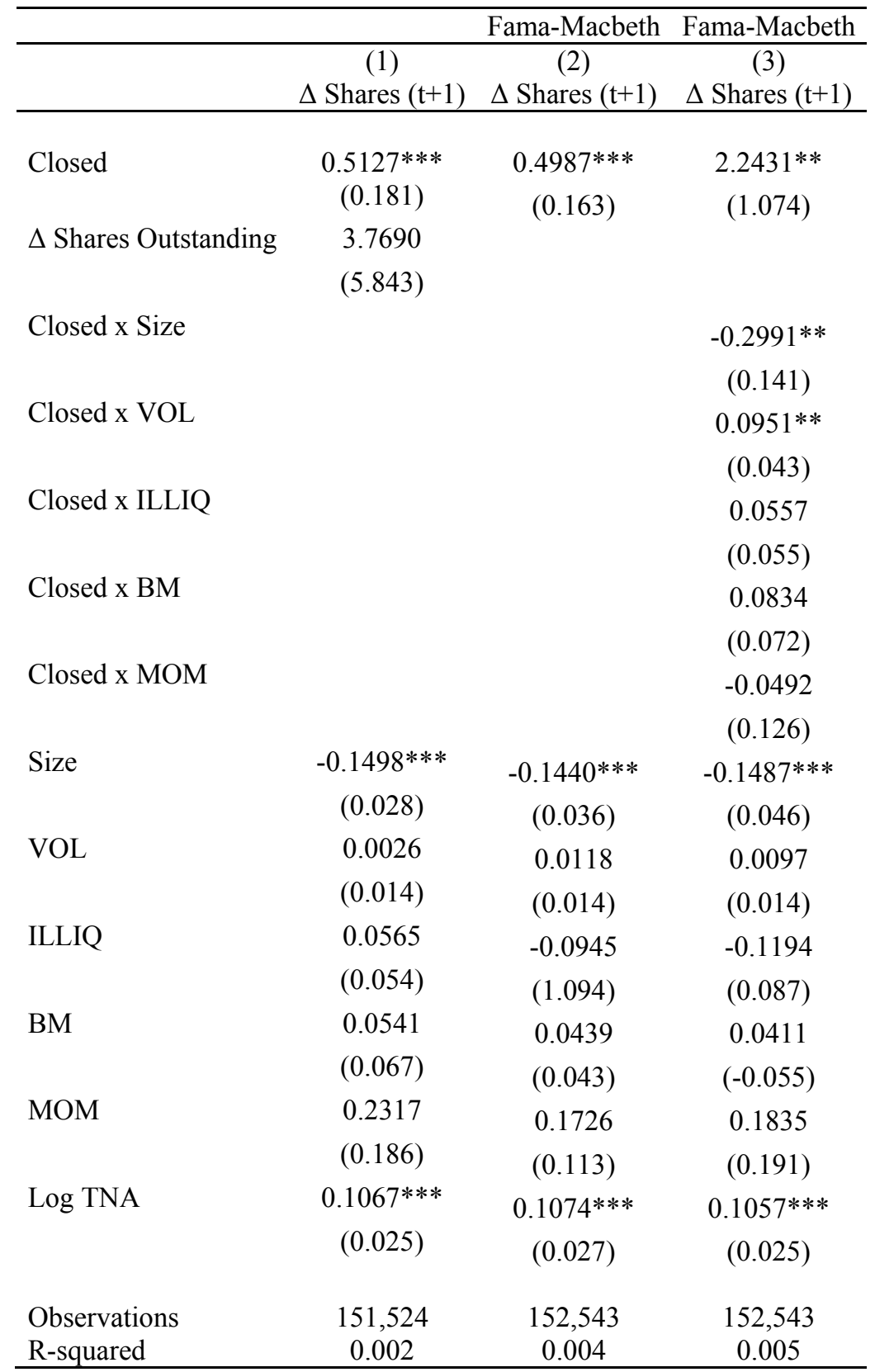

Column 1 reproduces column 4 of Table 4 controlling for the closed-end funds' change in (splitadjusted) shares outstanding, divided by the fund's number of shares outstanding at the beginning of the quarter, $\Delta$ Shrout. Column (2) and (3) reproduce the fire sale result using a Fama-Macbeth methodology; in column 3 we also include interactions of the dummy Closed with firm characteristics. The dependent variable is a fund's change in quarterly holdings in the quarter following the fire sale. All remaining variables are defined in the Appendix. All equations include a constant whose coefficients are not reported. Column 1 also include time fixed effects. In the ordinary least squares estimates in column 1, errors are double clustered at the fund and time level and corrected for heteroscedasticity. In columns 2 and 3, we report Newey-West standard errors, which allow for sixmonth correlation in error terms. $* * *, * * *$ denote significance at $1 \%, 5 \%$, and $10 \%$ levels, respectively. 
Table IA.2

Risk and Return of Fire Sale Stocks Sold and Non-Fire Sale Stocks Purchased by Non-Distressed Open-end Funds

\begin{tabular}{|c|c|c|c|c|c|c|c|c|}
\hline \multirow[b]{2}{*}{ Month } & \multicolumn{4}{|c|}{ Fire Sale Stocks Sold } & \multicolumn{4}{|c|}{ Stocks Purchased } \\
\hline & 25th Pctl & $\mathrm{AR}$ & 75th Pctl & CAR & 25th Pctl & $\mathrm{AR}$ & 75th Pctl & CAR \\
\hline 1 & -6.1242 & -0.0988 & 6.0287 & -0.0988 & -4.1312 & 0.2332 & 4.5126 & 0.2332 \\
\hline 2 & -6.4959 & 0.4428 & 6.6394 & 0.3439 & -4.2450 & 0.1849 & 4.4322 & 0.4181 \\
\hline 3 & -6.3964 & -0.3291 & 6.2406 & 0.0148 & -4.1097 & 0.0846 & 4.2184 & 0.5027 \\
\hline 4 & -6.3928 & 0.3681 & 6.8335 & 0.3829 & -4.2955 & 0.0540 & 4.3407 & 0.5567 \\
\hline 5 & -6.5079 & 0.2970 & 6.6624 & 0.6798 & -4.2719 & 0.1375 & 4.4468 & 0.6942 \\
\hline 6 & -7.0034 & -0.3142 & 6.3813 & 0.3656 & -4.1419 & 0.0140 & 4.1453 & 0.7082 \\
\hline 7 & -6.6753 & -0.2386 & 6.3792 & 0.1270 & -4.4397 & 0.1215 & 4.5901 & 0.8297 \\
\hline 8 & -6.0819 & 0.6488 & 6.8413 & 0.7758 & -4.5784 & 0.0588 & 4.6189 & 0.8885 \\
\hline 9 & -6.3028 & 0.3766 & 6.6319 & 1.1524 & -4.2726 & -0.0045 & 4.3868 & 0.8840 \\
\hline 10 & -6.1029 & 0.4503 & 6.5464 & 1.6027 & -4.5297 & 0.0559 & 4.6302 & 0.9398 \\
\hline 11 & -7.0935 & -0.1231 & 6.8909 & 1.4796 & -4.7236 & 0.1052 & 4.7968 & 1.0451 \\
\hline 12 & -6.3585 & 0.6203 & 6.9125 & 2.0999 & -5.1297 & -0.1022 & 5.0659 & 0.9429 \\
\hline
\end{tabular}

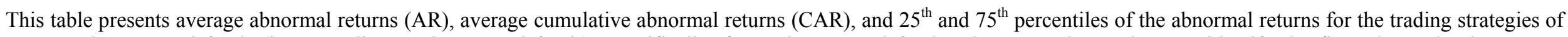

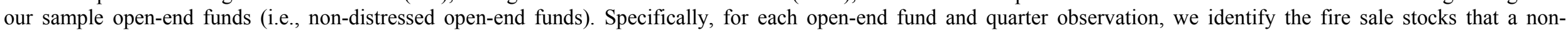
distressed open-end fund sold and the non-fire-sale stocks the open-end funds purchased, and compute the subsequent monthly abnormal return of these stocks. Returns are

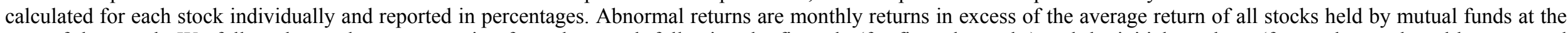

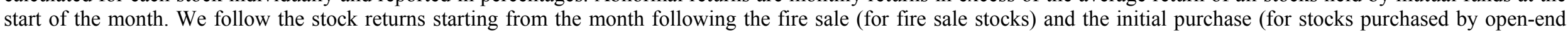
funds) up to 12 months later. The sample period is 2004-2014. 
Table IA.3

Closed-end Funds' Performance and Trading in Fire Sales Stocks

\begin{tabular}{lcc}
\hline & $(1)$ & $(2)$ \\
& Alpha & Alpha \\
\hline \multirow{2}{*}{ Net purchases } & $0.0692^{* *}$ & $0.0612^{* *}$ \\
& $(0.032)$ & $(0.031)$ \\
Fund ILLIQ & & $0.0435^{*}$ \\
& & $(0.024)$ \\
Observations & 772 & 772 \\
R-squared & 0.661 & 0.685 \\
\hline
\end{tabular}

The dependent variable is closed-end funds' performance defined as the monthly alpha (in \%) of the Cahart four-factor model, including the three Fama-French factors and the momentum factor and estimated for each fund over a 24-month rolling window. To avoid overlapping observations, we use each fund's alpha as of December at biennial frequency. The main variable of interest, Net purchases, is defined as the average of the change of the holdings of each fire sale stock during quarter $t+1$, computed using the stock beginning of quarter prices, divided by the fund's TNA at the beginning of the quarter, and multiplied by 100. For each fund, we take the average of Net purchases over the 24month period for which the alpha is estimated. Fund ILLIQ is the weighted average of the Amihud illiquidity measure of the stocks in the fund's portfolio; for each fund, we take the average over the 24month period during which the alpha is estimated. All equations include time fixed effects and a constant, whose coefficients are not reported. We present ordinary least squares estimates with errors double clustered at the fund and time level and corrected for heteroscedasticity. ***, **, * denote significance at $1 \%, 5 \%$, and $10 \%$ levels, respectively. 
Table IA.4

Closed- and Open-end Funds' Trades in Fire Sale Stocks under Different Market Conditions

\begin{tabular}{|c|c|c|c|c|}
\hline Dependent Variable: $\Delta$ Shares $(\mathrm{t}+1)$ & (1) & (2) & (3) & (4) \\
\hline Closed & $\begin{array}{c}0.4035^{* *} \\
(0.177)\end{array}$ & $\begin{array}{c}0.3835 * * \\
(0.194)\end{array}$ & $\begin{array}{c}0.3187 * * \\
(0.153)\end{array}$ & $\begin{array}{c}0.4842 * * \\
(0.203)\end{array}$ \\
\hline Closed x Aggflow & $\begin{array}{c}0.8957^{*} \\
(0.509)\end{array}$ & & & \\
\hline Aggflow & $\begin{array}{c}-0.1793 \\
(0.121)\end{array}$ & & & \\
\hline Closedx VIX & & $\begin{array}{l}0.0107 \\
(0.011)\end{array}$ & & \\
\hline VIX & & $\begin{array}{l}0.0003 \\
(0.004)\end{array}$ & & \\
\hline Closed x Crisis 1 & & & $\begin{array}{c}0.5883^{*} \\
(0.316)\end{array}$ & \\
\hline Crisis 1 & & & $\begin{array}{l}0.0615 \\
(0.070)\end{array}$ & \\
\hline Closed $\mathrm{x}$ Crisis 2 & & & & $\begin{array}{l}0.1147 \\
(0.232)\end{array}$ \\
\hline Crisis2 & & & & $\begin{array}{l}0.1421 \\
(0.095)\end{array}$ \\
\hline Log TNA & $\begin{array}{c}0.1013 * * * \\
(0.025)\end{array}$ & $\begin{array}{c}0.1029 * * * \\
(0.025)\end{array}$ & $\begin{array}{c}0.1027 * * * \\
(0.025)\end{array}$ & $\begin{array}{c}0.1038 * * * \\
(0.025)\end{array}$ \\
\hline Size & $\begin{array}{c}-0.1381 * * * \\
(0.027)\end{array}$ & $\begin{array}{c}-0.1408 * * * \\
(0.027)\end{array}$ & $\begin{array}{c}-0.1368^{* * *} \\
(0.027)\end{array}$ & $\begin{array}{c}-0.1367 * * * \\
(0.027)\end{array}$ \\
\hline VOL & $\begin{array}{l}0.0002 \\
(0.013)\end{array}$ & $\begin{array}{l}0.0001 \\
(0.014)\end{array}$ & $\begin{array}{l}0.0012 \\
(0.013)\end{array}$ & $\begin{array}{l}-0.0006 \\
(0.013)\end{array}$ \\
\hline ILLIQ & $\begin{array}{l}0.0574 \\
(0.054)\end{array}$ & $\begin{array}{l}0.0572 \\
(0.054)\end{array}$ & $\begin{array}{l}0.0573 \\
(0.054)\end{array}$ & $\begin{array}{l}0.0571 \\
(0.054)\end{array}$ \\
\hline $\mathrm{BM}$ & $\begin{array}{l}0.0625 \\
(0.069)\end{array}$ & $\begin{array}{l}0.0661 \\
(0.068)\end{array}$ & $\begin{array}{l}0.0740 \\
(0.068)\end{array}$ & $\begin{array}{l}0.0639 \\
(0.068)\end{array}$ \\
\hline MOM & $\begin{array}{l}0.1005 \\
(0.165)\end{array}$ & $\begin{array}{l}0.1087 \\
(0.168)\end{array}$ & $\begin{array}{l}0.1553 \\
(0.157)\end{array}$ & $\begin{array}{l}0.1704 \\
(0.178)\end{array}$ \\
\hline $\begin{array}{l}\text { Observations } \\
\text { R-squared }\end{array}$ & $\begin{array}{c}152,543 \\
0.001\end{array}$ & $\begin{array}{c}152,543 \\
0.001\end{array}$ & $\begin{array}{c}152,543 \\
0.001\end{array}$ & $\begin{array}{c}152,543 \\
0.001\end{array}$ \\
\hline
\end{tabular}

We compare the change in holdings of closed- and open-end funds around fire sale events and examine how the effects of the closed-end fund structure vary across different market conditions, captured by the following proxies: AggFlow measuring the aggregate flows in open-end funds, defined as the sum of all the open-end fund flows, divided by the aggregate open-end fund assets at the beginning of the quarter; the VIX index, capturing aggregate market uncertainty; the Crisis 1 dummy that takes value equal to 1 from the third quarter of 2007 to the fourth quarter of 2009; and the Crisis 2 dummy that takes value equal to 1 from the third quarter of 2008 to the fourth quarter of 2009. Quarter $t$ is the quarter of the fire sale identified as in Coval and Stafford (2007). The dependent variable is a fund's change in quarterly holdings $\left(\Delta \operatorname{shares}(t+1)_{i, s, t}\right)$ in the quarter following the fire sale, divided by the firm's number of shares outstanding at the beginning of the quarter. We divide $\Delta$ shares $(t+1)_{i, s, t}$ by the standard deviation of all $\Delta$ shares $(t+1)_{f, i, s}$ of closed- and open-end funds (including non fire sale stocks) during the sample period. All remaining variables are defined in the Appendix. All equations include time fixed effects and a constant whose coefficients are not reported. We present ordinary least squares estimates with errors double clustered at the fund and time level and corrected for heteroscedasticity. $* * *, * *, *$ denote significance at $1 \%, 5 \%$, and $10 \%$ levels, respectively. 
Table IA.5

Hedge Funds' Trades in Fire Sale Stocks: Matching Sample

\begin{tabular}{|c|c|c|c|c|c|}
\hline & $\begin{array}{c}(1) \\
\Delta \text { Shares }(t-2) \\
\end{array}$ & $\begin{array}{c}(2) \\
\Delta \text { Shares (t-1) }\end{array}$ & $\begin{array}{c}(3) \\
\Delta \text { Shares }(\mathrm{t}) \\
\end{array}$ & $\begin{array}{c}(4) \\
\Delta \text { Shares }(t+1) \\
\end{array}$ & $\begin{array}{c}(5) \\
\Delta \text { Shares }(t+2)\end{array}$ \\
\hline Share Restrictions & $\begin{array}{l}0.0110 \\
(0.021)\end{array}$ & $\begin{array}{l}0.0155 \\
(0.016)\end{array}$ & $\begin{array}{c}0.0651 * * \\
(0.032)\end{array}$ & $\begin{array}{l}0.0218 \\
(0.023)\end{array}$ & $\begin{array}{l}0.0190 \\
(0.017)\end{array}$ \\
\hline ILLIQ & $\begin{array}{l}-0.0007 \\
(0.011)\end{array}$ & $\begin{array}{c}-0.0088 * * * \\
(0.003)\end{array}$ & $\begin{array}{c}-0.0148 * * * \\
(0.005)\end{array}$ & $\begin{array}{c}-0.0160 * * * \\
(0.003)\end{array}$ & $\begin{array}{c}-0.0151 * * * \\
(0.001)\end{array}$ \\
\hline MOM & $\begin{array}{l}0.0058 \\
(0.106)\end{array}$ & $\begin{array}{l}0.0351 \\
(0.088)\end{array}$ & $\begin{array}{c}0.1187^{* *} \\
(0.059)\end{array}$ & $\begin{array}{l}-0.0661 \\
(0.071)\end{array}$ & $\begin{array}{l}0.0032 \\
(0.059)\end{array}$ \\
\hline Size & $\begin{array}{c}-0.1908 * * * \\
(0.020)\end{array}$ & $\begin{array}{c}-0.1752 * * * \\
(0.015)\end{array}$ & $\begin{array}{c}-0.1901 * * * \\
(0.023)\end{array}$ & $\begin{array}{c}-0.2066 * * * \\
(0.021)\end{array}$ & $\begin{array}{c}-0.1802 * * * \\
(0.015)\end{array}$ \\
\hline Vol & $\begin{array}{c}0.0312 * * * \\
(0.005)\end{array}$ & $\begin{array}{c}0.0219 * * * \\
(0.004)\end{array}$ & $\begin{array}{c}0.0227 * * * \\
(0.006)\end{array}$ & $\begin{array}{c}0.0288 * * * \\
(0.007)\end{array}$ & $\begin{array}{c}0.0210 * * * \\
(0.005)\end{array}$ \\
\hline $\mathrm{BM}$ & $\begin{array}{l}0.0101 \\
(0.007)\end{array}$ & $\begin{array}{l}-0.0011 \\
(0.004)\end{array}$ & $\begin{array}{l}-0.0100 \\
(0.007)\end{array}$ & $\begin{array}{l}-0.0023 \\
(0.005)\end{array}$ & $\begin{array}{l}0.0013 \\
(0.005)\end{array}$ \\
\hline Log TNA & $\begin{array}{c}0.0279 * * \\
(0.014)\end{array}$ & $\begin{array}{c}0.0234 * * \\
(0.009)\end{array}$ & $\begin{array}{c}0.0333^{*} \\
(0.018)\end{array}$ & $\begin{array}{c}0.0228 * * \\
(0.011)\end{array}$ & $\begin{array}{c}0.0212 * * \\
(0.010)\end{array}$ \\
\hline $\begin{array}{l}\text { Observations } \\
\text { R-squared }\end{array}$ & $\begin{array}{c}44,246 \\
0.053\end{array}$ & $\begin{array}{c}44,242 \\
0.053\end{array}$ & $\begin{array}{c}44,713 \\
0.055\end{array}$ & $\begin{array}{c}44,121 \\
0.051\end{array}$ & $\begin{array}{c}44,780 \\
0.051\end{array}$ \\
\hline
\end{tabular}

We explore how the change in holdings of hedge funds varies around fire sale events in a matched sample of hedge funds with high and low share restrictions. Share Restrictions is the sum of the number of days in the lock up, redemption notice and payout periods, divided by 100 . We match each hedge fund with share restrictions above the median with a hedge fund with share restrictions below the median, which is within $70-130 \%$ of the hedge fund's size and that minimizes the sum of the absolute percentage differences in TNA, number of stocks, and exposure to the Fung-Hsieh factors, estimated over a 24-month rolling window. The matching is performed with replacement. Quarter $t$ is the quarter of the fire sale identified as in Coval and Stafford (2007). The dependent variable is a fund's change in quarterly holdings $\left(\Delta \operatorname{shares}(t+k)_{i, s, t}\right)$ in the quarters preceding, during or following the fire sale, as indicated on top of each column, divided by the firm's number of share outstanding at the beginning of the quarter. We divide $\Delta$ shares $(t+k)_{i, s, t}$ by the standard deviation of all $\Delta$ shares $(t+k)_{i, s, t}$ of hedge funds (including non fire sale stocks) during the sample period. All remaining variables are defined in the Appendix. All equations include time fixed effects and a constant whose coefficients are not reported. We present ordinary least squares estimates with errors double clustered at the fund and time level and corrected for heteroscedasticity. ***, **, * denote significance at $1 \%, 5 \%$, and $10 \%$ levels, respectively. 
Table IA.6

Hedge Funds' Trades in Placebo Fire Sale Stocks

Panel A. Matched Stocks

\begin{tabular}{|c|c|c|c|c|c|}
\hline & $\begin{array}{c}(1) \\
\Delta \text { Shares }(\mathrm{t}-2)\end{array}$ & $\begin{array}{c}(2) \\
\Delta \text { Shares }(\mathrm{t}-1)\end{array}$ & $\begin{array}{c}(3) \\
\Delta \text { Shares (t) }\end{array}$ & $\begin{array}{c}(4) \\
\Delta \text { Shares }(t+1)\end{array}$ & $\begin{array}{c}(5) \\
\Delta \text { Shares }(t+2)\end{array}$ \\
\hline Share Restrictions & $\begin{array}{l}0.0162 \\
(0.023)\end{array}$ & $\begin{array}{l}0.0122 \\
(0.018)\end{array}$ & $\begin{array}{l}0.0298 \\
(0.029)\end{array}$ & $\begin{array}{l}0.0223 \\
(0.022)\end{array}$ & $\begin{array}{l}0.0178 \\
(0.021)\end{array}$ \\
\hline ILLIQ & $\begin{array}{c}-0.0161 * * * \\
(0.002)\end{array}$ & $\begin{array}{c}-0.0086^{* * *} \\
(0.003)\end{array}$ & $\begin{array}{c}-0.0133 * * * \\
(0.003)\end{array}$ & $\begin{array}{c}-0.0058 * \\
(0.003)\end{array}$ & $\begin{array}{c}-0.0129 * * * \\
(0.002)\end{array}$ \\
\hline MOM & $\begin{array}{l}0.1006 \\
(0.084)\end{array}$ & $\begin{array}{l}0.0435 \\
(0.066)\end{array}$ & $\begin{array}{l}0.0203 \\
(0.059)\end{array}$ & $\begin{array}{c}-0.0947^{*} \\
(0.049)\end{array}$ & $\begin{array}{l}-0.0635 \\
(0.065)\end{array}$ \\
\hline Size & $\begin{array}{c}-0.1760 * * * \\
(0.016)\end{array}$ & $\begin{array}{c}-0.1544 * * * \\
(0.016)\end{array}$ & $\begin{array}{c}-0.1792 * * * \\
(0.021)\end{array}$ & $\begin{array}{c}-0.1741 * * * \\
(0.016)\end{array}$ & $\begin{array}{c}-0.1812 * * * \\
(0.016)\end{array}$ \\
\hline VOL & $\begin{array}{c}0.0295 * * * \\
(0.004)\end{array}$ & $\begin{array}{c}0.0226 * * * \\
(0.003)\end{array}$ & $\begin{array}{c}0.0267 * * * \\
(0.005)\end{array}$ & $\begin{array}{c}0.0235^{* * *} \\
(0.004)\end{array}$ & $\begin{array}{c}0.0211 * * * \\
(0.004)\end{array}$ \\
\hline $\mathrm{BM}$ & $\begin{array}{c}0.0124 * * \\
(0.006)\end{array}$ & $\begin{array}{l}-0.0022 \\
(0.003)\end{array}$ & $\begin{array}{l}0.0049 \\
(0.005)\end{array}$ & $\begin{array}{c}0.0085 * * \\
(0.004)\end{array}$ & $\begin{array}{c}-0.0038^{* *} \\
(0.002)\end{array}$ \\
\hline Log TNA & $\begin{array}{c}0.0319 * * * \\
(0.012)\end{array}$ & $\begin{array}{c}0.0209 * * \\
(0.009)\end{array}$ & $\begin{array}{c}0.0231 * * \\
(0.011)\end{array}$ & $\begin{array}{c}0.0170 * \\
(0.009)\end{array}$ & $\begin{array}{c}0.0237 * * * \\
(0.009)\end{array}$ \\
\hline Observations & 59,805 & 58,091 & 58,734 & 59,914 & 59,923 \\
\hline R-squared & 0.043 & 0.043 & 0.043 & 0.044 & 0.045 \\
\hline
\end{tabular}


Panel B. Discretionary Sales

\begin{tabular}{|c|c|c|c|c|c|}
\hline & $\begin{array}{c}(1) \\
\Delta \text { Shares }(\mathrm{t}-2) \\
\end{array}$ & $\begin{array}{c}(2) \\
\Delta \text { Shares }(\mathrm{t}-1) \\
\end{array}$ & $\begin{array}{c}(3) \\
\Delta \text { Shares }(\mathrm{t}) \\
\end{array}$ & $\begin{array}{c}4) \\
\Delta \text { Shares }(t+1) \\
\end{array}$ & $\begin{array}{c}(5) \\
\Delta \text { Shares }(t+2)\end{array}$ \\
\hline Share Restrictions & $\begin{array}{l}0.0250 \\
(0.022)\end{array}$ & $\begin{array}{l}0.0330 \\
(0.023)\end{array}$ & $\begin{array}{l}0.0034 \\
(0.024)\end{array}$ & $\begin{array}{l}0.0026 \\
(0.017)\end{array}$ & $\begin{array}{l}0.0033 \\
(0.020)\end{array}$ \\
\hline ILLIQ & $\begin{array}{c}-0.0105 * * * \\
(0.002)\end{array}$ & $\begin{array}{c}-0.0139 * * * \\
(0.003)\end{array}$ & $\begin{array}{c}-0.0147 * * * \\
(0.002)\end{array}$ & $\begin{array}{c}-0.0083 * * * \\
(0.002)\end{array}$ & $\begin{array}{c}-0.0089 * * * \\
(0.002)\end{array}$ \\
\hline MOM & $\begin{array}{l}0.0548 \\
(0.078)\end{array}$ & $\begin{array}{l}0.0920 \\
(0.074)\end{array}$ & $\begin{array}{l}-0.0345 \\
(0.066)\end{array}$ & $\begin{array}{l}-0.0523 \\
(0.098)\end{array}$ & $\begin{array}{l}-0.0882 \\
(0.081)\end{array}$ \\
\hline Size & $\begin{array}{c}-0.1711 * * * \\
(0.013)\end{array}$ & $\begin{array}{c}-0.1848 * * * \\
(0.016)\end{array}$ & $\begin{array}{c}-0.1819 * * * \\
(0.018)\end{array}$ & $\begin{array}{c}-0.1621 * * * \\
(0.017)\end{array}$ & $\begin{array}{c}-0.1639 * * * \\
(0.013)\end{array}$ \\
\hline VOL & $\begin{array}{c}0.0314 * * * \\
(0.004)\end{array}$ & $\begin{array}{c}0.0277 * * * \\
(0.004)\end{array}$ & $\begin{array}{c}0.0288 * * * \\
(0.006)\end{array}$ & $\begin{array}{c}0.0272 * * * \\
(0.005)\end{array}$ & $\begin{array}{c}0.0272 * * * \\
(0.004)\end{array}$ \\
\hline BM & $\begin{array}{l}0.0056 \\
(0.004)\end{array}$ & $\begin{array}{c}0.0077 * * \\
(0.004)\end{array}$ & $\begin{array}{l}0.0052 \\
(0.003)\end{array}$ & $\begin{array}{l}0.0081^{*} \\
(0.004)\end{array}$ & $\begin{array}{c}0.0100 * * \\
(0.005)\end{array}$ \\
\hline Log TNA & $\begin{array}{c}0.0295 * * \\
(0.012)\end{array}$ & $\begin{array}{c}0.0415 * * * \\
(0.015)\end{array}$ & $\begin{array}{c}0.0383 * * \\
(0.015)\end{array}$ & $\begin{array}{c}0.0314 * * * \\
(0.011)\end{array}$ & $\begin{array}{c}0.0316^{* * *} \\
(0.011)\end{array}$ \\
\hline $\begin{array}{l}\text { Observations } \\
\text { R-squared }\end{array}$ & $\begin{array}{c}69,175 \\
0.047\end{array}$ & $\begin{array}{c}69,578 \\
0.047\end{array}$ & $\begin{array}{c}70,166 \\
0.046\end{array}$ & $\begin{array}{c}69,339 \\
0.046\end{array}$ & $\begin{array}{c}69,200 \\
0.043\end{array}$ \\
\hline
\end{tabular}

We consider hedge funds' trading in different sets of stocks. In Panel A, we consider stocks that match each fire sale stock in quarter $t$, the quarter of the fire sale, identified as in Coval and Stafford (2007). The matching is performed with replacement and requires that the matched stock is in the same twodigit industry, within $70-130 \%$ of size of the fire sale stock, and that minimizes the absolute percentage differences in size and book to market ratio. In Panel B, we consider hedge funds' trading in stocks that are subject to large discretionary sales. Following Coval and Stafford (2007), for each stock, we define Disc Sales $_{s, t}=\sum_{i} \Delta$ Hold $_{i, s, t} /$ AvgVolume $_{s, t-12: t-6}$, that is, the ratio of the change in shares held by non-distressed open-end funds relative to the stock's trading volume. Stocks with Disc Sales below the $10^{\text {th }}$ percentile are considered to be stocks with large discretionary sales. Share Restrictions is the sum of the number of days in the lock up, redemption notice and payout periods, divided by 100 . The dependent variable is a fund's change in quarterly holdings $\left(\Delta \operatorname{shares}(t+k)_{i, s, t}\right)$ in the quarters preceding, during or following the fire sale or discretionary sale, as indicated on top of each column, divided by the firm's number of shares outstanding at the beginning of the quarter. We divide $\Delta$ shares $(t+k)_{i, s, t}$ by the standard deviation of all $\Delta$ shares $(t+k)_{i, s, t}$ of hedge funds (including non fire sale stocks) during the sample period. All remaining variables are defined in the Appendix. All equations include time fixed effects and a constant whose coefficients are not reported. We present ordinary least squares estimates with errors double clustered at the fund and time level and corrected for heteroscedasticity. $* * * * *, *$ denote significance at $1 \%, 5 \%$, and $10 \%$ levels, respectively. 
Table IA. 7

Hedge Funds' Trades in Fire Sale Stocks: Further Robustness Checks

\begin{tabular}{|c|c|c|c|}
\hline & $\begin{array}{c}(1) \\
\Delta \text { Shares }(\mathrm{t})\end{array}$ & $\begin{array}{c}(2) \\
\Delta \text { Shares }(\mathrm{t})\end{array}$ & $\begin{array}{c}(3) \\
\Delta \text { Shares }(\mathrm{t})\end{array}$ \\
\hline Share Restrictions & $\begin{array}{c}0.0820 * \\
(0.045)\end{array}$ & $\begin{array}{c}0.0983 * * \\
(0.042)\end{array}$ & $\begin{array}{c}0.0968 * * \\
(0.043)\end{array}$ \\
\hline Size & $\begin{array}{c}-0.2270 * * * \\
(0.026)\end{array}$ & $\begin{array}{c}-0.2179 * * * \\
(0.027)\end{array}$ & $\begin{array}{c}-0.2153 * * * \\
(0.027)\end{array}$ \\
\hline Vol & $\begin{array}{c}0.0254 * * * \\
(0.007)\end{array}$ & $\begin{array}{c}0.0265 * * * \\
(0.007)\end{array}$ & $\begin{array}{c}0.0269 * * * \\
(0.007)\end{array}$ \\
\hline ILLIQ & $\begin{array}{c}-0.0227 * * * \\
(0.009)\end{array}$ & $\begin{array}{c}-0.0238 * * * \\
(0.009)\end{array}$ & $\begin{array}{c}-0.0240 * * * \\
(0.009)\end{array}$ \\
\hline $\mathrm{BM}$ & $\begin{array}{l}-0.0033 \\
(0.006)\end{array}$ & $\begin{array}{l}-0.0032 \\
(0.006)\end{array}$ & $\begin{array}{l}-0.0030 \\
(0.006)\end{array}$ \\
\hline MOM & $\begin{array}{l}-0.0025 \\
(0.065)\end{array}$ & $\begin{array}{l}-0.0040 \\
(0.065)\end{array}$ & $\begin{array}{l}-0.0020 \\
(0.066)\end{array}$ \\
\hline Log TNA & $\begin{array}{c}0.0465 * * \\
(0.021)\end{array}$ & $\begin{array}{c}0.0353 * * \\
(0.017)\end{array}$ & $\begin{array}{c}0.0334^{*} \\
(0.017)\end{array}$ \\
\hline Annual fee & $\begin{array}{l}14.9052 \\
(12.649)\end{array}$ & & \\
\hline Incentive fee & $\begin{array}{l}1.3846 \\
(1.922)\end{array}$ & & \\
\hline High watermark & $\begin{array}{c}0.5467 * * \\
(0.248)\end{array}$ & & \\
\hline Min inv & & $\begin{array}{l}-0.0000 \\
(0.000)\end{array}$ & \\
\hline Leveraged & & & $\begin{array}{l}0.1561 \\
(0.194)\end{array}$ \\
\hline Observations & 58,638 & 58,447 & 58,813 \\
\hline R-squared & 0.063 & 0.061 & 0.061 \\
\hline
\end{tabular}

This table reports further robustness checks for the tests on hedge funds' trading in fire sales stocks. Share Restrictions is the sum of the number of days in the lock up, redemption notice and payout periods, divided by 100 . Quarter $t$ is the quarter of the fire sale identified as in Coval and Stafford (2007). The dependent variable is a fund's change in quarterly holdings $\left(\Delta \operatorname{shares}(t)_{i, s, t}\right)$ in the quarter of the fire sale, divided by the firm's number of share outstanding at the beginning of the quarter. We divide $\Delta$ shares $(t)_{i, s, t}$ by the standard deviation of all $\Delta$ shares $(t)_{i, s, t}$ of hedge funds (including non fire sale stocks) during the sample period. All remaining variables are defined in the Appendix. All equations include time fixed effects and a constant whose coefficients are not reported. We present ordinary least squares estimates with errors double clustered at the fund and time level and corrected for heteroscedasticity. $* * *, * *, *$ denote significance at $1 \%, 5 \%$, and $10 \%$ levels, respectively. 
Table IA.8

Hedge Funds' Exposure to Aggregate Mispricing: Additional Robustness

\begin{tabular}{|c|c|c|c|c|c|c|c|}
\hline & (1) & (2) & (3) & (4) & (5) & (6) & (7) \\
\hline Dependent & \multicolumn{6}{|c|}{ Monthly Return } & \\
\hline & & & & $\begin{array}{c}\text { Fung and } \\
\text { Hsieh } \\
\text { Factors } \\
\end{array}$ & Michigan & $\mathrm{HJ}$ & \\
\hline Small x Neg & $0.0229 * * *$ & $0.0208 * * *$ & $0.0209 * * *$ & $0.0191 * * *$ & $0.0118 * *$ & & \\
\hline & $(0.007)$ & $(0.006)$ & $(0.006)$ & $(0.006)$ & $(0.005)$ & & \\
\hline $\begin{array}{l}\text { UMO x Share } \\
\text { Restrictions }\end{array}$ & & & & & & $\begin{array}{c}0.0077 * * \\
(0.004)\end{array}$ & \\
\hline $\begin{array}{l}\text { Small x Share } \\
\text { Restrictions }\end{array}$ & $\begin{array}{l}-0.0094 \\
(0.007)\end{array}$ & $\begin{array}{l}-0.0087 \\
(0.007)\end{array}$ & $\begin{array}{l}-0.0087 \\
(0.007)\end{array}$ & $\begin{array}{l}-0.0076 \\
(0.007)\end{array}$ & $\begin{array}{l}0.0026 \\
(0.004)\end{array}$ & & \\
\hline Small x Neg & $-0.1220^{* *}$ & $-0.0990 * *$ & $-0.0952 * *$ & $-0.0916^{* *}$ & 0.0114 & & \\
\hline & $(0.056)$ & $(0.042)$ & $(0.041)$ & $(0.043)$ & $(0.048)$ & & \\
\hline Small & $\begin{array}{l}0.1993 * * * \\
(0.052)\end{array}$ & $\begin{array}{l}0.2084 * * * \\
(0.041)\end{array}$ & $\begin{array}{c}0.2065 * * * \\
(0.039)\end{array}$ & $\begin{array}{c}0.1998 * * * \\
(0.043)\end{array}$ & $\begin{array}{c}0.1113 * * * \\
(0.038)\end{array}$ & & \\
\hline Neg Sent & $\begin{array}{c}0.0025^{*} \\
(0.001)\end{array}$ & $\begin{array}{c}0.0018^{*} \\
(0.001)\end{array}$ & $\begin{array}{l}0.0017 \\
(0.001)\end{array}$ & $\begin{array}{l}0.0004 \\
(0.001)\end{array}$ & $\begin{array}{c}-0.0033^{* *} \\
(0.001)\end{array}$ & & $\begin{array}{l}-1.7287 \\
(2.731)\end{array}$ \\
\hline UMO & & & & & & $\begin{array}{c}-0.0268 \\
(0.021)\end{array}$ & \\
\hline Share & 0.0007 & $0.0007 *$ & 0.0007 & 0.0005 & 0.0001 & -0.0001 & $-0.7264^{*}$ \\
\hline $\operatorname{Re}$ & $(0.000)$ & $(0.000)$ & $(0.000)$ & $(0.000)$ & $(0.000)$ & $(0.000)$ & $(0.390)$ \\
\hline Market & $\begin{array}{c}0.4325 * * * \\
(0.023)\end{array}$ & $\begin{array}{c}0.4672 * * * \\
(0.022)\end{array}$ & $\begin{array}{c}0.4881 * * * \\
(0.037)\end{array}$ & $\begin{array}{c}0.4840 * * * \\
(0.039)\end{array}$ & $\begin{array}{c}0.4217 * * * \\
(0.017)\end{array}$ & $\begin{array}{c}0.3501 * * * \\
(0.020)\end{array}$ & \\
\hline Market x Share & $0.0093 *$ & 0.0081 & 0.0094 & 0.0095 & $0.0087 * * *$ & $0.0097 * *$ & \\
\hline & $(0.006)$ & $(0.006)$ & $(0.007)$ & $(0.007)$ & $(0.002)$ & $(0.004)$ & \\
\hline PS LIQ & $\begin{array}{l}0.0207 \\
(0.016)\end{array}$ & $\begin{array}{c}0.0108 \\
(0.016)\end{array}$ & $\begin{array}{c}0.0102 \\
(0.017)\end{array}$ & $\begin{array}{c}0.0136 \\
(0.018)\end{array}$ & $\begin{array}{c}0.0228 \\
(0.016)\end{array}$ & $\begin{array}{c}0.0180 \\
(0.017)\end{array}$ & \\
\hline PS LIQ x Share & $0.0046^{*}$ & $0.0046^{*}$ & $0.0045^{*}$ & 0.0039 & 0.0030 & $0.0032 *$ & \\
\hline & $(0.003)$ & $(0.003)$ & $(0.002)$ & $(0.002)$ & $(0.002)$ & $(0.002)$ & \\
\hline MOM & & $\begin{array}{c}0.0933 * * * \\
(0.020)\end{array}$ & $\begin{array}{c}0.0953 * * * \\
(0.019)\end{array}$ & $\begin{array}{c}0.0916^{* * * *} \\
(0.020)\end{array}$ & & & \\
\hline MOM x Share & & -0.0033 & -0.0031 & -0.0035 & & & \\
\hline Restrictions & & $(0.003)$ & $(0.003)$ & $(0.003)$ & & & \\
\hline $\begin{array}{l}\text { Market x Neg } \\
\text { sent }\end{array}$ & & & $\begin{array}{c}-0.0327 \\
(0.037)\end{array}$ & & & & \\
\hline $\begin{array}{l}\text { Market x Neg } \\
\text { sent x Share } \\
\text { Restrictions }\end{array}$ & & & -0.0022 & & & & \\
\hline $\begin{array}{l}\text { Neg sent } x \text { Share } \\
\text { Restrictions }\end{array}$ & $\begin{array}{c}-0.0009 \\
(0.001)\end{array}$ & $\begin{array}{c}-0.0009 * \\
(0.001)\end{array}$ & $\begin{array}{c}(0.005) \\
-0.0009 * \\
(0.001)\end{array}$ & $\begin{array}{r}-0.0006 \\
(0.000)\end{array}$ & $\begin{array}{c}-0.0003 * \\
(0.000)\end{array}$ & & $\begin{array}{c}1.1619 * * \\
(0.551)\end{array}$ \\
\hline Constant & $\begin{array}{c}0.0059 * * * \\
(0.001)\end{array}$ & $\begin{array}{c}0.0054 * * * \\
(0.001)\end{array}$ & $\begin{array}{c}0.0054 * * * \\
(0.001)\end{array}$ & $\begin{array}{l}0.0055^{*} \\
(0.003)\end{array}$ & $\begin{array}{c}0.0082 * * * \\
(0.001)\end{array}$ & $\begin{array}{c}0.0079 * * * \\
(0.001)\end{array}$ & $\begin{array}{l}1.2663 \\
(1.377)\end{array}$ \\
\hline
\end{tabular}




$\begin{array}{lccccccc}\text { Observations } & 220,122 & 220,122 & 220,122 & 220,122 & 220,122 & 220,122 & 13,085 \\ \text { R-squared } & 0.156 & 0.162 & 0.163 & 0.163 & 0.155 & 0.171 & 0.000 \\ \text { Fung and Hsieh } & \text { No } & \text { No } & \text { No } & \text { Yes } & \text { No } & \text { No } & \text { No } \\ \text { Factors } & & & & & & \end{array}$

In columns 1 to 6 , the dependent variable is the monthly return of hedge fund $i$. Small is the equally weighted monthly return of the portfolio of small stocks. The portfolio is formed once per year using market equity at the end of June of year $t$ and constructed using NYSE decile breakpoints. Stocks with market capitalization below this breakpoint are considered small. Market is the value-weighted excess market return of all NYSE, AMEX, and NASDAQ stocks, which we obtain from Ken French's website. In columns 1 to 4, Neg Sent is a dummy variable that takes value equal to one during periods of negative sentiment, defined as in Baker and Wurgler (2007). In column 5, Neg Sent is a dummy variable that takes value equal to one when the index of consumer sentiment compiled by the University of Michigan Survey Research Center is below the median. PS LIQ is the liquidity factor of Pastor and Stambaugh (2003). In column 6, UMO is the underpriced minus overpriced factor of Hirshleifer and Jiang (2010). Mom is the return of the momentum portfolio from Ken French's website. In column 4, we control for the eight hedge fund factors of Fung and Hsieh (2004). Share Restrictions is the sum of the number of days in the lock up, redemption notice and payout periods, divided by 100 . All remaining variables are defined in the Appendix. In column 7, the dependent variable is the quarterly percentage change in hedge fund $i$ 's total portfolio weight in small stocks, computed as the proportion of the portfolio held in small stocks using beginning-of-quarter stock prices. We present ordinary least squares estimates with errors double clustered at the fund and time level and corrected for heteroscedasticity. $* * *, * *, *$ denote significance at $1 \%, 5 \%$, and $10 \%$ levels, respectively. 